\begin{abstract}
UNIVERSIDADE DE SÃO PAULO
FACULDADE DE FILOSOFIA, LETRAS E CIÊNCIAS HUMANAS DEPARTAMENTO DE LETRAS ORIENTAIS

PROGRAMA DE PÓS-GRADUAÇÃO EM ESTUDOS JUDAICOS E ÁRABES
\end{abstract}

MATEUS DOMINGUES DA SILVA

A CRÍTICA AO PERIPATETISMO NO LIVRO DA SABEDORIA DA ILUMINAÇÃO DE SUHRAWARDİ

VERSÃO CORRIGIDA

SÃO PAULO

2013 
UNIVERSIDADE DE SÃO PAULO

FACULDADE DE FILOSOFIA, LETRAS E CIÊNCIAS HUMANAS

DEPARTAMENTO DE LETRAS ORIENTAIS

PROGRAMA DE PÓS-GRADUAÇÃO EM ESTUDOS JUDAICOS E ÁRABES

ÁREA DE CONCENTRAÇÃO EM ESTUDOS ÁRABES

\section{A CRÍTICA AO PERIPATETISMO NO LIVRO DA SABEDORIA DA ILUMINAÇÃO DE SUHRAWARDİ}

VERSÃO CORRIGIDA

O EXEMPLAR ORIGINAL DA PRESENTE DISSERTAÇÃO ESTÁ DISPONÍVEL NO CPH.

Dissertação apresentada como requisito parcial para a obtenção do título de Mestre em Letras (Estudos Judaicos e Árabes), na Área de Concentração em Estudos Árabes, ao Departamento de Letras Orientais da Faculdade de Filosofia, Letras e Ciências Humanas da Universidade de São Paulo, sob orientação do Prof. Dr. Miguel Attie Filho.

SÃO PAULO

2013 
Prof. Dr. Miguel Attie Filho (USP), orientador.

$\operatorname{Prof}^{\mathrm{a}} \mathrm{Dr}^{\mathrm{a}}$ Safa Alferd Abou Chahla Jubran (USP), examinadora.

Prof. Dr. Carlos Arthur Ribeiro do Nascimento (PUC-SP), examinador. 


\section{RESUMO}

Suhrawardī (m. 586 H./1191 d.C.) operou uma virada no pensamento filosófico corrente entre os árabes ao desenvolver um modelo filosófico baseado em uma hierarquia descendente de luzes que constituem tudo aquilo que existe. Para estabelecer esse modelo metafísico, Suhrawardī desconstrói a teoria do conhecimento de base aristotélica, comum entre os filósofos de seu tempo, propondo o "conhecimento presencial" ('ilm hudūirī). Para tanto, Suhrawardī criticou principalmente o conceito peripatético de definição, demonstrando sua insuficiência como modo de se conhecer algo, uma vez que o ato de classificar, sem nenhum fundamento na realidade, delimita a mesma realidade. Com efeito, Suhrawardī, em sua principal obra, Livro da Sabedoria da Iluminação, procurou estabelecer as linhas gerais de seu sistema filosófico, a saber: a filosofia iluminacionista. Essa obra se divide em oito tratados, sendo que os três primeiros formam um conjunto que trata da desconstrução da lógica e epistemologia peripatéticas. Entre outras coisas, Suhrawardī estabelece a prioridade do existente sobre a existência assim como afirma que tanto a existência como a contingência - e todas as categorias aristotélicas - não passam de construtos intelectuais $\left(i^{c}\right.$ tibāa $\left.\bar{a} \bar{t}{ }^{c} a q l \bar{l} y a\right)$, sem nenhuma realidade concreta fora do intelecto. $\mathrm{O}$ erro dos falāsifa seguidores do peripatetismo foi ter construído toda a sua metafísica sobre entidades lógicas sem realidade concreta. Nesse sentido, Suhrawardī procurou estabelecer uma nova epistemologia, que não está apoiada apenas na dedução, na existência ou nas categorias, optando pela recusa da teoria do conhecimento aristotélica. $\mathrm{O}$ verdadeiro conhecimento não é dedutivo e não pode advir da definição. É necessário abarcá-lo de uma só vez, com a experiência direta, intuição imediata (iluminação). Com o desenvolvimento de uma filosofia baseada na experiência direta, essas ideias, de base platônica, tomam conta do debate filosófico e se tornam a condição para o conhecimento.

Palavras-chave: filosofia árabe, iluminacionismo, lógica, peripatetismo, Suhrawardī. 


\section{RESUMÉ}

Suhrawardī (m. 586 H/ 1191 d.C.) a accomplit un tournant dans la pensée philosophique en cours chez les arabes, développant un modèle métaphysique fondé sur une hiérarchie descendante de lumières, qui constituent tout ce qui existe. Pour établir ce modèle métaphysique, Suhrawardī a desconstruit la théorie de la connaissance fondée sur celle de fondement aristotélique, commune entre les philosophes de son temps, en proposant la « connaissance présencielle » ( ${ }^{c} i l m$ huudūru $)$. Pour l'accomplir, Suhrawardī a critiqué surtout le concept péripatétique de définition, démontrant son insuffisance en tant que mode de connaître quelque chose, étant donné que l'acte de classer, sans aucun fondement dans la réalité, délimite cette réalité en question. En effet, Suhrawardī, dans son principal ouvrage, le Livre de la sagesse de l'illumination, a cherché à établir les lignes générales de son système philosophique, c'est-à-dire la philosophie illuminacioniste. Cette oeuvre se divise en huit traités, dont les trois premiers forment un ensemble qui étudie la desconstruction de la logique et de l'épistémologie péripatétiques. Suhrawardī établit, entre autres sujets, la priorité de l'existant par rapport à l'existence, de même qu'il soutient que non seulement l'existence, mais aussi la contingence - et toutes les catégories aritotéliciennes - ne sont que des constructions intellectuelles ( $i^{c} t i b \bar{a} r a \bar{t}{ }^{c} a q l \bar{l} y a$ ), sans aucune réalité concrète en dehors de l'intellect. La faute des falāsifa qui suivent le péripatétisme a été celui d'avoir bâti toute leur métaphysique sur des entités logiques, sans réalité concrète. Dans ce sens, Suhrawardī a cherché à établir une nouvelle épistémologie, qui ne s'apuie pas seulement sur la déduction, sur l'existence ou sur les catégories, en choisissant pour refuser la théorie de la connaissance aristotélicienne. La vraie connaissance n'est pas déductive et ne peut pas advenir de la définition. Il faut l'embrasser d'emblée, avec l'expérience directe, avec l'intuition immédiate (l'illumination). Après le développement d'une philosophie fondée sur l'experience directe, ces idées, de fondement platonicien, ont envahi le débat philosophique et sont devenues la condition pour la connaissance.

Mots-clefs : illuminationisme, logique, péripatétisme, philosophie arabe, Suhrawardī. 


\begin{abstract}
Suhrawardī (d. 586 H 1191 d.C.) has done made a turning point in the current philosophical thought among the Arabs, developing a metaphysical model based on a top-down hierarchy of lights, which are all that exists. To establish this metaphysical model, Suhrawardi has broken the theory of knowledge based on the Aristotelian traditon, common basis between the philosophers of his time, by offering "knowledge by the presence" ( ${ }^{c} i l m$ hud $\left.\bar{u} r \bar{\imath}\right)$. To accomplish it, Suhrawardī criticized especially the Peripatetic concept of definition, demonstrating his failure as a mode of knowledge of something, given that Act to classify, without any basis in reality, restricted this same reality. Indeed, Suhrawardī in his main work, the Book of the wisdom of illumination sought to establish the general lines of his philosophical system, that is the philosophy of illumination. This work is divided into eight treaties, of which the first three are investigating the overthrow the deconstruction of the Peripatetic logic and epistemology. Suhrawardi establishes, among other things, the priority of the existing relative existence, though he argues that not only the existence, but also the contingency - and all Aristotelian categories - are only intellectual constructs $\left(i^{c} t i b \bar{a} r \bar{a} t^{c} a q l \bar{l} y a\right)$, without any concret reality outside the intellect. The fault of the falāsifa following the Peripatetics position, was the one to have built their metaphysics on logical entities, without any concrete reality. In this sense, Suhrawardī sought to establish a new epistemology, which does not rely only on the deduction, the existence or categories, choosing to reject the Aristotelian theory of knowledge. The true knowledge is not deductive and can not happen to the definition. It should embrace it to at the outset, with direct experience, with immediate intuition (illumination). With the development of a philosophy based on direct experience, these ideas, in platonic basis, invaded the philosophical debate and became the condition of knowledge.
\end{abstract}

Keywords: Arabic philosophy, illuminationism, logic, peripatetism, Suhraward̄̄. 


\section{AGRADECIMENTOS}

Quero agradecer à Ordem dos Pregadores. De maneira especial, quero agradecer a l'Institut Dominicain d'Études Orientales (IDEO) do Cairo pelas oportunidades que estão abertas e pela fraternidade. Agradeço especialmente aos professores Emilio Platti OP, Jean-Jacques Perennès OP e Claude Gilliot OP. Quero agradecer também aos professores dominicanos e, principalmente, "ex"-dominicanos pela sabedoria transmitida, entre os quais, merece destaque especial o grande savant Carlos Arthur, sempre solícito e bem humorado.

Quero agradecer ao Departamento de Letras Orientais da Universidade de São Paulo por sempre ter me aberto as portas. Agradeço aos professores, em especial, ao Prof. Mamede e, particularmente, à Prof ${ }^{\mathrm{a}}$ Safa pelos inúmeros auxílios. Agradeço também aos alunos, principalmente os colegas dos Estudos Árabes. Agradeço de maneira especial a Ana e a Nathalia por muitas coisas, entre as quais, a amizade.

Tenho muito que agradecer ao Prof. Miguel, a meu ver, a principal autoridade em estudos de filosofia árabe no Brasil. Sem a sua orientação, muito provavelmente, o autor da presente dissertação não teria ido muito longe... No entanto, não é por isso que quero agradecer. Agradeço pelo seu desejo de multiplicar conhecimento e de construir novas amizades.

Agradeço à Prof ${ }^{\mathrm{a}}$ Catarina Belo, da American University in Cairo, pelas indicações bibliográficas.

Quero agradecer às diferentes gerações de orientalistas das mais diversas nacionalidades e às constantes brigas que houve entre esses estudiosos. Esses eruditos e suas interpretações conflitivas facilitaram - e muito - o desenvolvimento desse trabalho. Assim como também o dificultaram - e muito.

Sou grato aos meus familiares por praticamente tudo. Quero expressar todo reconhecimento, estima e profundo afeto a minha mãe Eunice, ao meu pai Pedro, ao meu avô Virgílio e a minha irmã Magda.

Quero manifestar meu carinho e gratidão a Suyanne, sem a qual a presente dissertação não teria nem sequer sido iniciada ou imaginada.

Enfim, reconheço que o teor especulativo do presente trabalho, tanto em seus acertos e vôos como em seus limites e quedas, se deve, em grande parte, a AmBev. Agradeço aos amigos de copo. 
A Suyanne Gurgel Souza. 


\section{SUMÁRIO}

Tabela de transliteração de letras árabes 1

Introdução

\section{CAPÍTULO I}

\section{SUHRAWARDĪ: VIDA E OBRA}

1. Alguns dados biográficos 14

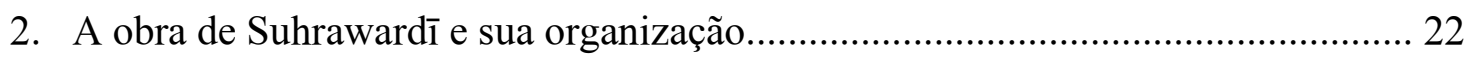

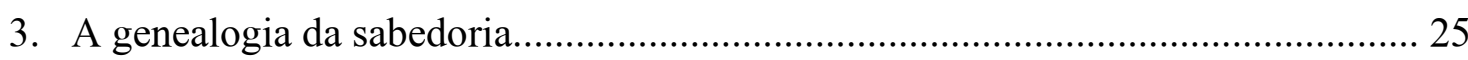

4. Apresentação do Livro da sabedoria da iluminação: o conhecimento pelas luzes.

\section{CAPÍTULO II}

\section{A LÓGICA DE SUHRAWARDĪ E A DESCONSTRUÇÃO DA LÓGICA} ARISTOTÉLICA

1. O Livro da sabedoria da iluminação: estrutura, método e conteúdo. 36

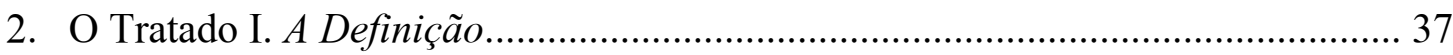

3. Tratado II: Sobre as provas e os seus princípios................................................... 43

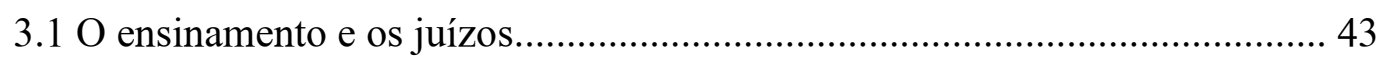

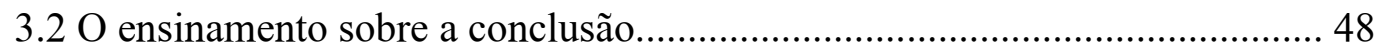

3.3 Sobre as provas entre as ciências e sobre as induções (completas e

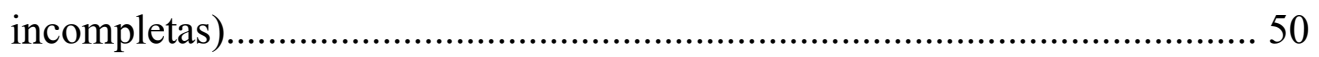

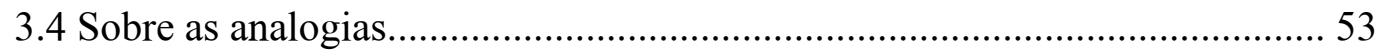

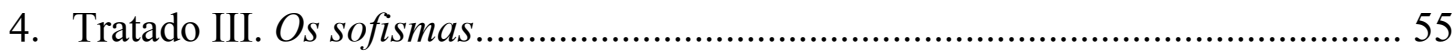

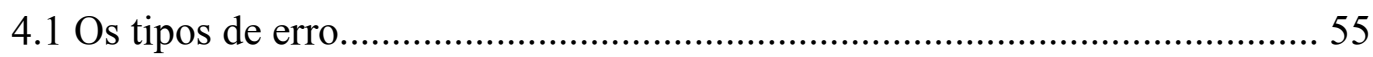

4.2 Referências ao ensinamento dos seguidores dos peripatéticos..................... 59

4.2.1 A descrição do significado dos termos

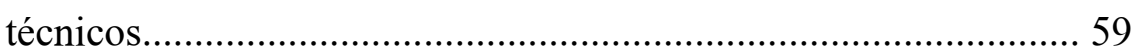

4.2.2 A existência e o existente ........................................................... 61

4.2.3 A identificação por meio da cópula.............................................. 63

4.2.4 A natureza puramente lógica de todos os construtos

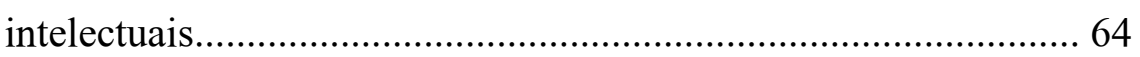


4.2.5 As contradições na doutrina de forma e

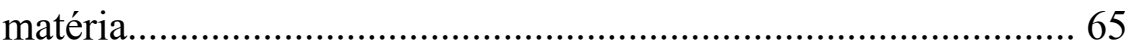

4.2.6 Refutação do átomo particular e do vácuo.................................. 67

4.2.7 Convergências e divergências com a escola peripatética sobre as doutrinas da imortalidade da alma e da unicidade do

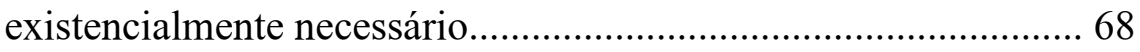

4.2.8 Defesa de Suhrawardī da realidade dos símiles platônicos

4.2.9 A doutrina iluminacionista da pluralidade de causas para uma coisa simples 72

4.2.10 Certos juízos correspondentes às percepções e que serão úteis na ciência das luzes 72

\section{CAPÍTULO III}

\section{A CONSTRUÇÃO DA CIÊNCIA DAS LUZES}

1. Primeiro tratado: Sobre a Luz e sua essência. Sobre a Luz das Luzes e o que flui dela por primeiro, em nove seções e regras - apresentação da metafísica de Suhrawardī..... 76

2. Segundo tratado: Sobre a ordem da existência, em catorze sessões - a cosmologia de Suhrawardī. 82

3. Terceiro tratado: Sobre o modo da atividade da luz das luzes e luzes dominantes e complemento da exposição sobre os movimentos celestes, em quatro seções - a física de Suhrawardī.

4. Quarto tratado: sobre as divisões dos limitrofes, sobre suas qualidades, sua composição e algumas de suas propriedades, em oito seções - a continuação da física de Suhrawardī e apresentação de sua antropologia: fundamentação da psicologia de Suhrawardī.... 94

5. Quinto tratado: Sobre o retorno, as profecias e os sonhos, em nove seções - o retorno ao uno. A escatologia e a profetologia de Suhrawardī 99

Conclusão 107

Bibliografia 134 
TABELA DE TRANSLITERAÇÃo DE LETRAS ÁRABES

\begin{tabular}{|c|c|}
\hline l $\quad \bar{a}$ & b \\
\hline ب b & $\varepsilon^{c}$ \\
\hline$ت \mathrm{t}$ & $\dot{\varepsilon} \quad \dot{\mathrm{g}}$ \\
\hline$ث \underline{\mathrm{t}}$ & ف f \\
\hline ج j & ق q \\
\hline$\tau \mathrm{h}$ & s $\mathrm{k}$ \\
\hline$\dot{\tau} \mathrm{h}$ & 1 \\
\hline$د d$ & $\rho \mathrm{m}$ \\
\hline$\dot{d}$ & n \\
\hline$J r$ & - $\mathrm{h}$ \\
\hline j z & $\rho \quad \overline{\mathrm{u}} / \mathrm{w}$ \\
\hline س S & ى $\overline{1} / y$ \\
\hline ك̆ ش & $=6$ \\
\hline ș ص & \\
\hline به ض & $\left(\begin{array}{ll}l & a\end{array}\right)$ \\
\hline b ț & $\left(\begin{array}{ll}s^{\prime} & \ddot{a}\end{array}\right)$ \\
\hline
\end{tabular}




\title{
INTRODUÇÃO
}

\section{Suhrawardī, a falsafa e a herança de Ibn Sinā}

\author{
Suhrawardī pertence à falsafal desenvolvida na parte oriental do mundo \\ muçulmano cujo mestre principal foi Abū Nașr Muḥammad Ibn Muhammad al-Fārābīin
}

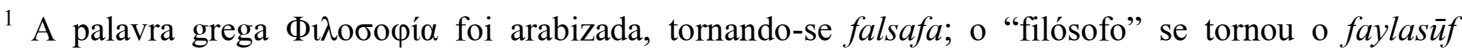
(plural: falāsifa). A tradução de falsafa é objeto de debate entre os orientalistas. Em geral, costuma-se traduzir por "filosofia islâmica". Não obstante, boa parte dos que optaram por essa tradução concordam no seu caráter extremamente problemático (por exemplo, FAKRY, M. Histoire de la philosophie islamique. [traduction du anglais par Marwan NASR]. Paris: Cerf, 1986 - a nosso ver, o mais completo manual de história da falsafa em língua ocidental). Henry Corbin, em sua Histoire de la philosophie islamique (Paris: Enciclopédie de la Pléiade, 1974), na Introdução, procura mostrar não ser exato traduzir falsafa como filosofia árabe, pois seria impossível definir o que é árabe e a falsafa é, para Corbin, conceitualmente islâmica. No entanto, chamar a falsafa de "filosofia islâmica", não nos parece ser correto. Com efeito, a falsafa não é especulativamente islâmica - boa parte dos falāsifa eram historicamente muçulmanos, mas não necessariamente, sob o ponto de vista conceitual e doxológico, muçulmanos -; os filósofos cristãos de Bagdá são verdadeiros falāsifa, assim como os judeus de alAndalus no sécs. V-VI H./XI-XII d.C. e os do Egito no séc. XIII d.C. Uma opção, a nosso ver válida, é a adotada por A. Badawi (Histoire de la philosophie en Islam. Paris: J. Vrin, 1972), seguindo Carra de Vaux (Les penseurs de l'Islam. Paris: Félix Alcan, 1900): “filosofia no islã", entendendo por islã, não o credo, mas a civilização e o império. Também houve aqueles que forjaram neologismos destinados a mostrar que quando se fala em "fillosofia islâmica", "islâmica" quer atentar unicamente à civilização. Assim, por exemplo, Lawrence Berman ("The Ethical Views of Maimonides within the Context of the Islamicate Civilization" in J. Kraemer (ed.), Perspectives on Maimonides. Philosophical and Historical Studies, Oxford, Oxford University Press, 1991, pp. 13-32) criou, em inglês, o termo "islamicate". Outra saída é traduzir simplesmente como "filosofia árabe". Com efeito, se pode objetar a falta de clareza no termo "árabe". O que é "árabe”? ou mais exatamente "quem é árabe?" Etnicamente falando, boa parte dos falāsifa não são árabes - são persas, curdos, siríacos, caldeus, coptas, andalusinos, etc. Não obstante, deve-se reconhecer que os textos de filosofia em questão foram escritos em árabe. Uma solução válida é, a nosso ver, a apresentada por Attie Filho (Falsafa: a filosofia entre os árabes. São Paulo: Palas Athenas, 2002): a de traduzir falsafa como "filosofia entre os árabes". Embora válida e verdadeira, não nos contentamos com ela. Entendendo "árabe" como a língua na qual se produziu a falsafa e não a etnia de cada autor, pode-se falar em "filosofia em árabe". Posições nesse sentido foram assumidas, por exemplo, por A.-M. Goichon (Lexique de la langue philosophique d'Ibn Sinā (Avicenne). Paris, 1938) e Roger Arnaldez (À la croisée des trois monothéismes. Paris : Albin Michel, 1993). "Filosofia em árabe" pode ser uma boa maneira de traduzir falsafa, sendo, ao que nos consta, assim como "filosofia de língua árabe", a mais difundida e melhor aceita atualmente. É verdadeiro que os falāsifa, como dissemos, escreveram em árabe; mas, também é verdade que os filósofos cristãos de Bagdá escreveram em siríaco e houve autores, como Ibn Sīnā, al-Ḡāzālī, al-Suhrawardī e Mulla Șadrā, entre outros, que escreveram em persa, assim como autores judeus que escreveram em hebraico. Como bem observa Rémi Brague (Au moyen du Moyen Age - Philosophies médiévales em chrétienté, judaïsme et islam. Chatou : Éditions de La Transparence, 2006), a ninguém ocorreu a ideia de falar em "filosofia de língua grega", "filosofia em grego", "filosofia de língua latina, "filosofia em latim", "filosofia de língua alemã" ou "filosofia em alemão". Prefere-se, simplesmente, falar de "filosofia grega", "filosofia latina" e "filosofia alemã", mesmo se a língua não coincide com a origem étnica, e ainda menos com a noção moderna de nacionalidade. O grego também foi empregado por macedônios como Aristóteles e, mesmo por fenícios como Zenão, o estoico, ou Porfírio ou pelo egípcio Plotino. Da mesma maneira, ao que nos consta, nunca se gerou polêmica saber se o africano Agostinho de Hipona, ou o anglo Roger Bacon ou o germânico Alberto Magno poderiam ser considerados latinos. Por fim, houve uma filosofia alemã bem antes de 1871, que até mesmo conheceu, na nossa leitura, um apogeu em um momento em que não se vislumbrava uma unidade e uma cidadania alemã. Assim, seguindo Brague, adotaremos simplesmente o nome "filosofia árabe", acreditando ser mais exato e direto. Da
\end{abstract}


(m. 339 H./ 950 d.D.). A obra deste último é considerável; seu comentário às obras de Aristóteles deixaram marcas na história da filosofia. Seu sistema de mundo repousa sobre a ideia de um fluxo (fayd) que, a partir do primeiro princípio, faz aparecer uma sucessão de intelectos que, por sua própria natureza, põe em movimento o primeiro céu das estrelas fixas, depois as esferas dos planetas até chegar à esfera da Lua. $\mathrm{O}$ intelecto lunar não engendra outras esferas, mas é a inteligência ativa doadora das formas (wāhib al-ṣuwar) constitutiva dos seres do mundo sublunar, sendo também o princípio de conhecimento intelectivo para as almas humanas. Estabelece-se, assim, uma síntese entre a cosmologia ptolomaica, a física aristotélica e a filosofia neoplatônica. Fārābī inspirou decisivamente o pensamento de Ibn Sīnā, sendo este o mais celebrado filósofo árabe que viveu a oriente de Bagdá ${ }^{3}$.

mesma maneira, não teremos nenhum pudor em chamar Suhrawardī e qualquer faylasūf de "árabe". Acreditamos que qualquer solução diferente complicaria desnecessariamente a história da filosofia. Seguindo Georges Anawati \& Louis Gardet (Introduction à la théologie musulmane - essai de théologie comparé. Paris: Vrin, 1948), indicamos que, caso se queira procurar uma filosofia conceitual e especulativamente muçulmana não devemos procurá-la na falsafa, mas no ${ }^{c} i l m$ al-kalām, a teologia muçulmana - embora haja pesquisadores da maior competência, como A.F. Mehren, Max Horten, Léon Gauthier e Asín Palacios, que veem nos falāsifa, a partir de diferentes (e até mesmo contrastantes) motivos, segundo a concepção de cada um de islã e dos valores da fé islâmica, os verdadeiros apologetas do islã e considerando, assim, a falsafa uma "filosofia muçulmana", no sentido estrito do termo. (Anawati \& Gardet, op. cit., p. 268, nota 7; cf. tb. pp. 320-324).

${ }^{2}$ Muitos nomes próprios em árabe são antecedidos pelo prefixo $a l$, o único artigo definido dessa língua. Nas transcrições de sobrenomes árabes, formados de adjetivos pátrios ou gentílicos, iniciados por esse artigo, muitos orientalistas optam em mantê-lo e por se tratar de parte do nome próprio, acabam por optar em grafar a letra "a" de $a l$ em maiúscula como em "Al-Fārāb $\overrightarrow{1}$ ". Outros entendem se tratar apenas de um prefixo, preferindo manter a letra "a" em minúscula, como em: "al-Fārābī". Há ainda aqueles que preferem omitir o sufixo $a l$, como em: "Fārābī". Entre os que optam por transliterar o sobrenome com o artigo $a l$, não há acordo sobre se se deve privilegiar o prefixo $a l$ tal qual é pronunciado ou se tal qual ele é escrito. A divergência surge pelo fato de que em alguns casos, o "l" de al é assimilado pelo som seguinte que se dobra, assim se poderia, então, ter ar-Rāzī ou Ar-Rāzī; as-Suhrawardī ou AsSuhrawardī; ad-Dīn ou Ad-Dīn. Há também os que optam simplesmente por transliterar o sobrenome na maneira que é registrado na língua árabe, com a permanência do 'l'; assim, se teria: al-Rāzī ou Al-Rāzī; al-Suhrawardī ou Al-Suhrawardī; al-Dīn ou Al-Dīn. Por fim, há aqueles que simplesmente optam em omitir o prefixo al. Como não há uma convenção padronizada, optamos neste trabalho por: quando o nome próprio aparece pela primeira vez, será registrado com artigo, iniciado com 'a' minúsculo, (salvo nos lugares em que a língua portuguesa exigir que se inicie com letra maiúscula). No entanto, quando esse nome se repetir, nós simplesmente omitiremos a partícula $a l$. Em suma, escreveremos al-Fārābī, alĠāzālī, al-Suhrawardī e al-Rāzī na primeira vez que esses nomes próprios aparecerem no texto; nas demais vezes grafaremos apenas Fārābīi, Ġāzālī̄, Rāzị, Suhrawardī. No caso dos nomes composto com 'ibn' (filho de) e 'abū' (pai de), nossa opção é por registrar a primeira letra em máscula, como em 'Ibn Sīnā" e não em minúsculo como em "ibn Sīnā". Em ambas as escolhas, seguimos o que nos pareceu mais corrente.

${ }^{3}$ Houve outros nomes importantes entre os filósofos árabes nascidos nas terras orientais do islã. Um deles, por exemplo, foi Ibn Miskawayh (320 H./ 932 d.C. - 421 H./ 1030 d.C.), cujo saber abraça a história, a ética e a teoria do conhecimento. Nesse ponto, seu trabalho é comparável ao de Fārābī e de Ibn Sīnā. 
Muitas vezes os livros e manuais de história da filosofia, de maneira demasiadamente rápida, reduzem o pensamento filosófico árabe aos três grandes personagens Fārābī (Alfarabi), Ibn Sīnā (Avicena) e Ibn Rušd (Averróis) - talvez pela importância desses filósofos no século XIII d.C. entre os pensadores latinos e na constituição da filosofia "ocidental". Houve uma lista extensa de amantes e cultivadores da antiga sabedoria greco-helenística entre os árabes; gerações e gerações de filósofos debateram os mais diferentes problemas filosóficos. O centro de gravidade desses movimentos filosóficos foi Bagdá. Foi, entretanto, longe da capital abássida e por meio de um médico que nunca pisara no Iraque que a filosofia árabe atingiu o seu mais alto nível de especulação teórica e de sistematização. Não que ele haja sido o "único" ou "o melhor", mas foi aquele que mais se sobressaiu. Trata-se de Ibn Sīnā.

É comum, nos livros e manuais de filosofia medieval - isso quando falam da filosofia árabe, não poucas vezes, solenemente ignorada - se afirmar que Abū Ḥāmid Muḥammad Ibn Muḥammad al-Ġāzālī (450 H./ 1058 d.C. - 505 H./ 1111 d.C.) dera o golpe fatal na filosofia nas terras orientais da civilização islâmica. O pensamento filosófico haveria sobrevivido apenas - e por pouco tempo - nas terras ocidentais, mais exatamente em al-Andalus, até o seu ocaso, em fins do século VI H./XII d.C. Dessa maneira, Ibn Rušd (m. 595 H./ 1198 d.C.) seria o último filósofo árabe. Esquece-se que, justamente na parte mais oriental das terras do islã, mais precisamente em terras de língua e cultura persa, a filosofia greco-árabe se manteve viva até os dias atuais. Com efeito, se se entende a filosofia árabe como a filosofia que se fazia até então, pode-se dizer que a filosofia oriental aí encontrada não seria, efetivamente, a mesma coisa que filosofia árabe anterior. Mas essa nova maneira de fazer filosofia, antes de negar as origens da filosofia árabe, as coloca dentro de um quadro maior, o da hikma (sabedoria). Não se trata de ruptura, pura e simples, mas de continuidade.

Tal atitude, porém, não é exclusiva dessa filosofia surgida a oriente, mas é partilhada por outros filósofos árabes anteriores a al-Suhrawardī. Enquanto no extremo ocidente da civilização islâmica Ibn Rušd desenvolvia seu pensamento, a oriente, Suhrawardī estabelecia seu método filosófico. Ambos, em língua árabe, levam, por caminhos diferentes - e muitas vezes opostos -, ao pleno desenvolvimento e consequências últimas a herança dos demais filósofos árabes, seus antecessores. Ambos romperam barreiras e estabeleceram novos paradigmas. Enquanto a figura de 
Ibn Rušd conseguiu alçar voos maiores fora da civilização islâmica, precisamente no Ocidente latino-germânico, Suhrawardī conseguiu que suas obras (as de filosofia e ciência, como era costume, em árabe) fossem integradas por uma parcela considerável do islã. Desse modo, é correto se afirmar que ambos, cada qual do seu jeito, deram novos rumos à filosofia árabe, ainda que, de maneira diferente, isso já fosse presente em outros filósofos árabes. Suhrawardī, assim, conseguiu deixar descendência de maneira visível no interior do islã.

Ibn Rušd e Suhrawardī se destacam como os principais pensadores na filosofia árabe que surgiram após a morte de Ibn Sīnā - mas não os únicos. Pode-se acrescentar uma enorme lista com pensadores geniais como o lógico Abū al-Barakāt al-Bag̉dādī e o teólogo Faḩr al-Dīn al-Rāzī, sem contar o multifacetário Ġazālī ou os

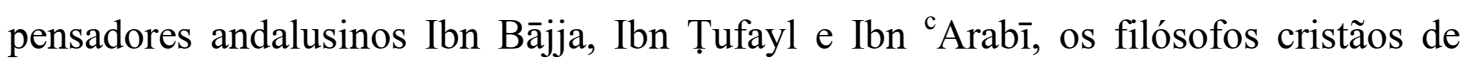
Bagdá, os filósofos e teólogos filosofantes árabo-judeus em todo o mundo árabe, entre muitos outros. Foram herdeiros da tradição de Ibn Sīnā, seus discípulos e sucessores, seus críticos e adversários - a exceção do círculo filosófico árabo-cristão, sobretudo o de Bagdá, formado principalmente por cristãos de origem siríaca, no qual a influência de Ibn Sīnā pouco impactou. Os dois séculos que se seguiram à morte de Ibn Sīnā (429 H./ 1037 d.C.) foram um período de intenso debate. Essa série de debates se inclui em outro debate maior sobre a identidade islâmica e a verdadeira hermenêutica do islã. Foi em particular o século VI H./ XII d.C. o período em que esses debates e a crise interna do pensamento árabe e muçulmano chegou ao seu limiar.

A tradição aviceniana - além do próprio Ibn Sīnā - inclui seus discípulos contemporâneos e a primeira geração de discípulos formada, na maior parte, por comentadores, tradutores e defensores do legado de Ibn Sīnā. Considerável número de seus textos sobreviveu, alguns sob a forma de comentários ou de correspondência, isto é, respostas de Ibn Sīnā para as consultas de seus discípulos. Entre estes, se pode incluir Abū Manșūr Ibn Zaylah (m. 439 H./ 1048 d.C.), que também escreveu comentários ao Hayy Ibn Yaqzāan ${ }^{4}$. Bahmayār Ibn Marzbān, apresenta questões que são

\footnotetext{
${ }^{4}$ MEHREN, Traités mystiques de Aboû Alî al-Hosain b. Abdallâh b. Sinnâ ou Avicenne, texte arabe accompagne de l'explication en français par M.A.F. MEHREN. Leyden: E. J. Brill, 1888-99 [reimpresso (4 fascículo em 1 único volume) em Leiden: A.P.A, 1979], fasc. I.
} 
respondidas por Ibn Sīnā em Discussões ${ }^{5}$. Abū c Ubayd Jūsjānī (m. depois de 429 H./ 1037 d.C.), discípulo, amigo e biógrafo de Ibn Sīnā, foi o único discípulo mencionado por Ibn Sīnā em sua autobiografia ${ }^{6}$. A Abū ${ }^{\mathrm{c}}$ Abd Allāh al- Ma ${ }^{\mathrm{c}} \operatorname{su} \bar{m} \mathbf{i}$ (m. 429 ou 450 H./ 1038 ou 1058 d.C.) foi escrito por Ibn Sīnā o seu Tratado sobre o amor. Há também uma correspondência entre Bīrūnī e Ibn Sīnā que contém a defesa de Ibn Sīnā por Ma ${ }^{c}$ șūmī. Outro importante divulgador da filosofia de Ibn Sīnā foi Kiā Bahmanyār Ibn al-Marzbān (Aḍarbājān̄̄) (m. 358 H./ 1066 d.C.), autor do livro Sobre as opiniões dos mestres peripatéticos relativamente a questões da alma e de suas faculdades ${ }^{7}$ e seu discípulo Faḍl Ibn Muhammad Abū al- ${ }^{\mathrm{C}}$ Abbās al-Lawkarī (m. 517 H./ 1123 d.C.), responsável pela disseminação do pensamento de Ibn Sīnā em Ḩurāsān e autor de um trabalho popular cujo objetivo era apresentar Fārābī e Ibn Sīnā, chamado Explanação da realidade pertencente à verdade, contendo partes reservadas à lógica, física e ciência divina ${ }^{8}$.

Os primeiros discípulos de Ibn Sīnā mantiveram vivo o peripatetismo aviceniano. Entretanto, logo se desenvolveu uma tradição crítica a esse peripatetismo, desenvolvida, principalmente, por nomes importantes na história da teologia muçulmana - Ġāzālī (505 H./ 1111 d.C.), Tāj al-Dīn Abū al-Fat Muḥammad Ibn ${ }^{\text {c} A b d ~}$ al-Karīm al-Šahrastānī (m. 548 H./ 1153 d.C.) e Faḩr al-Dīn al-Rāzī (m. 606 H./ 1209 d.C.), contemporâneo de Suhrawardī. Esses teólogos muçulmanos se mostraram, cada qual à sua maneira, extremamente críticos ao peripatetismo árabe, de um modo geral, e a Ibn Sīnā, em particular, pois, para eles, a filosofia peripatético-aviceniana poderia, por assim dizer, minar doutrinas fundamentais no islã - embora a teologia desses mestres fosse, em graus diferentes, muito influenciada tanto pelo peripatetismo como por Ibn Sīnā. Graças, em grande parte, a esses teólogos, o peripatetismo de Ibn Sīnā passou a se encontrar no centro dos debates, e assim permaneceu no tempo de Suhrawardī. Um dos mestres de Suhrawardī em Iṣfahān , 'Umar Ibn Sahlān al-Sāwī, por exemplo, glosou al-Najāt de Ibn Sīnā em resposta ao criticismo de Šahrastānī. Em resposta às críticas ao peripatetismo de Ibn Sīnā lançadas por Faḩr al-Dīn al-Rāzī em

\footnotetext{
5 MICHOT, Jean. «La réponse d'Avicenne à Bahmanyâr et al-Kirmâni. Présentation, traduction critique et lexique arabe-français de la Mubâhatha III »Mu. 110, 1997 ; pp. 143-221 ; p.147.

${ }^{6}$ GUTAS, Dimitri. Avicenna and the Aristotelian tradition - Introduction to reading Avicenna's philosophical works. Leiden: E. J. Brill, 1988, 342p., pp. 22-30.

${ }^{7}$ Ibid., p. 143 , v. tb. nota 4.

${ }^{8}$ Ibid., p. 143.
} 
seu Comentário às Observações de Ibn Sīnā, o filósofo e enciclopedista Nașīr al-Dīn al-Ṭūsī (m. 672 H./ 1274 d.C.), escreveu um comentário às mesmas Observações de Ibn Sīnā, no qual se revela um grande defensor do sistema aviceniano.

Ġāzālī demonstra grande conhecimento do pensamento dos diferentes filósofos árabes e, sobretudo de Ibn Sīnā no Propósito dos filósofos, primeira parte de seu famoso Derrocada dos filósofos. Essa obra pretende atacar aquilo que, aos olhos de Ġāzālī, na filosofia contradiz os fundamentos do islã - visando, fundamentalmente, Fārābī e Ibn Sīnā. Ironicamente, os ataques de Ġāzālī ajudaram a disseminar a filosofia de Ibn Sīnā para além da Pérsia e da Mesopotâmia. Ibn Sīnā ganhou, dessa maneira, interlocutores no Ocidente, precisamente em Andalus, com autores como Ibn Bājja (m. 533 H./ 1139 d.C.) Ibn Țufayl (m. 581 H./ 1185 d.C.) e Ibn Rušd ${ }^{9}$ O ataque de Ġazālī à filosofia, com efeito, acabou por servir de munição para os que os adversários da especulação filosófica em Andalus, preparando o seu fim entre os muçulmanos andalusinos, após a morte de Ibn Rušd. Uma leitura atenta da obra de Ġazālī revela grande influência dos filósofos árabes - e do próprio Ibn Sīnā - em seu pensamento. Esse Ġazālī "fillosofante" preparou, em certo sentido, a propagação da filosofia iluminacionista de Suhrawardī e a "gnose" filosófica ( ${ }^{c} i r f a \bar{n}$ ) de Ibn ${ }^{\text {c }} \mathrm{Arab}^{10}$ (m. 638 H./1240 d.C.).

\footnotetext{
${ }^{9}$ O próprio Ibn Rušd deve ser incluído entre os críticos ao peripatetismo de Ibn Sīnā. Sua crítica, entretanto, é de natureza diferente. Não se trata de libertar a filosofia árabe - e seu principal filósofo Ibn Siña - do peripatetismo, mas de purificar o peripatetismo aviceniano, retornando ao Aristóteles puro, algo que não haveria sido compreendido por Ibn Sīnā, demasiadamente "platonizado".

${ }^{10} \mathrm{O}$ lugar de $\mathrm{Ibn}{ }^{\mathrm{c}}$ Arabī no pensamento árabe é difícil de se estabelecer. Sua fonte de inspiração se insere em disputas teológicas e é profundamente marcada pelo kalām, embora assuma, em pontos importantes, posições críticas em relação à teologia muçulmana. Ibn ${ }^{\mathrm{C}}$ Arabī se apresenta como herdeiro de uma tradição profética, sem nenhum intermediário, a não ser a recepção direta de verdades superiores; entretanto, Ibn ${ }^{\mathrm{c}}$ Arabī está bem consciente de que muitas coisas por ele expostas são parecidas ou mesmo idênticas às questões debatidas pelos filósofos da Antiguidade ou pelos seus continuadores árabes, os faläsifa. Chega a afirmar o acordo de sua doutrina com a de certos filósofos árabes. Percebe-se em sua obra considerável influência de diversos filósofos árabes, sobretudo de Ibn Sīnā e de Ġāzālī. Da mesma maneira, Ibn ${ }^{\mathrm{c} A r a b i ̄ a p r e s e n t a ~ p o s t u r a ~ c r i ́ t i c a ~ e m ~ r e l a c ̧ a ̃ o ~ a ~ I b n ~ S i ̄ n a ̄ ~ e ~ a o ~}$ peripatetismo, o que lhe aproxima de Ġāzālì e, principalmente, de Bag̉dādī, Suhrawardī e Faḩr al-Dīn al-Rāzì. Um exemplo disso é o uso das categorias aristotélicas (al-maqūlāt), na qual assinala a correspondência que poderiam ter com a sua cosmologia e a sua escatologia, assim como o limite das próprias categorias no que se refere ao seu fundamento lógico. Assim, a lógica aristotélica dificilmente poderia se localziar em um método em que a aquisição do conhecimento põe o raciocínio e a especulação intelectual entre parênteses. No entanto, a exposição discursiva do saber recebido pelo desvelamento (kašf) e pela iluminação só pode se passar por meio de uma terminologia filosófica. A referência às categorias, por exemplo, oferece um caso particularmente significativo da maneira em que o "espiritual" se apropria de conceitos destinados, provavelmente, em sua origem, a outra utilização.
} 
O grande polemista Šahrastānī ${ }^{-11}$ também criticou a falsafa por motivos de ordem teológica, em particular, Ibn Sīnā e sua teoria da emanação e a sua escatologia no que se refere ao destino da alma após a morte. Entrementes, seu Livro das religiões e das seitas, contém inteiras seções em que procura mostrar o quanto o sistema de Ibn Sīnā é contrário aos princípios islâmicos. Šahrastānī escreveu considerável número de outros trabalhos em que ataca especificamente as doutrinas dos filósofos.

Finalmente, Rāzī, aluno de filosofia, medicina, matemática e jurisprudência com Majd al-Dīn al-J̄̄līe, também mestre de Suhrawardī, em Marāgàah, foi um importante comentador do Alcorão. Nasceu em Rayy, próximo de Teerã, em 543 H./ 1149 d.C. e morreu em 606 H./1209 d.C. Trata-se de um dos espíritos mais largos e mais completos da história do islã. Teólogo $a \breve{S}^{\complement}$ arita, foi discípulo de Ġāzālī; ele soube aliar seu sistema teológico com os seus conhecimentos profundos nas ciências de seu tempo. Autor de um dos mais completos comentários do Alcorão, Mafätih al-ġayb ( $A$ chave do invisivel), em que examina todos os aspectos possíveis de cada versículo: filológico, teológico, jurídico, histórico, geográfico, filosófico e, em muitas perícopes, deixa um espaço importante ao ponto de vista dos místicos. Em sua obra revela grande erudição filosófica, procurando estabelecer uma síntese entre as diferentes escolas do ${ }^{c} i l m$ al-kalām e as da falsafa. Em filosofia, se apropriou do sistema aviceniano e procurou elaborar um sistema que harmonizasse Ibn Sīnā, Ġāzālī e Bag̉dādī. Nesse sentido, se revelou também, um duro crítico de Ibn Sīnā e, principalmente, de seu peripatetismo, apontando contribuições originais para a lógica, a filosofia da matemática e a epistemologia. Seu criticismo transparece em seus Comentários às Observações de Ibn Sīnā e em suas obras Quintessência das Observações ${ }^{12}$, Origens da sabedoria e seu polêmico Livro das controvérsias; em suas Coleções está presente

Poder-se-á, então, analisando certas passagens em que Ibn ${ }^{c} A r a b \overline{1}$ faz alusão às categorias, observar o uso do Organon e se interrogar sobre a intenção de Ibn ${ }^{c} A r a b \overline{1}$ ao fazer isso. Não sabendo responder exatamente se $\mathrm{Ibn}^{\mathrm{c}}{ }^{\mathrm{A}} \mathrm{Arab} \overline{\mathrm{l}}$ deve ou não ser incluído entre os filósofos árabes, traduziremos, ainda que possa ser de maneira inapropriada, "irfān como "gnose", na falta de outro termo filosoficamente mais rigoroso. (cf. GRIL, Denis. « Ibn "Arabī et les catégories » in PERLER, Dominik \& RUDOLPH, Ulrich (org) Logic und Theologie : das Organon im arabischen und im lateinischen mittelalter. Leiden: Brill, 2005, pp. 147-165, p. 148).

${ }^{11}$ SHAHRASTANI. Livre des Religions et des Sectes, vol. I (Traduction avec introduction et notes par Daniel GIMARET et Guy MONNOT). Leuven : Peeters/Unesco, 1988, 727 pp. ; et vol. II (Traduction avec introduction et notes par Jean JOLIVET et Guy MONNOT). Leveun : Peeters/Unesco, 1993, 578pp.

${ }^{12}$ KRAUS, Paul. Les “controverses” de Fakroddīn al-Rāzī (Bulletin de l'Institut d'Égypte XIX, 1937), p.187-219. 
uma suma das diferentes doutrinas dos filósofos árabes e dos teólogos muçulmanos, contendo uma refutação da argumentação de Ibn Sīnā sobre a imortalidade da alma ${ }^{13}$. Com efeito, na sua obra mais importante, Investigações Orientais - no qual está presente um Livro da alma -, desenvolve uma crítica ao peripatetismo de uma forma geral, e ao de Ibn Sīnā em particular, apontando os limites da lógica aristotélica e desenvolvendo uma nova epistemologia filosófica, no que é similar ao projeto de Suhrawardī. Trata-se de uma obra considerável - em dois volumes, em um total de 1200 páginas - que compreende três livros. O primeiro é consagrado às "coisas universais" (al-umūr al- $\left.{ }^{c} a m m a\right)$ e ao que se apresenta como suas espécies (anwā $\bar{a}^{c}$, ou seja, a existência (wujūd), a quididade (māhiyya), a unidade (wahda), a multiplicidade (katra), a necessidade (wujūb), a possibilidade (imkān), a eternidade (qidam) e a geração temporal (hudūt ). Rāzī expõe a sua doutrina sobre as categorias e, no que se refere às diferentes categorias, suas ideias sobre o contínuo e o descontínuo, o finito e o infinito no espaço e no tempo passado e futuro, sobre as grandezas matemáticas, sobre a corporeidade, sobre o lugar, a superfície e o ponto, sobre as qualidades sensíveis, sobre a ciência, sobre a aprendizagem que não é reminiscência, sobre o inteligível, sobre a vida afetiva, sobre os corpos celestes e elementares, sobre a ciência da alma, etc. O segundo livro é mais específico e trabalha sobre a física, a cosmologia e a psicologia humana. O terceiro livro é consagrado às questões metafísicas ("as coisas divinas", al-ilāhiyyāt). Rāz̄i parte da ideia do existencialmente necessário (wājib al-wujūd) para abordar as questões tratadas pelo kalâm $^{14}$.

A obra de Ibn Sīnā também produziu outro tipo de crítica, genuinamente filosófica, feita por importantes matemáticos e filósofos como Abū al-Barakāt Ibn Malaka al-Bag̉dādī e Šịāa Yahyā al-Suhrawardī, o nosso autor em questão. Bag̉dādī era um astrônomo, médico, filósofo e rabino judeu, convertido ao islã. No momento de sua conversão verteu seu nome, Natanael, para o árabe, Hibat Allāh (“dom de Deus”). Nascido na região de Mossul, por volta de 464 H./1072 d.C., morreu em Bagdá, depois de 547 H./ 1152 d.C. (alguns precisam em 560 H./1165 d.C., não havendo acordo entre seus biógrafos se ele morreu com oitenta ou se com mais de noventa anos

\footnotetext{
${ }^{13}$ MICHOT, Jean. «L'eschatologie d'Avicenne selon F. D. Rāzī », R.P.L. 87 (1989), pp. 131-153.

${ }^{14}$ ARNALDEZ, Roger. Fakr al-Dîn al-Râzî, commentateur du Coran et Philosophe. Paris: Vrin, 2002, pp.130-131.
} 
solares). Ele critica o sistema aviceniano, e apresenta numerosas modificações em seu Livro do que pode ser estabelecido pela reflexão pessoal, que se calca sobre numerosas apropriações e modificações do Kitāa al-Šifāa' de Ibn Sīnā. Em particular, ele pensa que cada alma humana é uma espécie, ou seja, cada alma humana difere especificamente de todas as demais. Em toda sua obra filosófica, merece destaque o seu interesse em rejeitar a cosmologia ptolomaica e a física aristotélica e seu esforço na elaboração de uma nova cosmologia e de uma nova física. Antes de sua conversão ao islã, escreveu um importante comentário ao livro do Eclesiastes. Escreveu também uma importante obra, Considerações sobre a sabedoria. Este livro consiste em uma crítica à filosofia peripatética de Ibn Sīnā e a reformulação de algumas das suas percepções filosóficas mais importantes ${ }^{15}$. Escreveu também uma obra sobre noética, Solidez das Causas na tradição referente à quididade do intelecto. Nessa obra, o mais impressionante são as similaridades entre a filosofia de Bag̉dādī e Suhrawardī - por exemplo, suas angeologias; a percepção da alma sem a ajuda e o intermédio das imagens; certa unidade dos sentidos internos; a noção de visão ${ }^{16}$. Suhrawardī rejeita certas teses de Bag̉dādī, como, por exemplo, sobre a sabedoria ou sobre a percepção. Toda a questão sobre a relação entre os sistemas desses dois filósofos do século VI H./ XII d.C. deve ser ainda melhor estudada.

\section{Divisão de capítulos da dissertação}

É nesse denso século VI H./ XII d.C. que Suhrawardī e sua filosofia se inserem. Trata-se de um personagem complexo. Oriundo do Curdistão persa, esse sábio transeunte, ao longo das inúmeras viagens, conseguiu reunir grande erudição em filosofia, em particular na lógica, e nas ciências de seu tempo, em particular na matemática. Uma vida curta - diga-se de passagem - na qual conseguiu dar novos rumos à filosofia. Uma morte violenta, quando Suhrawardī contava menos de quarenta anos, fez com que se colocasse um ponto final em sua obra. Não obstante, aquilo que se poderia considerar a essência do seu pensamento já se encontrava elaborado e

\footnotetext{
15 PINÈS, S. «La conception de la conscience de soi chez Avicenne et chez Abu'l-Barakāt alBaghdādī », Archives d'Histoire doctrinalle et littéraire du Moyen-Age 21, 1954, pp. 217-218 - para a seção dedicada a Abū al-Barakāt, cf. Ibid., pp. 217-258.

${ }^{16}$ Ibid., pp. 245-257.
} 
sistematizado no Livro da sabedoria da iluminação (Kitāb hikmat al-išrāq) $)^{17}$. O objetivo do presente trabalho é apresentar o método filosófico de Suhrawardī e as linhas gerais de seu sistema filosófico, tais quais são apresentadas na referida obra. Com efeito, visto os debates constantes nos século VI-VII H./ XII-XIII d.C. entre os filósofos árabes sobre o alcance e os limites da filosofia peripatética, sobretudo no que se refere à lógica e à epistemologia, daremos destaque maior à crítica de Suhrawardī à lógica peripatética e a própria lógica suhrawardiana. Para isso, este trabalho está dividido em três capítulos.

Para apresentar Suhrawardī - ao que nos consta, trata-se do primeiro trabalho acadêmico em língua portuguesa sobre esse filósofo -, iniciaremos o primeiro capítulo com uma breve biografia do autor. Uma vez realizado esse caminho, apresentaremos o caráter e o conteúdo de suas obras, sua organização e as diferentes interpretações que giram em torno dela. Sobre isso, nos últimos vinte anos, diversos historiadores da ciência e da filosofia árabe e islamólogos discutiram o alcance e os limites da verdadeira natureza da contribuição de Suhrawardī à civilização árabo-muçulmana. Essas discussões são alimentadas, em grande parte, pelo caráter multifacetário da obra de Suhrawardī. Seguiremos ao longo do trabalho a hipótese de Hossein Ziai, sustentando que o aspecto preponderante de sua filosofia está relacionado com sua crítica à filosofia peripatética, a lógica, em particular, e como essa crítica à lógica aristotélica serve de fundamento a uma nova metafísica, da qual decorre uma nova ciência. Ziai, a quem nessa empresa acompanha John Walbridge, em sua extensa bibliografia, põe em destaque a amplitude e a unidade dos escritos de Suhrawardī. Sua obra completa, com efeito, tem um centro, em que tanto a crítica à lógica aristotélica como a construção de uma nova metafísica e de um novo método de conhecimento são melhor elaboradas e apresentadas de forma mais sistemática e didática. Trata-se do próprio livro em questão, isto é, do Livro da sabedoria da iluminação. Procuraremos, assim, estabelecer qual o lugar desse livro na obra de Suhrawardī. Encerraremos esse capítulo procurando conhecer qual o fundo tradicional a que se refere Suhrawardī

\footnotetext{
${ }^{17}$ Utilizaremos as duas traduções para línguas ocidentais do Livro da sabedoria da iluminação que temos. Trata-se de uma tradução francesa (Le livre de la sagesse orientale, commentaires de Quoṭboddin SHÎRÂZÎ e Mollâ ȘADRÂ, tradução e notas por Henry Corbin, edição e introdução por Christian Jambet. Paris: Verdier, 1986) e de uma tradução norte-americana (The Philosophy of Illumination, tradução e edição por Jonh Walbridge e Hossein Ziai. Provo: Brigham Young University, 1999).
} 
quando se remete à sabedoria dos antigos, configurando um mapa sapiencial em que se manifestam geograficamente e de modo relevante as tradições egípcia, grega e persa, e, em menor medida, a indiana e a islâmica. Veremos que Suhrawardī, de maneira contundente, afirmou e sustentou que o verdadeiro conhecimento é aquele obtido pelo sábio que possui simultaneamente a sabedoria discursiva e a experiência reflexiva e contemplativa. Por isso, a genealogia que o autor se atribui é significativa, uma vez que cria e confirma uma sabedoria universalmente manifestada e transmitida através de diversos sábios precedentes de diferentes geografias, que expressaram sua verdade por meio da polissemia de símbolos irrefutáveis. Esses diferentes sábios têm, por assim dizer, como pai ou patrono Hermes, e como guia, mestre e chefe Platão.

Como já dissemos, o corpus suhrawardiano é multifacetário; o seu livro não é diferente. Mesmo assim, nele se apresenta, de forma didática e sistematizada, um caminho ascendente que conduz a um clímax, visto que através da ordem e da interrelação de seus textos, Suhrawardī revela aspectos distintos de sua filosofia. São, em linhas gerais, as distintas etapas pelas quais passou o próprio Suhrawardī, que vão de um pensamento estritamente peripatético a uma aceitação, incorporação e combinação cuidadosa de Platão e da sabedoria pré-aristotélica, a "sabedoria dos antigos" conforme se expressa na introdução de seu Livro da sabedoria da iluminação. Como o presente trabalho se encontra centrado nesse texto, tentaremos seguir o percurso tal qual apresentado nesse livro. O Livro da sabedoria da iluminação se divide em duas partes. A primeira parte se divide em três tratados nos quais se apresentam os limites e as contradições presentes na lógica aristotélica e que resulta na desconstrução do método de conhecimento decorrente do aristotelismo. Na segunda parte se constrói uma nova metafísica decorrente da epistemologia apresentada na primeira parte do livro, e da experiência da luz. Dessa metafísica da luz decorrem as mais diversas ciências e saberes (cosmologia, física, antropologia, psicologia, escatologia, etc.). Estabelece-se, assim, a ciência das luzes ( ${ }^{c} i l m$ al-anwār). Essa segunda parte do livro se divide em cinco tratados, por meio dos quais se apresenta cada aspecto do método de conhecimento fundado sobre a metafísica das luzes. Percorremos os oito tratados os três da primeira parte e os cinco da segunda - chamando atenção aos pontos decisivos da filosofia suhrawardiana. 
Os três tratados de lógica serão apresentados com maior atenção e constituirão o capítulo II do presente trabalho. O seu estudo é de fundamental importância para se captar o alcance da lógica de Suhrawardī entre os filósofos árabes do século VI H./XII d.C. No capítulo III apresentaremos os principais pontos da "ciência das luzes", isto é, da metafísica de Suhrawardī, que pretende ser um método seguro para a epistemologia, a cosmologia, a física, a psicologia e a escatologia.

Nosso trabalho tem como hipótese fundamental a "luz" como aquilo que unifica a crítica ao peripatetismo, a recuperação das tradições sapienciais préaristotélicas e a apresentação de uma nova teoria do conhecimento, a do conhecimento presencial e direto. A luz fundamenta um conhecimento intuitivo e que se evidencia ao se auto-apresentar. Em outras palavras, trata-se do processo iluminativo; Suhrawardī nos mostrará não haver nada mais evidente ou manifesto que a luz, aquela que manifesta e evidencia todas as coisas e todo o conhecimento sobre as coisas. 


\section{CAPÍTULO I}

\section{SUHRAWARDĪ: VIDA E OBRA}

\section{Alguns dados biográficos}

Šihāb al-Dīn Abū al-Futūḥ Yahyā Ibn Habaš Ibn Amirāk al-Suhrawardīin, nasceu em Suhraward, ao sul de Zenjān e oeste de Soltānie, na província de Jabal, região da antiga Média, ao noroeste do Irã $^{19}$, exatamente no Curdistão persa. Essa região era populosa e influente. Homem misterioso, sua própria data de nascimento é ainda hoje motivo de controvérsias. Henry Corbin fixa a data de seu nascimento em 549 H./ 1155 d.C. ${ }^{20}$; Šahrazūri, biógrafo de Suhrawardī, a coloca em 562 H./ 1166 d.C. Todavia, há relatos que afirmam que na data de sua morte (586-8 H. /1090-92 d.C.), Suhrawardī contava com cinquenta anos incompletos. A tradição išrāqū, porém,

\footnotetext{
${ }^{18}$ Não confundir com Abu'l-Najīb al-Suhrawardī (m. 563 H./1167-8 d.C.), aluno de Aḥmad al-Ġazāli, irmão do famoso Ġazāli; asceta original e de grande atividade, nascido em 490 H., residiu na sua infância em Bagdá; aprendeu os hadīṭ em Ișfahān. Abraçando o ascetismo, voltou a habitar em Bagdá em estado de pobreza voluntária, exercendo a função de carregador de água. Começou a ensinar com sucesso no oeste do Tigre, fundando escolas. Em 558 H., ele esteve em Bagdá, com a intenção de ir em peregrinação para Jerusalém; não podendo, porém, executar seu desejo por conta das Cruzadas. Estabeleceu-se em Damasco, ocupado em ensinar hadițs. Não confundir também com o sobrinho deste, Šihāboddīn Abū Hafs 'Omar al-Suhrawardī (m. 632 H./1234-5 d.C.), célebre sufi de Bagdá, descendente de Abū Bakr e companheiro do célebre fundador de ordem 'Abd al-Kādir al-Djīlāni; nasceu em Suhraward em 539 H. Pertencia ao rito šafita. (cf. CARRA DE VAUX. "La Philosophie Illuminative (Hikmet el-ichraq), d'après Suhrawerd Meqtoul" apud SEZGIN, Fuat. As-Suhrawardī Shihäbaddīn Yahyā ibn Habash. Frankfurt am Main: Institute for the History of Arabic-Islamic Science at the Johan Wolfgang Goethe University, 2000, pp.1-31 [pp.63-93], p.4 [p.66], nota 1).

${ }^{19}$ A Pérsia era o centro do Império sassânida que, em 650 d.C., sem oferecer grande resistência, caiu sob poder árabe. A maior parte da população seguia o zoroastrismo. Os zoroastristas foram considerados pelos muçulmanos como dimis, ou seja, adoradores do Deus único - não sendo, portanto, idólatras -, o que os colocava em situação semelhante aos povos do Livro (judeus e cristãos). Em pouco tempo, a maioria da população urbana converteu-se ao islã; a população rural, porém, permaneceu fiel ao culto dos antigos persas. Ocorreram, nos séculos IV-V H./ IX-X d.C., tentativas de rebelião dessa população rural contra o domínio árabe. Era um movimento intelectual, religioso e social de renascimento da Pérsia pré-islâmica denominado šu ubiyyah. Tal movimento se estendera nas cidades, onde mesmo os persas muçulmanos começaram a resistir ao domínio árabe. Também nas cidades, assistiu-se a uma grande produção intelectual persa - bastante arabizada - em língua árabe. Contemporaneamente, acontece uma importante renovação do maniqueísmo. Nos séculos IV-V H./ XXI d.C., uma forte reação árabe acabou por abafar tais insurreições. O maniqueísmo, grosso modo, foi desde o aparecimento do islã, estigmatizado e interdito. Entrementes, a cultura persa islamizada tomou a dianteira do pensamento islâmico oriental; o mazdeanisno, o maniqueísmo e o cristianismo (principalmente a Igrejasiríaco-oriental, conhecida como assiro-caldeia ou mais vulgarmente como "nestoriana") conheceram um novo período de florescimento e de expansão (os maniqueus e os cristãos nestorianos chegaram ao interior da China). A resistência zoroastrista e maniqueísta acabou por se refugiar nas montanhas de Daylam, de Māzanderān e do Ādarbāyjān (Azerbaijão). Após a invasão mongol no século VII H./ XIII d.C., o nestorianismo cessou sua expansão, o maniqueísmo praticamente desapareceu e uma parte considerável da população mazdeana migrou para a Índia (migrações essas que ocorreram desde o século IV H./ X d.C.). (cf. CORBIN, Henry. En Islam iranien: aspects sperituels et philosophiques, Tome II - Sohrawardī et les Platoniciens de Perse. Paris: Gallimard, 1971).

${ }^{20}$ CORBIN, Henry. op. cit. p. 12.
} 
preferiu a opção de que Suhrawardī falecera aos 38 anos (lunares) de idade - 36 anos solares.

Suhrawardī, ainda criança, estudou em Marāgàh, na divisa com o Azerbaijão (Azerbaijão), próximo a fortes e organizadas comunidades zoroastristas e maniqueístas. Lá teve por mestre o médico, matemático, jurista e lógico Majd al-Dīn al-Jīlli ${ }^{21}$. Este fora também mestre de Fahr al-Dīn al-Rāzî̀ ${ }^{22}$.

Atraído pelo ensino de Faḩr al-Dīn al-Mārdīnī, matemático, médico e comentador do pensamento aviceniano, Suhrawardī mudou-se para Mardin (Anatólia). De acordo com todos os seus biógrafos, Suhrawardī tinha sólida formação como médico e físico, se destacando, no entanto, em seu domínio da matemática, por seu interesse pela lógica e pelo amor a essas duas disciplinas - curiosamente, não escreveu nenhuma obra sobre matemática, concentrando-se suas investigações em lógica. Posteriormente, retornou à Pérsia, a Ișfahān precisamente, cidade em que Ibn Sīnā desenvolvera sua atividade durante anos. Lendo os escritos deixados por Suhrawardī se percebe o quanto leu e estudou a obra de Ibn Sīnā. Em certo sentido, Suhrawardī entendeu a si mesmo como um continuador de Ibn Sīnā, incorporando aquilo que ele considerou esquecido pelo primeiro (Platão, Aristóteles - não o Aristóteles dos peripatéticos, mas o "verdadeiro" -, Hermes, Asclépios, Pitágoras e Zoroastro) e, dessa perspectiva, interpretou a filosofia aviceniana ${ }^{23}$. Ao que conta Šahrazūri, Suhrawardī estudou as obras de ${ }^{c}$ Umar ibn Sahlān Al-Sāwaj̄̄ (m. 539 H./ 1145 d.C.),

${ }^{21}$ CARRA DE VAUX. op. cit., p. 4 [p.66].

${ }^{22}$ Eminente representante do kalām (ciência da palavra ou teologia muçulmana), que pôs grande confiança nos recursos dialéticos herdados dos filósofos gregos (cf. nossa "Introdução", pp. 8-9). Embora de temperamento forte, procurou, em sua teologia, conciliar as diferentes escolas, tendências e seitas no islã. Esforçou-se por conciliar, por exemplo, mutazilismo e ašarismo, islã ortodoxo e xiismo, Ibn Sīnā e kalām. Sobre Rāzi enquanto filósofo, ler ARNALDEZ, Roger. Fakr al-Dîn al-Râzî, commentateur du Coran et Philosophe. Paris: Vrin, 2002, pp.131-254. Autor de uma obra de crítica à lógica aviceniana, chamada Livro das Buscas Orientais (Kitāb al-Mašriqiyyīn), em dois volumes, compreendendo três livros. O primeiro trata de lógica, o segundo sobre as substâncias e os acidentes, o terceiro sobre questões teológicas e filosóficas, na tentativa de conciliação do kalām e da falsafa. Ao que parece, Rāzī e Suhrawardī tinham notícias um do outro e ambos se admiravam; mas havia uma série de reservas mútuas. Sobre as controvérsias de Suhrawardī com Rāzi vale a pena ler o trabalho de Paul Kraus, Les “controverses” de Fakroddīn al-Rāzì (Bulletin de l'Institut d'Égypte XIX, 1937), p.164, $\mathrm{n}^{\circ} 4$. Kraus assinala uma correspondência entre as seis etapas da vida contemplativa na obra de Rāzī Kitāb Lawāmic al-bayynāt e as sequências adotadas em A iniciação de Simorg̀ de Suhrawardī. Sobre a lógica de Rāzī vale a pena ler STREET, Tony. "Fuhraddīn Ar-Rāzī’s critique of Avicennan Logic" in PERLER, Dominik \& RUDOLPH, Ulrich. Logik und Theologie: das Organon im Arabischen und im lateinischen mittelatter. Leiden-Boston: Brill, 2005, pp.99-116.

${ }^{23}$ FAKRY, M. Histoire de la philosophie islamique. Paris: Cerf, 1986, p.323. 
autor de um comentário sobre a Epístola dos Pássaros de Ibn Sīnā - Suhrawardī traduziu tal comentário do árabe para o persa. Teve por companheiro de estudo o matemático e lógico Zāhiir al Farīsī, cuja inovação na lógica consistiu em abandonar as nove partes em que se estão divididas no Organon de Aristóteles, a favor de uma lógica mais simples - a tentativa de superar a lógica aristotélica está também presente no Livro da Sabedoria da Iluminação.

Suhrawardī retornou para a Anatólia. Acabou sendo bem acolhido em Diyār Bakr, sudeste da Anatólia, frequentando a corte dos seldjúcidas de Rūm. Ele mesmo dedicou a 'Imādoddīn Qarā Arslān, emir de Ḩarput, seu Livro das Lembranças dedicadas à 'Imādoddin ${ }^{24}$. Ao que parece ${ }^{25}$, Suhrawardī visitou Harrān ${ }^{26}$, Antalya, Nusuybin e Urfa, no nordeste da Síria.

Não se sabe exatamente o porquê Suhrawardī resolveu se mudar, em 579 H./ 1183 d.C., para a cidade síria de Alepo. Esta, exatamente em 1183 d.C., caiu sob o domínio de Șalāḥ al-Dīn Yūsuf ibn Ayyūb ${ }^{27}$. Esse chefe militar de origem curda foi o responsável pelo triunfo do sunismo no Egito, aniquilando a grande ameaça ao califado de Bagdá, que fora o califado fatímida. Graças a Șalāḥ al-Dīn, o Egito voltou a fazer parte do califado abássida. Uma vez dissipada a ameaça ismaelita, Șalāḥ al-Dīn se voltou contra os domínios francos, objetivando reconquistar Jerusalém e expulsar os francos do continente asiático. Șalāh al-Dīn decidiu cercar a Palestina, conquistando para si os territórios sírios. Alepo havia imposto certa resistência à conquista de Șalāḥ al-Dīn . Este, uma vez conquistada a cidade, nomeou seu filho al-Malik al-Zāhir alĠāzī como governador de Alepo.

Chegando incógnito à cidade, Suhrawardī se hospedou na madrasa Halawīyya, a escola de direito hanafi mais importante de Alepo. De acordo com $\breve{S}_{\text {ahrazūri }}{ }^{28}$, Suhrawardī pertencia à escola de direito $\check{s} \bar{a} f i^{c} i$, patrocinada por Malik al-

\footnotetext{
${ }^{24}$ Obra em árabe que o próprio autor traduziu para o persa, Alwāh-e 'Imādi. Essa versão persa foi publicada por S. H. Nars em Ouvres Philosophiques et Mystiques III, Académie Imperiale de Philosophie, Teerã, 1977.

${ }^{25}$ CORBIN, H. op. cit., pp.13-14.

${ }^{26}$ A cidade era famosa por ser onde se refugiaram os filósofos expulsos de Atenas (em 529 d.C, pelo imperador bizantino Justiniano), e as outras três por haverem sido, antes da chegada do islã, importantes centros de recepção da tradição hermética.

${ }^{27}$ Trata-se do famoso Saladino da terceira cruzada.

${ }^{28}$ CORBIN, H. Histoire de la philosophie islamique. Paris: Enciclopédie de la Pléiade, 1974.
} 
Zāhir e por Șalāḥ al-Dīn . Suhrawardī, em um debate, aniquilou dois dos mais ilustres mestres de direito da cidade, os irmãos Jahbal (um dos quais, Ṭahīr Ibn Jahbal fundou a tradicional madrasa Nurīyya). Sua reputação se espalhou rapidamente e logo o filho de Șalāḥ al-Dīn começou a assistir aos debates entre Suhrawardī e os ulemás. Desde então, brotou uma forte amizade entre Suhrawardī e Malik al-Zāhir. Este, ainda em 1183, retornou a Damasco, passando Alepo a ser administrada por seu tio al-Malīk alAdīl, irmão de Ṣalāḥ al-Dīn . Não se sabe se Suhrawardī acompanhou al-Malik em sua estada em Damasco, mas se sabe com certeza que no momento do retorno de Malik alZāhir para governar Alepo em 582 H./ 1186 d.C., Suhrawardī aí estava. Também é, de acordo com o próprio Surhawardī ${ }^{29}$, em 1186 d.C. que foi escrita a sua obra principal, o Livro da sabedoria da iluminação.

Desde sua estada em Alepo $^{30}$, os ulemás pediram sua execução. Por que tamanho ódio contra o filósofo? O que levou Șalāḥ al-Dīn, o paradigma do medievo latino de guerreiro justo, a ordenar sua morte? De acordo com os testemunhos de cronistas da época, Suhrawardī foi acusado de "heresia" e de "ateísmo", de infidelidade e de incredulidade. $O$ fato de seu interesse pelo conhecimento da sabedoria antiga, pré-islâmica, faria dele um corruptor da fé, assim como o fato dele negar $\left(t a^{\prime} t \bar{l} l\right)$ a realidade dos atributos de Deus. Rivalidades entre juristas e doutores era algo bastante comum, mas não deveria necessariamente conduzir à pena capital, mais ainda vinda pela mais alta autoridade. A acusação de ateísmo e de incredulidade era rótulo comum aos filósofos. Ġazali em seu Tahāfut al-Falāsifa (Derrocada dos filósofos) diferenciou-os entre materialistas (dariyyūn), naturalistas (tabī iyya) e teístas (ilāhiyyūn). Para Ġazālī, os teístas conseguiram refutar os materialistas e os naturalistas, negando, porém, as verdades fundamentais do islã. Entre outras coisas, segundo Ġazālī, os filósofos ditos teístas negariam a afirmação da eternidade do

\footnotetext{
29 "Eu concluo a composição no final do mês de Ğomādā II do ano 582 da Ajira, o dia onde sete planetas se acham em conjunção no signo de Libra; terminei ao fim do dia" SUHRAWARDĪ. Kitāb Hikmat al-Išrāq parágrafo 279 (tradução francesa, Livre de la sagesse orientale, commentaires de Quoṭboddin SHÎRÂZÎ e Mollâ ȘADRÂ, tradução e notas por Henry Corbin, edição e introdução por Christian Jambet. Paris: Verdier, 1986, p.231; tradução em inglês: The Philosophy of Illumination, A New Critical Edition of the Texto of Hikmat al-ishrāq with English Translation, Notes, Commentary, and Introduction by Jonh Walbridge e Hossein Ziai. Provo: Brigham Young University, 1999, p. 162). Esta data corresponde a 15 de setembro de 1186.

${ }^{30}$ Haveria Suhrawardī acompanhado al-Malik à capital ayúbida de Damasco, o que ajudaria a explicar a convicção de Șalāḥ al-Dīn em condená-lo à morte?
} 
mundo, a negação do conhecimento de Deus sobre os particulares e a doutrina da ressurreição da carne ${ }^{31}$. A acusação de negar os atributos divinos era comum contra os teólogos $\mathrm{mu}^{c}$ tazilitas, que ao sustentarem a unidade e a monarquia absoluta de Deus, negavam quaisquer formas de antropomorfismos. Tal acusação era feita também contra os pensadores ismaelitas, ainda que esses não se reconhecessem nessa acusação.

Outra acusação endereçada a Suhrawardī refere-se à própria possibilidade de Deus enviar novos profetas. Pelos testemunhos biográficos, não havia razões para negar que o filósofo era um muçulmano piedoso, um exemplo na prática de suas obrigações regulares. "Em verdade, não conheço, pois, qualquer texto de Suhrawardī em que se proponha que Deus possa criar um profeta, um nabī, cada vez que Deus queira, isto é, depois da vinda daquele que foi, com toda a razão, chamado de 'Selo da Profecia', ${ }^{32}$.

Chega-se aqui a um dado biográfico importante. Não se pode afirmar com segurança se Suhrawardī seguia - ou ao menos simpatizava - com o xiismo, e mesmo com o sufismo, na sua versão clássica, ao menos. As divisões no interior da comunidade islâmica não eram claras e bem estabelecidas. Há razões para excluir a possibilidade de Suhrawardī haver professado o xiismo na sua versão ismaelita nizār $\bar{l}^{-33}$ da Pérsia. Da mesma maneira é possível excluir Suhrawardī dos sufis clássicos, ainda que Suhrawardī mostrasse ter conhecimento das tradições e práticas espirituais sufis, sobretudo nos seus escritos persas. Certas doutrinas dos "antigos" que fazem parte integrante da doutrina iluminacionista estão também presentes no sufismo clássico. $^{34}$

\footnotetext{
${ }^{31}$ CRUZ-HERNÁNDEZ, Miguel. Historia del pensamiento en el mundo islámico. 1. Desde los orígenes hasta el siglo XII en Oriente. Madri: Alianza, 2000.

32 Afirmação de Henry Corbin em seu livro : En Islam iranien: aspects sperituels et philosophiques, Tome II - Sohrawardī et les Platoniciens de Perse. Paris: Gallimard, 1971, p.15.

${ }^{33}$ Trata-se do grupo ismaelita mais forte e atuante na Pérsia e no Azerbaijão. Sabe-se que os nizārīs exterminaram em 1142 d.C. uma seita pseudo-ismaelita do Azerbaijão, cujo erro foi, aos seus olhos, o de haver incluído os reis da Pérsia na linha dos imãs legítimos.

${ }^{34}$ É o caso do célebre par de Empédocles amor/discórdia ( $\left.\varphi \imath \lambda i \alpha / v i \bar{\kappa} \kappa \varsigma\right)$ que os autores árabes conhecem sob a forma de amor/dominação, que o aproxima da doutrina de Hallāj sobre o amor contemplativo. Olhando de mais perto, se percebe, porém, que Hallāj, de acordo com Daylamī, professa uma doutrina que faz do amor, da dominação e de todos os outros atributos divinos, formas (șūras) inerentes à própria essência divina (Daylamī. A Treatise, p. 40, n.11 apud LANDOLT, H., op. cit., p.243.), ao passo que
} 
Em uma carta de Ṣalāḥ al-Dīn ao seu filho, o sultão lhe informara que seus juízes haviam condenado Suhrarawardī como herege e inovador, e deveria ser preso por isso. Malik al-Zāhir recusou-se a obedecer ao decreto paterno. Em uma segunda carta, o sultão lhe informou que seus juízes condenaram Suhrawardī à crucificação. Malik al-Zāhir, mais uma vez, se recusou a condená-lo. Finalmente, numa terceira carta, Șalāḥ al-Dīn manifestou sua ira para com Malik al-Ẓāhir, ameaçando-o de depô-lo como regente de Alepo e de excluí-lo como herdeiro. Como Suhrawardī se recusava a fugir, Malik al-Zāhir cedeu aos desejos paternos e condenou o filósofo à morte. A data gira em torno de 586-8 H./1090-92 d.C. Ibn Jallijan a fixa em 29 de julho de 1191 d.C. O que se sabe com certeza é que Suhrawardī foi condenado à morte por ordem de Șalāḥ al-Dīn. Suhrawardī passou à história como al-šayh al-maqtūl (o mestre condenado, executado), al-šayh al-šahīd (o mestre "mártir", testemunha verídica) e, como ainda hoje é conhecido, al-šayh al-išrāq (o mestre das luzes).

Por que Suhrawardī, um jovem natural do Curdistão persa, chegado a Alepo por volta do ano 579 H./ 1183 d.C. - um ano após a cidade haver sido confiada ao jovem príncipe Malik al-Z̄āhir - e que conseguiu, em sua chegada, um lugar dentro da corte, foi executado em poucos anos? Por que um pobre rapaz, que se vestia como sufi, representaria uma ameaça para o grande sultão Șalāḥ al-Dīn? Por que o mesmo temeria um jovem filósofo e um de seus juízes, al-Fāḍil, escreveria uma carta exigindo a sua morte?

O ano 586 H./ 1191 d.C. foi importante. Durante aquele ano, as batalhas entre cristãos e muçulmanos pela Terra Santa se tornaram mais intensas e o Rei Ricardo Coração de Leão desembarcou em São João de Acre. Em 586 H./ 1191 d.C., Șalāḥ alDīn estava concentrado na guerra contra os cruzados pelo controle da região, enquanto tentava superar a espionagem e intriga política exercida por Rašīd al-Dīn Sinān, "o velho Homem da Montanha". Șalāḥ al-Dīn era cônscio de que havia intrigas contra o seu nome junto à corte califal; ele tinha também receio de uma insurreição no

para Suhrawardī não há "formas" na essência divina e é a dominação da irradiação (šurūq) que caracteriza a relação de cada luz superior com a luz que lhe é inferior, a qual responde com uma relação de amor pelas luzes superiores (SUHRAWARDĪ, op. cit., par. 1999.143, 147-148, 152, 216.); para Suhrawardī, se trata de uma concepção hierárquica do ser que corresponde perfeitamente ao que se encontra nos mesmos termos de Empédocles no ismaelita Abū Ya ${ }^{c} q u ̄ b$ al-Sijistān̄i (século X d.C.) (LANDOLT, Hermann, op. cit., p.244.). 
Egito, visto fazer pouco tempo que o califado fatímida havia sido destruído no Cairo. Claramente, Șalāḥ al-Dīn tinha preocupações mais sérias do que perseguir um filósofo errante. Talvez estivesse preocupado com a influência exercida por Suhrawardī sobre seu filho Malik al-Zāhir. Este poderia, sob orientação de Suhrawardī, tornar-se um tipo de "governante sábio" e "rei legítimo" a la Suhrawardī, uma versão árabe do reifilósofo de Platão, reinaugurando a era dos reis sábios da Pérsia antiga.

Bahā’ al-Dīn Ibn Šaddād, famoso biógrafo de Șalāḥ al-Dīn e qāọ̄ de Jerusalém, pode haver desempenhado importante papel na execução de Suhrawardī, alertando Șalāh al-Dīn sobre as implicações políticas dos seus ensinamentos filosóficos. Ibn Šaddād, nascido em Mossul em 539 H./ 1145 d.C. e professor na Niẓāmiyya em Bagdá por quatro anos, passou a trabalhar para Șalāḥ al-Dīn em 584 H./ 1188 d.C., sendo um companheiro próximo do sultão até a sua morte em 589 H./ 1193 d.C., momento em que ele se tornou conselheiro de Malik al-Zāhir - cargo ocupado por al-Suhrawardī antes de sua morte. Ibn Šaddād fala sobre Suhrawardī em uma seção em sua biografia intitulada "A menção de que vimos a respeito de sua [de Șalāḥ al-Dīn ] estrita observância aos princípios religiosos e sua reverência para com os assuntos da $\breve{S} a r^{-c} a h^{\prime 35}$. Como um exemplo do fervor religioso de Șalāḥ al-Dīn e na defesa da lei religiosa, Ibn Šaddād cita a ordem de execução de Suhrawardī:

Șalāh al-Dīn tinha grande respeito pelas práticas religiosas. Ele esperava a ressurreição corporal [...] e confirmava tudo o que era de acordo com a lei. [...] Detestava os filósofos, aqueles que negavam os atributos de Deus, aqueles que acreditavam na eternidade do tempo e do espaço e quem quer que fosse, filósofo ou não, que se opusesse à Lei. Ordenou a seu filho, governante de Alepo, al-Malik al-Z̄āhir - Deus glorifique-o em suas vitórias - para levar à morte um jovem chamado al-Suhrawardī que havia ascendido [a uma posição influente em Alepo]. Pois foi dito sobre ele que se opôs às leis religiosas, considerando-as ab-rogadas. Assim, o filho de Șalāḥ al-Dīn capturou alSuhrawardī quando soube das notícias a respeito dele, informou o sultão, e

\footnotetext{
${ }^{35}$ IBN ŠADDĀD, Nawādir al-Sulțāniyyah, 7, in ZIAI, Houssein. "Source and Nature of Authority: A study of Suhrawardī's Illuminationist Political Doctrine." In, The Political Aspects of Islamic Philosophy, edited by Charles Butterworth. Cambridge: Harvard University Press, 1992, pp. 304-344, p. 338.
} 
ordenou que ele fosse morto. Ele foi crucificado por um tempo e [depois] morto ${ }^{36}$.

A implicação dessas palavras é mostrar quais eram as acusações contra Suhrawardī. Além disso, parte do que poderia contribuir para tal reputação é a crença de que Suhrawardī tinha poderes "mágicos". Ibn Abī Ușaybi a constata que Suhrawardī tinha a reputação de ser um grande conhecedor da ciência da magia ${ }^{37}$. "Alguém que conhecia e informava sobre os divinos segredos" é como Šahrazūrī descreve Suhrawardīi ${ }^{38}$, mas, em seguida passa a precisar que a autoridade dos antigos sábios e filósofos deve ser considerada por excelência na filosofia iluminacionista. Um historiador, tempos mais tarde, al-Dahabī (m.748 H./ 1347 d.C.), também opta por destacar de Suhrawardī o seu conhecimento da sabedoria antiga, inigualável em seu tempo, menciona também que foi o primeiro em tal conhecimento e especifica que uma das principais acusações contra ele era a de haver corrompido a fé do filho de Șalāḥ al-Dīn, Malik al-Zahirir ${ }^{39}$.

Em suma, temos várias e conflitivas abordagens sobre a vida - e, sobretudo a morte - de Suhrawardī. Chamado de feiticeiro por alguns, designado como o maior "sábio divino" do seu tempo, por outros. Um espectro tão amplo de opiniões é difícil de se encontrar em algum filosofo árabe antes dele. Mesmo que com 36 ou 38, 40 ou 50 anos de idade, e com todos os acontecimentos que marcaram sua vida - e, em particular, sua morte - Suhrawardī pode escrever uma obra considerável. Lendo o Prólogo e o Livro V do Livro da Sabedoria da Iluminação, vê-se que Suhrawardī fala de que a ele estava associado um grupo de companheiros, a quem dedicou sua referida obra. Quando da sua condenação à morte, ao que tudo indica, seus discípulos e amigos se dispersaram ${ }^{40}$.

\footnotetext{
${ }^{36}$ Ibid., 10.

${ }^{37}$ Ibn Abī Ușaybicia, Tabaqāt al-Ațibbā', 642-643, in ZIAI, op. cit.

${ }^{38}$ Cf. Nuzhat al-Arwāh, 2:119-120, in ZIAI, op. cit.

${ }^{39}$ Cf. al-Dahabī, Kitāb al- Ibār fì Hadar man Gabar, ed. Șalāḥ al-Dīn al-Munajjid (Kwait: Wizarāt alIršd wa al-Ta' $\left.{ }^{\mathrm{c}} \overline{\mathrm{i}} \mathrm{m}, 1963\right)$, 4:263-265 in ZIAI, op. cit.

${ }^{40} \mathrm{Da}$ mesma forma, nenhum de seus biógrafos do próprio século VI H./ XII d.C. em que viveu Suhrawardī são conhecidos, a exceção de alguns poucos relatos fragmentários contemporâneos sobre ele, feitos por seu colega Ibn Rakika, também aluno de Mardīnī. Outro importante biógrafo do filósofo, Ibn Abi Usayb'ia, nasceu depois da morte de Suhrawardī. Não obstante, o matemático e filósofo ${ }^{\mathrm{C}} \mathrm{Abd}$ al-Latīf al-Baġdadi (m. 1231 d.C.), aluno do célebre matemático de Mossul, Zamal al-Dīn Yūnus (m.
} 


\section{A obra de Suhrawardī e sua organização}

A obra de Suhrawardī é imensa, apesar da morte prematura de seu autor. Baseando-se no prefácio do Kitāb hikmat al-išrāq e, provavelmente pelos escritos de Šahrazūrī e pelo comentário à referida obra de Qutb al-Dīn Širāzī, Louis Massignon ${ }^{41}$ distinguiu os escritos de Suhrawardī nas três fases seguintes de sua vida: a primeira, a fase de sua juventude, se caracteriza por um "išraquismo" puro. É nessa época que Suhrawardī haveria escrito al-Alwāh al- ${ }^{c} i m a \bar{d} d i y y a$, Hayākil al-nūr e outros tratados místicos. A segunda fase corresponde a de seu peripatismo, durante a qual escreveu: al-Talwīhāt, al-Lamahāt, al-Muqawamāt, al-Mašāric wa-l-muṭārahāt e al-Munajat. Enfim, a terceira fase em que predomina um išraquismo sob influência avicenoplatônica, na qual compôs o Hikmat al-išrāq, a Kalimat al-tașawwuf e I'tiqad alhukuma.

Henry Corbin ${ }^{42}$ criticou tal maneira de ver, fazendo valer sérias dificuldades que se levantam. A título de exemplo, al-Alwāḥ al-imadiyya é muito provavelmente contemporâneo de Hikmat al-Išrāq e dos grandes tratados "dogmáticos". Ademais, Hayakil al-nūr simplifica as doutrinas mais características de Hikmat al-išrāa . Enfim, a composição de rasa'il utilizando mitos e símbolos com uma finalidade essencialmente iniciática, pressupõe, segundo Corbin, uma intensão firmemente išraqī. Corbin pensa também que "as obras discutindo ou emprestando a dialética peripatética não implicam uma adesão filosófica ao peripatetismo, como tal”43. Assim, chega à conclusão de que em Suhrawardī há uma "unidade de intenção" que lhe permite, sem que se possa falar propriamente em evolução ou de períodos em sua vida, se expressar em formas variadas. Corbin, assim, propõe uma classificação de, por assim dizer, ordem doutrinal, feita da seguinte maneira:

a) O sistema dos grandes tratados dogmáticos: al-Talwīhāt (1), al-Muqāwamāt (2), muțārahāt (3) e Hikmat al-išrāq (4).

1242 d.C.), mostra haver feito contato com a obra de Suhrawardī. (CORBIN, H. Histoire de la philosophie islamique. Paris: Enciclopédie de la Pléiade, 1974).

${ }^{41}$ Recueil de textes inédits concernant l'histoire de la mystique en pays d'Islam, Paris : 1929, p.113.

${ }^{42}$ AS-SUHRAWARDI, Opera Metaphysica et mystica, vol. I. Istambul: 1945, p.VII.

${ }^{43}$ Op. Cit., p.XIII. 
b) A obra menor (opera minora), dogmática também, mas que insistem sobre uma parte ou um grupo de temas: al-Alwāḥ al- ${ }^{c}$ imadiyya, Bustan al-qulub, Hayakil al-nūr, I'tiqad al-ḥukuma, Kalimāt al-tașawwuf, Kašf al-ġița', al-Lamahāt e Partaw-Nameh.

c) Os rasā'il em forma de romances de iniciação e recitos simbólicos, todos escritos em persa.

d) Al-Waridat wal-Taqdisa que Corbin denomina como "Livro das Horas", onde haveria um hino para cada dia da semana.

Muhammad Abū Rayyan, professor na Universidade de Alexandria, consagrou sua tese de doutorado em Paris às Origens da filosofia de išrāq ${ }^{44}$, discutindo em um capítulo especial as duas posições precedentes. Abū Rayyan não pensa que se pode estabelecer uma coordenação orgânica entre os diversos livros e tratados de Suhrawardī ${ }^{45}$. Apoiando-se nas palavras do próprio Suhrawardī, este começou já cedo a escrever as ideias contidas no Hikmat al-Ǐsrāà . Impedido por suas numerosas viagens, de concluir essa obra - e muitas vezes nem mesmo querendo concluí-la - Suhrawardī redige, por solicitação de seus amigos, outros tratados, como: al-Lamahāt, al-Talwīhāt, al-Muqawamat, al-Mutahara e al-Hayākil, sem por isso deixar de desenvolver as ideias que estarão mais tarde no Hikmat al-Ǐ̌r $\bar{r} q$. Pode-se, então, sustentar que Suhrawardī concebeu a doutrina do Hikmat al-Išrāq antes de haver redigido esse livro e que ao redigir os outros tratados, ele não quis fazer uma exposição completa e sistemática de sua doutrina filosófica, mas insistir sobre este ou aquele aspecto sem se atingir a densidade que se encontrará no Hikmat al-išrāq. Em outras palavras, os outros tratados dão, segundo Abū Rayyan, exposições parciais e simplificadas para uma iniciação à sua doutrina filosófica (nawāḥi mubassața lilmadhal), a Hikmat al-išr $\bar{a} q$ oferece uma exposição completa, contendo, em uma forma compacta e condensada - e mais densa - todos os aspectos de sua filosofia.

\footnotetext{
${ }^{44} \mathrm{O}$ mesmo autor editou um texto árabe, sob o título: Usul al-falsafa al-išraqiyya inda Šịab al-Dīn Suhrawardī. Beirute: Dar al-talaba al- ${ }^{\mathrm{C}}$ Arab, 1969. Georges Anawati considera a posição de Abū Rayyan muito mais razoáveis do que as de Massignon e de Corbin ( La notion de wujud dans le Kitab Al-Mashari' wa'l-Mutarahat de Suhrawardi » Memorial Shihab al-Din Suhrawardi a l'occasion de Huitième Centenaire de as mort, Cairo, 1974).

${ }^{45}$ Cf. Op. Cit., pp.66-67.
} 
Outra abordagem diferente tanto da de Massignon como da de Corbin, foi levantada por John Walbridge e, principalmente, por Houssein Ziai ${ }^{46}$, que consideram o Hikmat al-išrāq precisamente a obra de maturidade e a culminação do projeto filosófico de Suhrawardī. Para Ziai ${ }^{47}$, os mais importantes trabalhos são al-Talwīhāt, Muqāwamāt, al-Mašāric wa 'l-muțārahāt e, principalmente, Kitāb hikmat al-išrāq. Estes textos constituem o corpo integral da filosofia de Suhrawardī. Assim, segundo Ziai, não se pode levar a cabo um estudo da metafísica de Suhrawardī sem antes realizar um estudo de sua lógica e as implicações que desta decorrerem. Assim, seguindo a ordem estabelecida por Šahrazūrī, Walbridge e Ziai estabeleceram essa seguinte ordem nos escritos de Suhrawardī:

a) Escritos juvenis.

b) Trabalhos de caráter contemplativo, escritos em árabe e em persa, nos que se incluem orações, invocações e alegorias.

c) Escritos filosóficos de caráter peripatético que formam um compêndio e que incluem al-Talwīhāt, Muqāwamāt e al-Mašărici wa 'l-muțārahāt.

d) O próprio Kitāb hikmat al-ǐ̌r $r a ̄ q$.

Nesse esquema, os textos de caráter contemplativo se consideram trabalhos elementares e populares ao público em geral, não determinantes no projeto do autor.

$\mathrm{Assim}^{48}$, se pode perceber Suhrawardī como um autor de um sistema filosófico que pretende aperfeiçoar o método de filosofia e de ciências de sua época. O maior impacto da filosofia de Suhrawardī foi sentido na epistemologia. Isso ficará mais evidente quando analisarmos a obra em questão, i.e, o Kitāb hikmat al-išrā $q^{49}$.

\footnotetext{
${ }^{46}$ Os tradutores para o inglês de Hikmat al-Išrāq The Philosophy of Illumination: A New Critical Edition of the Text of Hikmat al-Išrāq with English Translation. Notes, Commentary and Introduction by JonhWilbridge e Hossein Ziai. Provo: Brigham Young University Press, 1999.

${ }^{47}$ A visão de Ziai pode ser vista em seu artigo "Al-Suhrawardī, Shihāb al-Dīn" em Encyclopedia of Islam, Second Edition, qv, pp. 781-784. (A.30).

${ }^{48}$ Distanciamo-nos criticamente tanto das posições de Massignon como das de Corbin. Parece-nos que a posição de Abū Rayyan, ratificada por Anawati, de um lado, e as de Walbridge e de Ziai, de outro, não se contradizem. Adote-mo-las, pois. Com efeito, o trabalho de Ziai, em seus diferentes livros e artigos, e, principalmente, a interpretação do orientalista e historiador da filosofia Max Horten - em seu „Die Philosophie der Erleuchtung nach Suhrawardī $\left(1191^{+}\right)^{\prime \prime}$ - nos marcaram profundamente na constituição deste trabalho.

${ }^{49}$ A tradução do título "Kitāb hikmat al-išrāq" é problemática e sujeita a debates. Uma tradução literal seria "Livro da sabedoria filosófica sob irradiação do sol matutino" (cf. Landolt, Hermann. Les idées platoniciennes et le monde de l'image in DE SMET, Daniel; SEBTI, Meryem \& DE CALLTA,
} 


\section{A genealogia da sabedoria}

\section{O prólogo do Livro da sabedoria da iluminação afirma que seu método,}

melhor ordenado, acessível e preciso para os que procuram sabedoria, é confirmado

pelas experiências dos antigos, a quem Suhrawardī se refere desse modo:

Godefroid. Miroir et savoir : la transmission d'un thème platonicien, des Alexandrins à la philosophie arabo-musulmane. Louvain-la-Neuve : Leuven University Press, 2008, pp.233-250, p.233). Corbin preferiu traduzir hikmat como "teosofia". Com efeito, se se entende "teosofia" como conhecimento intuitivo que leva a unidade com o divino e/ou divindade, a obra de Suhrawardī poderia ser chamada de teosofia. Ora, se assim o fosse, o platonismo, o neopitagorismo, o neoplatonismo, ou o estoicismo, o aristotelismo medieval, ou mesmo o cartesianismo e diversas correntes da filosofia moderna, deveriam também ser denominados "teosofia"; entretanto, não são chamadas de "teosofia", mas de "filosofia", além do fato de que teosofia adquiriu outro sentido a partir do século XVIII d.C. Ademais, Suhrawardī tem o objetivo de compor um novo sistema filosófico, sendo inadequado descrever hikmat pelo uso de termos filosóficos não técnicos, como "teosofia", ou mesmo "filosofia transcendental", "teosofia transcendetal", "sophia perennis". Por isso, rejeitamos a solução apresentada por Corbin. Ziai prefere traduzir hikmat como sabedoria ou como filosofia, a depender do contexto, e išrāq, às vezes como iluminação, às vezes como luzes. A título de esclarecimento, a hikmāt proposta por Suhrawardī não se pretende identificar com a "filosofia demonstrativa". A filosofia demonstrativa, para Suhrawardī, é o conhecimento discursivo, de grande importância, mas insuficiente para se atingir a hikmat. Desse modo, traduziremos hikmat por sabedoria. Da mesma maneira, a palavra išrāq não denota necessariamente o oriente geográfico; pode denotar o "oriente" enquanto "sol nascente". Nesse sentido, Cruz Hernandez preferiu traduzir por Livro da Sabedoria da Alvorada ou do Alvorecer. Tal tradução não nos parece ser a melhor. Com efeito, a ideia de uma filosofia oriental vem de Ibn Sīnā. Isto põe um problema. Permanece dele um livro intitulado Lógica dos Orientais (Mantiq al-Mašriq). Corbin lançou a hipótese que os comentários de Ibn Sīnā às obras de Aristóteles não representariam o seu pensamento pessoal e que é necessário procurar fora dessas obras a sua filosofia original. Entretanto, muitas pesquisas mostram que "oriental" deve ser entendido aqui no sentido geográfico, ou seja, os trabalhos de Ibn Sīnā são desenvolvidos sempre a leste de Bagdá (Cf. ARNALDEZ, op. cit., p.130). M.-A. Goichon chamou a atenção para a importância de Galeno, do exercício da medicina e talvez de fontes estoicas na formulação de Ibn Sīnā diferente da dos aristotélicos de Bagdá (Cf. GOICHON, na introdução à sua tradução do Kitāb al-Išarāt wa'l-lanhțūh, p.11 in PINÈS, S. op. cit., p. 327 [p.30] e GOICHON, "O Pretenso Esoterismo de Avicena no Relato Hayy Ibn-Yaqzan", Tradução e introdução de Christiane DAMIEN, em Tiraz Revista de Estudos Árabes e das Culturas do Oriente Médio. São Paulo: Programa em Língua, Literatura e Cultura Árabe - USP, 2009, n. 6, p.110-118.). Pinès lança uma hipótese interessante: a filosofia oriental de Ibn Sīnā não passaria de pretexto - em um contexto de rivalidade com os filósofos, sobretudo os siríacos, de Bagdá - sob a garantia de estar seguindo uma tradição mais antiga do que a grega, visto que os aristotélicos de Bagdá se reclamavam mais fiéis a Aristóteles e à tradição filosófica do Ocidente, pois as fontes da filosofia haveriam vindo dos gregos, do Ocidente. (PINÈS, op. cit., p.32). Seja o que for, Mantiq al-Mašriq deu história. São inúmeros os pensadores árabes que tentarão reconstituir a sua filosofia oriental. No exemplo de Rāzī, em seu Livro das Buscas Orientais (Kitāb al-Mabāhit al-Mašriqiyya) parece ser claro que se trata apenas do fato dele estar no oriente geográfico, pois ele critica Ibn Sīnā e não faz menção a Mantiq al-Mašriq. No que se refere a Suhrawardī, este não cita em suas obras o Mantiq al-Mašriq de Ibn Sīnā. No Kitāb hikmat al-išrāq, išrāq não denota oriente ( $m a \check{s} r i q$ ). Entende-se como o ato de iluminar ( $\check{s} r q$ ). Assim, traduziremos $i \check{s} r \bar{a} q$ como "iluminação". Desse modo, o título da obra em questão utilizado, de agora em diante, será: Livro da sabedoria da iluminação. No entanto, é preciso reconhecer que uma resposta definitiva é difícil, visto a semelhança entre "oriente" (mašriq) e "iluminado" (mušriq). Traduziremos o adjetivo isrāqū por "iluminacionista". Quanto à escola filosófica tributária a Suhrawardī, chamaremos de "iluminacionismo". 
Em tudo o que eu disse sobre a ciência das $\operatorname{luzes}^{50}$, fui assistido por aqueles que percorreram o caminho de Deus. Esta ciência é a mesma intuição do inspirado e iluminado Platão ${ }^{51}$, guia e mestre da sabedoria, e daqueles que estiveram antes que ele, desde a época de Hermes, o primeiro dos sábios, até a época do próprio Platão, incluindo vigorosos pilares da sabedoria, como Empédocles, Pitágoras e outros. As palavras dos antigos são simbólicas ${ }^{52} \mathrm{e}$ não estão abertas a refutação. As críticas feitas ao sentido literal de suas palavras fracassaram em se aplicar às suas reais intenções, pelo fato de que um símbolo não pode vir a ser refutado. Essa é também a base da doutrina oriental da luz e da obscuridade, que foi a essência dos sábios persas como Jāmāsp ${ }^{53}$, Frašoštra ${ }^{54}$, Bozorġmer ${ }^{55}$ e outros anteriores a eles. Não se trata da doutrina dos magos infiéis, nem da heresia de $\mathrm{Mani}^{56}$, tampouco da doutrina que leva a

${ }^{50}$ Quṭb al-Dīn ( Šarh hikmat, 16) comenta que a ciência das luzes lida com o primeiro princípio, os intelectos (celestes) e as almas. Inclui-se aí a maior parte da física, importantes aspectos da metafísica e, em geral, o que é conhecido por intuição. (V. Livre de la sagesse orientale, commentaires de Quoțboddin SHÎRÂZÎ e Mollâ ȘADRÂ, tradução e notas por Henry Corbin, edição e introdução por Christian Jambet. Paris: Verdier, 1986, p. 241, parágrafo 26 ;v. tb. The Philosophy of Illumination, A New Critical Edition of the Text of Hikmat al-ishrāq with English Translation, Notes, Commentary, and Introduction by Jonh Walbridge e Hossein Ziai. Provo: Brigham Young University, 1999, p. 170, note 5).

51 "Platão está de acordo com tudo o que o autor [Suhrawardī acaba de dizer], em seus livros Timeu e Fédon, e em outros tratados, o que está de acordo com o que foi atestado pela recitação de seus êxtases (macārij)". ("Deuzième partie : Commentaires de Qotboddîn Shîrâzî", Livre de la sagesse orientale, commentaires de Quoțboddin SHÎRÂZÎ e Mollâ ȘADRÂ, tradução e notas por Henry Corbin, edição e introdução por Christian Jambet. Paris: Verdier, 1986, p. 242).

${ }^{52}$ Quṭb al-Dīn (Šarh hikmat, 17-18) explica que "Hermes, o egípcio, e os gregos Empédocles, discípulo de Hermes e seu discípulo Pitágoras, Sócrates, discípulo de Pitágoras e seu discípulo, Sócrates, mestre de Platão, o selo da sabedoria (hătim abl al-hikmat al-dawqia)" (Id., parágrafo 31, p. 242) se expressaram em símbolos para imitar o próprio Criador e os profetas que deixaram livros, cujo ensinamento é eminentemente simbólico. Além disso, Quṭb al-Dīn lista quatro razões para o uso de símbolos pelos antigos: para aguçar a mente do leitor; para tornar o texto melhor apropriado tanto às elites como às massas; para ocultar doutrinas dos indignos e hostis a elas; e para separar os discípulos inteligentes dos estúpidos. (Id., parágrafo 32, pp. 243-244).

${ }^{53}$ Personagem semi-lendário da antiga Pérsia. Vizir do rei Vištaspa, o rei protetor de Zoroastro. Livros sobre alquimia e astrologia foram-lhe atribuídos nos tempos islâmicos.

${ }^{54}$ Trata-se de um dos primeiros mazdeanos mencionados no Avesta.

${ }^{55}$ Foi um vizir, da época sassânida, do século VI d.C., famoso por sua sabedoria. Livros de matemática e de astrologia também circularam com seu nome.

${ }^{56}$ Eis a forma como Quṭb al-Dīn apresenta a figura de Mani e sua heresia: "Mani, o babilônio, era um cristão de religião, mas mazdeano de formação. É ele que dá origem aos dualistas, que professam dois deuses - um é o deus criador do bem, a luz, outro o deus criador do mal, a treva. A heresia consiste em transpor o verdadeiro (al-tajawus), alterando a significação, a causa dessa transposição fora da unidade essencial e operando essa transposição na falsa dualidade.” (Id., parágrafo 36, p. 247). 
associar outros deuses com o único Deus ${ }^{57}$ - seja Ele exaltado por sobre todos os antropomorfismos. ${ }^{58}$

Para Suhrawardī, a sabedoria é uma experiência presencial e cognoscitiva que existe desde sempre; o mundo, como ele bem o lembra,

nunca esteve sem sabedoria ou sem uma pessoa que possuísse as provas e evidências clara para defende-la. Essa pessoa é o vice-regente (halifa) de Deus na terra. Sempre será assim, enquanto durarem os céus e a terra.

Não há diferença entre sábios antigos e modernos, senão no vocabulário e no uso da língua, seja ao expor diretamente o seu pensamento (tașrīh), seja ao apresentar sob o véu de alusões simbólicas. Todos afirmaram a realidade de três mundos. Todos são unânimes na afirmação da unicidade (tawhīd); não havendo nenhuma disputa entre eles no que é fundamental. Bem que o primeiro mestre [Aristóteles] haja sido um homem de grande valor e de autoridade eminente entre os sábios, de espírito profundo e de um rigor especulativo perfeito, é, no entanto, inadmissível se exagerar sobre ele [Aristóteles], de uma maneira que menosprezasse os que foram seus mestres e dos quais tudo aprendeu. Entre os seus mestres estão os mensageiros e legisladores, como Agatodeimon, Hermes, Asclépio e outros". 59

Mais adiante, ao explicar que o criador de todas as coisas é luz e que os símiles estão entre as luzes dominantes, Suhrawardī repete que

a maioria das alusões dos profetas e dos pilares da sabedoria se referem a isso. Platão e aqueles que o precederam, como Sócrates, seus predecessores como Agatodeimon e Empédocles, todos sustentam esse ponto de vista. A maioria dos sábios disse que contemplaram [a luz] no mundo de pura luz. O próprio Platão afirmou que se despojou da obscuridade e contemplou a luz. Os sábios da Pérsia e da Índia, sem exceção, estiveram de acordo sobre isso. Se as observações de uma ou duas pessoas são suficientes e pensam no estudo dos

\footnotetext{
${ }^{57}$ Quțb al-Dīn explica que os magos ímpios são os que professam o aspecto oculto da luz e das trevas e afirmam que se tratam de dois princípios primordiais. Os magos se corromperam, antes do islã, e se tornaram os "associadores" (mušrikūn) e não professam mais a unidade (muwahhhidūn). (Id., p. 246, parágrafo 246).

${ }_{58}^{58}$ SUHRAWARDĪ, op. cit., parágrafo 4 (Corbin, pp.89-90 ; Walbridge \& Ziai, p. 2).

${ }^{59}$ Ibid., par. 4 (Corbin, pp.89-90 ; Walbridge \& Ziai, pp.2-3 ).
} 
astros, como, então, podemos ignorar o testemunho dos pilares da sabedoria e profecia a partir de suas observações espirituais?

$\mathrm{O}$ autor dessas linhas era entusiasmado em defender a escola peripatética na negação dessas realidades, mesmo que por elas já tivesse forte inclinação. E teria perseverado na via peripatética se não houvesse visto a "demonstração de seu Senhor (burḥan rabi-hi)" (Alcorão XII, 24). Se há alguém que não dá crédito a essa demonstração, e a quem isso não é suficiente, que se empreenda ao seu redor em exercícios espirituais (riyā mestres em contemplação (aṣhab al-mošāhada). Talvez, então, chegue à visão da luz que infunde no mundo do Jabarūt, e verá os anjos do Malakūt e as luzes que contemplaram Hermes e Platão, os clarões celestes, princípios da luz de glória. É delas que nos informa Zoroastro. É em direção delas que um êxtase arrebata o soberano verídico, o bem-aventurado Kay Hosraw, que obteve a visão-direta. Os sábios da Pérsia são unânimes sobre este ponto, se bem que segundo eles, a água tem um anjo [um "senhor do ícone"] no Malakūt; eles o chamaram de "Hordād". Há o das plantas, chamado por eles de "Mordād"; e o do fogo, ao qual eles chamavam de "Urdibihišst".E são estas mesmas as luzes que Empédocles fizera alusão e vários outros além dele. ${ }^{60}$

Para Suhrawardī o conhecimento verdadeiro é aquele obtido pelo sábio que possui a sabedoria discursiva e a experiência contemplativa. Por isso, a genealogia que o autor atribui à sua filosofia é significativa, uma vez que autentica uma sabedoria universal evidenciada e transmitida pelos mais diversos sábios procedentes de diferentes geografias, que conseguiram expressar sua verdade por meio de símbolos irrefutáveis.

Nada nos indica que Suhrawardī se interessara em sistematizar esse canal de conhecimento, senão revelar que a sabedoria de Platão, de Hermes, de Pitágoras, de Zaratuštra, dos sábios persas por ele mencionados, está fundamentada em uma mesma experiência iluminativa e presencial. Assim, as diversas alusões aos "antigos" recobrem atualidade e importância e são suficientes para indicar onde se deve olhar e buscar para reconstruir essa cadeia filosófica. A sabedoria, tal qual compreendeu Suhrawardī, é manifestação. Como os sábios antigos expressaram essa verdade revelada por meio de símbolos, essa sabedoria se transmitiu de mestre a discípulo e de

${ }^{60}$ Ibid., par.165-166 (Corbin, pp150-151 ; Walbridge \& Ziai, pp.107-108). 
geração a geração. Na genealogia apresentada por Suhrawardī estão alguns exemplos disso e, apesar da diferença de método e de contexto, é no Livro da sabedoria da iluminação que toda essa tradição converge. Assim, a sabedoria deve, para Suhrawardī, ser reanimada por aqueles capazes de repetir a experiência iluminativa de seus fundadores. A sabedoria foi revelada ao homem por meio de Hermes, "o primeiro dos sábios", e por meio dele para os sábios da Caldeia, da Pérsia e do Egito. Do Egito se transmitiu à Grécia e, pelos gregos, para a civilização árabe. Com efeito, Suhrawardī não considerou como seus predecessores imediatos outros falāsifa, mas os mestres sufis ${ }^{61}$. Se se quer reconstruir essa cadeia filosófica geograficamente, se terão várias linhas que convergem, todas, em Suhrawardī:

- Egípcia: Hermes, Agatodeimon, Asclépio.

- Grega: Pitágoras, Empédocles, Sócrates, Platão, Aristóteles.

- Caldeia e persa: Gajomart, Zarațuštra (Zoroastro), Jāmāsp, Frašaoštra, Bozorġmer, Faridun, Kay Hosraw.

- Islâmica: al-Misrī, al-Tustāri, al-Bistāmi e al-Jarraqāni.

- Oriental: Budasf ${ }^{62}$ (Buda).

Assim, Suhrawardī entendeu que um novo modo de se fazer filosofia consiste em recuperar os velhos mestres. Sua obra toda pode ser interpretada como uma crítica aos peripatéticos, mostrando a insuficiência em se colocar a lógica aristotélica como fundamento da metafísica. Para tanto se reporta a Platão e a Hermes. Eles são os pais do verdadeiro saber. Ao estabelecer a genealogia do verdadeiro conhecimento, Suhrawardī percebe o quanto esse mesmo conteúdo estava presente em Zaratuštra ${ }^{63}$ e

61 A menção aos mestres sufis aparece explicitamente no diálogo que mantém com Aristóteles (V. FAKRY, M. op. cit., p.320).

${ }^{62}$ Quṭb al-Dīn apresenta Budasf como o primeiro entre os sábios do Oriente, precisando a seguir, o que é o Oriente, isto é, a Índia e a China. Sua doutrina não difere da dos sábios da Grécia, do Egito, da Pérsia e da Caldeia, mas de pouca influência em Suhrawardī. Budasf seria citado na obra de Suhrawardī, por haver sido o mais eminente defensor da doutrina da transmigração das almas. ("Deuziême partie : Commentaires de Qotboddîn Shîrâzî", Livre de la sagesse orientale, commentaires de Quoṭboddin SHÎRÂZÎ e Mollâ ȘADRÂ, tradução e notas por Henry Corbin, edição e introdução por Christian Jambet. Paris: Verdier, 1986, p.392, parágrafo 1)

${ }^{63}$ Essa síntese foi executada, três séculos mais tarde, pelo filósofo bizantino Gemiste Pleton (m. entre 1450 e 1464 d.C.). Portador de grande erudição filosófica, Pleton via na síntese entre Platão e Zoroastro a única forma da filosofia grega sobreviver. Temia sobremaneira o aristotelismo dos latinos e a filosofia dos muçulmanos, pois via nelas ameaças ao mundo grego, ameaçado política e militarmente, também, pelos latinos e pelos turcos (muçulmanos). O testemunho de Genado Scholarios (em sua carta ao exarca José, Migne, P.G. 160, p.639, citado in BIDEZ e CUMONT, Les mages hellénisés, II, fr.0116, p.261ss., 
na tradição persa. Não se trata aqui de se postular uma volta à Pérsia pré-islâmica, mas de se estabelecer uma ligação profunda entre os sábios gregos (Platão, Empédocles, Pitágoras, Aristóteles, entre outros), caldeus e persas (Jāmāsp, Frašostar, Borzorġmer e Zaratuštra, entre outros), egípcios (onde se destaca Hermes, o imam do conhecimento, Agatodaimon, um dos mestres de Aristóteles, Asclépios, o primeiro entre os médicos) e sufis (al-Bistāmi e al-Hallāj) ${ }^{64}$. Assim sendo, percebe-se que não faz sentido especular sobre o projeto de restauração cultural persa de Suhrawardī. Sobre algum contato de Suhrawardī com as resistências persas, parece razoável sustentar que mais do que procurar reviver a religião e a sabedoria da antiga Pérsia, Suhraward̄̄, a partir da Pérsia e de outras tradições sapienciais, procura encontrar na antiga sabedoria elementos que ratifiquem sua nova cosmovisão. Não é de se estranhar que Suhrawardī procure, a todo o momento, estabelecer a unidade entre os sábios persas, caldeus, gregos e árabes. Suhrawardī acredita que a revolução por ele perpetrada não é descoberta sua, mas já fora feita, através de seus métodos de meditação e de suas pregações, por alguns sufis, em particular, al-Bistāmi e al-Hallāj. Contudo, esses não

e a carta à princesa do Peloponeso, Oeuvres completes de Gennade Scholarios, ed. L. Petit, SIDERITÈS e JUGIE, Paris, 1935, citado in BIDEZ e CUMONT, II, fr.0115, p.260), afirma que Pleton conheceu e aprendeu a venerar, em sua passagem pela corte do sultão turco seldjúcida, o pensador Eliseu, o judeu, personagem influente, grande conhecedor de Ibn Rušd e de outros comentadores árabes de Aristóteles. Entretanto, segundo Genado, Eliseu era judeu apenas aparentemente, sendo pagão e politeísta. Tratarse-ia de uma controvérsia para desacreditar Pleton? Possivelmente, mas nada o leva a afirmar seguramente. Talvez haja sido acusado de "pagão" e "politeísta" por se tratar de um judeu conhecedor e discípulo de Ibn Rušd. Este era o filósofo árabe mais conhecido pelos latinos, e por esse título, era conhecido em Constantinopla. Sabe-se que havia muitas traduções de Ibn Rušd em hebraico - Genado fala também de versões hebraicas de Aristóteles que Pleton haveria conhecido. Além disso, segundo Genado, Eliseu falava de Zoroastro sem ser zoroastrista e parece ser pouco provável que um judeu houvesse, na corte turca, abraçado o politeísmo ou o zoroastrismo. Isso levou Shlomo Pinès a lançar a seguinte hipótese: será que Eliseu adotou a doutrina de Suhrawardī? Sabe-se que no século XIII d.C., outro judeu, Ibn Manșūr Ibn Kamūna foi um importante comentador das obras de Suhrawardī. O contato com essa poderosa corrente de ideias - a de Suhrawardī - haveria marcado Pleton? Com efeito, o platonismo de Pleton pode ser explicado apenas com recurso às fontes gregas, sem necessidade de apelar para uma dependência išr $\bar{q} q \bar{l}$. Mas parece ser razoável não descartar que o conhecimento da tradição iluminacionista pode ter posto Pleton na mesma tradição. F. Taeshner tratou (Islam, 1929, p.236) sobre as influências sobre Pleton de sua passagem entre os turcos. Taeshner, por sua vez, não menciona nada sobre Suhrawardī. A questão que se impõe para constatar a razoabilidade dessa hipótese é: o sistema iluminacionista era conhecido no império otomano no século XV? Se sim, em que medida? (PINÈS, Scholomo. «La "Philosophie Orientale" d'Avicenne et sa polemique contre les bagadiens » in The collected works of Schlomo PINĖS, Volume III : Studies in the History of Arabic Philosophy. Jerusalém: The Magnes Press \& The Hebrew University, 1996, pp. 301-333 [pp.1-37], pp.330-331 [p.34-35], nota 2). Paul Fenton, em Deux traités de mystique juive (Paris: Verdier, 1987, 334 pp.), aponta como iluminacionista o rabino egípcio Dāwūd Ibn Maymūn, descendente do grande Mūsā Ibn Maymūn (Maimônides), liderança da comunidade judaica do Cairo no século XIV d.C.. Haveria contribuído os judeus na circulação do pensamento de Suhrawardī, de forma mais ou menos análoga ao que contribuíram com Ibn Rušd? Uma questão para se pesquisar. Ver nota 317.

${ }^{64}$ FAKRY, M. op. cit., p. 320 . 
souberam ou não foram capazes, por não dominarem o saber discursivo, de transmiti$1 a^{65}$.

Como se pode ver, para Suhrawardī, Platão é o "guia e mestre"; Hermes é “o primeiro dos sábios" e também o "pai dos pais ('ab al-'ābā')", Empédocles e Pitágoras "os pilares"; os sábios persas, assim como Agatodaimon e Asclépios, são, junto com Hermes, "mensageiros e legisladores" e, por fim, os "grandes sábios" Platão e Aristóteles. Assim, Hermes é apresentado como o antecedente comum das tradições sapienciais persas, egípcias e gregas, que convergem no sistema desenvolvido por Platão. Zoroastro e a tradição dos reis e sábios persas confirmam igualmente a doutrina platônica e a relação complementar entre luz e obscuridade. Todos os sábios gregos, Pitágoras, Empédocles e Aristóteles estavam de acordo com Platão. Curiosamente não há no Livro da sabedoria da iluminação menção a filósofos judeus, cristãos e de outros muçulmanos, a não ser menções indiretas a Ibn Sīnā.

Pode-se concluir que Suhrawardī em seu Livro da sabedoria da iluminação busca dois objetivos fundamentais: reformular a tradição peripatética, predominante entre os filósofos árabes de sua época e, ao mesmo tempo, recuperar a filosofia anterior a Aristóteles, através das mais diversas tradições sapienciais que confirmam sua cosmovisão por inteiro. Precisamente, o título de sua obra, Livro da sabedoria da iluminação, é chave para se perceber que nela se combinam justamente a tradição dos antigos e o método iluminacionista sobre o qual se fundamenta sua ciência das luzes.

\section{Apresentação do Livro da sabedoria da iluminação: o conhecimento} pelas luzes

Pelo que vimos a respeito da vida e da obra de Suhrawardī, pode-se afirmar que o Livro da sabedoria da iluminação é o núcleo do seu pensamento. Aí se encontra todo o seu sistema. Nesse sentido, essa obra tem por função ampliar e especificar cada um dos aspectos didáticos que ofereceu em seus relatos simbólicos, em que sua doutrina sobre a realidade está exposta explicitamente em termos de experiências vivas e individuais - sempre ricas em símbolos e poesia.

${ }^{65}$ Ibid., p.320. 
Em seu prólogo ao Livro da sabedoria da iluminação, Suhrawardī se refere ao propósito, à natureza e para quem se destina esse novo livro.

Eis, pois, ó meus irmãos: sabeis que vossa repetida insistência em obter por escrito a sabedoria da iluminação fez dobrar o meu firme propósito em me abster; ela fez cessar minha tendência em não vos ajudar. Se não houvesse uma necessidade imperativa, uma palavra (kalima) que ultrapassa a mim mesmo, um imperativo (amr) tal sobrevindo do alto lugar, que transgredi-lo equivaleria a sair da via divina, pois bem, eu não teria razões suficientes para o empreendimento de publicar semelhante livro, uma vez que sabeis as dificuldades que isso comporta. Contudo, ó grupo fiel de meus companheiros, - que Deus nos ajude naquilo que Ele ama e que Ele aprova! - não haveis cessado de exigir que eu escrevesse para vós um livro no qual rememoro as experiências que me vieram por meio da percepção-contemplativa ( dawq ao curso de meus retiros e de minhas etapas [sobre a via contemplativa].

Certamente, em toda alma que busca [a sabedoria] acontece uma parte da luz de Deus, seja fraca ou abundante, e para todo buscador completo há certa percepção-contemplativa $(\underline{d} a w q)$, ela sendo deficiente ou perfeita. [...]

Anteriormente ao presente livro, e mesmo enquanto eu estava ocupado em compô-lo, em meio aos obstáculos que vinham sem cessar, eu já escrevi para vós certo número de livros segundo o método dos peripatéticos (al-mašša'ūn). Examinei, nesses livros, os fundamentos de sua filosofia. Nomearei, entre outros, meu compêndio intitulado as Elucidações inspiradas da Tábua e do Trono (al-talwīhāt al-lawhīya wa'l-'aršìya) ${ }^{66}$. Esse livro, apesar de seu pequeno volume, inclui um grandioso número de teses, minha exposição reconduz à sua quintessência. Nomearei ainda meus Resumos (Kitāb allamahāt - Livro dos resumos em clareza). Fora esses dois livros, compus outros, especialmente os que, no tempo de minha juventude, escrevi.

Quanto ao livro presente, este apresenta uma ordenação (siyāq) diferente e um método mais direto que o dos peripatéticos, uma via melhor ordenada e melhor regulada, necessitando menos do esforço para a obtenção do resultado. Isso, pois, não adquiri, em primeiro lugar, por meio de uma sabedoria

${ }^{66}$ Cf. SUHRAWARDĪ, Op. I, p. 1-121. 
discursiva. Não, não é por meio [da sabedoria discursiva] que consegui, em primeiro lugar, o resultado, e é somente mais tarde que procurei instaurar a prova [discursiva], não havendo nada no mundo que possa me fazer duvidar do que coloquei nesse livro ${ }^{67}$.

Percebe-se que, em primeiro lugar, Suhrawardī explica como concebeu esse livro, fazendo referência a um grupo de amigos que lhe pediram mais explicações sobre seu ensinamento filosófico. Em segundo lugar, Suhrawardī afirma que, se bem que escreveu outros livros, este é o produto de sua experiência pessoal, de sua percepção contemplativa, para o qual buscou provas. Por isso, afirma que esta referida obra tem outro método, mais sistemático e mais acessível aos estudantes, e confirmado pela experiência dos antigos:

Para tudo isso que tratarei concernente à ciência das luzes ( ${ }^{c} i l$ al-anwār), como para tudo isso que é fundado sobre tal conhecimento, assim como pelo resto, ajudam-me todos esses que caminham sobre o caminho de Deus. Esse conhecimento foi, pois, a experiência íntima de Platão, o guia e o chefe do início da sabedoria (imām al-ḥikma wa ra'īsuḥa), homem dotado de força e de uma grande luz interior. Assim o foi em tempos mais antigos Hermes, o pai dos sábios contemplativos, até a época do próprio Platão e de outros sábios eminentes, pilares da sabedoria, tais como Empédocles, Pitágoras e outros ainda. Ora, a doutrina desses antigos sábios se apresenta sob a forma de símbolos. Também não há nenhuma refutação contra esses [símbolos]. Mesmo que se pretenda argumentar contra a aparência exotérica de suas doutrinas, jamais se encontrará assim suas intenções verdadeiras, pois não se refutam os símbolos. Ora, é precisamente sobre o símbolo que está fundado a doutrina iluminacionista ( $q \bar{a}^{c} i d a t$ al-išr $\bar{a} q$ ) concernente à luz e às trevas, doutrina que constituiu o ensinamento próprio aos sábios da antiga Pérsia, tais como Jāmasp, Frašaoštra, Bozorġmer e outros ainda antes deles ${ }^{68}$.

Posteriormente Suhrawardī diferencia explicitamente os graus de conhecimento em várias categorias, confirmando assim a quem se dirige:

\footnotetext{
${ }^{67}$ SUHRAWARDĪ, Kitāb hikmāt al-išr $r a ̄ q$, par. 2 e 3 (Corbin, pp.85-88; Walbridge \& Ziai, pp.1-2).

${ }^{68}$ Ibid., par.4 (Corbin, pp. 88-90; Walbridge \& Ziai, pp. 2-3).
} 
Há vários graus [da sabedoria]; eles formam uma hierarquia (tabaqāt), e se repartem da seguinte maneira:

há o sábio divino (hakìm ilāh $\vec{\imath}$ ) perfeitamente proficiente em sabedoria intuitiva $^{69}$ ( ta $^{\prime}$ alluh), mas que é desprovido da sabedoria discursiva (baht);

há o sábio (hakim), perfeitamente proficiente em sabedoria discursiva, mas desprovido da sabedoria intuitiva;

há o sábio divino que penetrou fortemente e ao mesmo tempo na sabedoria intuitiva e na sabedoria discursiva;

há o sábio divino que penetrou profundamente na sabedoria intuitiva, mas mediana ou fracamente na sabedoria discursiva;

há o sábio divino que penetrou profundamente na sabedoria discursiva, mas mediana ou fracamente na sabedoria intuitiva;

há o buscador que procura ao mesmo tempo a sabedoria intuitiva e a sabedoria discursiva;

há o buscador que procura apenas a sabedoria intuitiva;

há o buscador que procura apenas a sabedoria discursiva ${ }^{70}$.

Para Suhrawardī, os sábios são aqueles que possuem simultaneamente a filosofia intuitiva e a filosofia discursiva. Uma vez estabelecida as diferenças nos graus de conhecimento, o autor afirma que este livro é destinado

precisamente a esses que aspiram ao mesmo tempo à sabedoria intuitiva e à sabedoria discursiva. Nem o sábio dialético, estranho à sabedoria intuitiva, nem o buscador que não tem a sabedoria intuitiva, encontrarão nesse livro algo que se enderece a eles. É por isso que nesse presente livro e nos símbolos (rumūz) que ele contém não praticaremos a sabedoria discursiva; nossas discussões se endereçam apenas ao contemplativo perfeito (mujtahid), mas podem ser lidas pelos que tem proeficência na sabedoria intuitiva ou, ao menos, que procuram e aspiram pela sabedoria intuitiva. O grau mínimo

\footnotetext{
${ }^{69}$ Método filosófico baseado na apreensão direta dos inteligíveis, ao contrário da sabedoria discursiva (método filosófico baseado apenas na razão e que segue os ditames da lógica aristotélica).

${ }^{70}$ Ibid., par.5 (Corbin, p. 90; Walbridge \& Ziai, p.3).
} 
requerido ao leitor do presente livro é que já lhe haja vindo bruscamente o relâmpago da iluminação divina (bāriq ilāhlu) e que a erupção haja lhe passado ao estado de hábito (malaka) ${ }^{71}$.

Essa obra, portanto, foi escrita para aqueles que saborearam a verdadeira sabedoria. $\mathrm{O}$ mesmo se refere ao seu método - o iluminacionista (išrāq $\bar{l})$ - em contraste com os peripatéticos (mašš $\bar{a}$ 'un), método corrente entre os filósofos árabes em muitas de suas obras.

O objetivo do Livro da sabedoria da iluminação é apresentar um novo método de filosofia e de ciências, mais sólido: a ciência das luzes ( ${ }^{c} i l m$ al-anwār). Para tanto, Suhrawardī construiu uma teoria epistemológica baseada no conhecimento pela presença ( ${ }^{c} \bar{l} l m$ ḥudūrī). Sua metafísica se constrói, assim, a partir das ambiguidades e contradições que constatou no Aristóteles conhecido em língua árabe. Em outras palavras, para a construção de uma nova metafísica foi necessária a construção de uma teoria do conhecimento intuitivo de maneira científica. Pode-se, desse modo, afirmar que uma das principais originalidades de seu pensamento é o fato de haver identificado o seu projeto epistemológico-metafísico com as mais diferentes tradições e escolas pré-aristotélicas. Consequentemente, a novidade trazida por Suhrawardī residiu em sua crítica ao valor universal dado à metodologia científica aristotélica, que elaborou em comunhão com as tradições antigas, pré-aristotélicas, advogando, assim, um "neo-neoplatonismo", procurando estabelecer, nessas bases, uma teoria do conhecimento mais coerente e unificada.

\footnotetext{
${ }^{71}$ Ibid., par.6. (Corbin, p. 92; Walbridge \& Ziai, p.4).
} 


\section{CAPÍtulo II}

\section{A LÓGICA DE SUHRAWARDĪ E A DESCONSTRUÇÃo DA LÓGICA ARISTOTÉLICA}

\section{1) O Livro da sabedoria da iluminação: estrutura, método e conteúdo}

O Livro da sabedoria da iluminação é dividido em duas partes. A primeira, formada de três livros menores, expõe a lógica dos peripatéticos e procura mostrar o quanto a mesma é insuficiente para explicar a realidade. É a parte lógica, estruturada em três tratados. A segunda trata da ciência das luzes, estruturada em cinco tratados. Eis a forma como Suhrawardī dividiu sua obra:

Primeira parte: As regras do pensamento

1. Conhecimento e definições (sete regras);

2. Sobre as provas e seus princípios (sete regras);

3. Sobre as refutações sofísticas e alguns juízos entre os iluminacionistas e a doutrina peripatética (em várias seções).

Segunda parte: Sobre as luzes divinas, a luz das luzes, as bases e a ordem da existência.

1. Sobre a luz e sua realidade, a luz das luzes e o que primeiro dela se gerou (nove seções e regras);

2. Sobre a ordem da existência (em catorze seções);

3. Explicação sobre a atividade da luz das luzes, as luzes dominantes e um desenvolvimento da discussão sobre os movimentos celestes (em catorze seções);

4. Sobre a classificação dos limítrofes, seus estados, suas combinações e alguns dos seus poderes (em oito seções);

5. Sobre a ressurreição dos mortos, a profecia e os sonhos (em nove seções).

Depois de apresentar em seu prólogo o projeto do Livro da sabedoria da iluminação, reconstruindo os fundamentos da filosofia sobre um terreno no qual a sabedoria é guiada e confirmada pelo pensamento racional, Suhrawardī dedica essa 
primeira parte a um estudo analítico e cuidadoso da lógica segundo fora formulada por Aristóteles e, posteriormente, por Porfírio, ambos conhecidos pelos pensadores árabes.

Essa é a seção mais breve do livro,

[...] a famosa ferramenta (Organon) que garante o exercício do pensamento discursivo, nós a daremos no início desse livro, por um resumo que contém regras pouco numerosas, mas de um proveito considerável. Elas serão suficientes para todo aquele que é dotado de um espírito penetrante, assim como aquele que aspira à iluminação (išrāq). Que aquele que, assim, está em busca do detalhe concernente à ciência que constitui o Organon se reporte às obras especializadas $^{72}$.

Nessa parte do livro Suhrawardī apresenta um compêndio essencial de procedimentos que se convertem em uma lista analítica e descritiva de suas principais críticas à filosofia peripatética e, consequentemente, à filosofia até então corrente entre os pensadores árabes. Estabelece-se aí um esquema em que a lógica aristotélica utilizada até então se viu formalmente confrontada. A partir desse ponto, percebe-se como Suhrawardī conseguiu construir e sustentar sua ciência das luzes ( ${ }^{c} \bar{l} l m$ al-anwār $)$.

É sobre essa desconstrução epistemológica de pontos importantes na lógica peripatética que trataremos aqui. Procuraremos fazê-lo, observando esse processo operado em cada tratado.

\section{2) O Tratado I. A Definição}

Nesse primeiro tratado sobre semântica, no que se refere à definição, Suhrawardī estabelece sete regras: sobre a forma como uma palavra pode significar o significado (1); sobre a divisão entre a concepção e o assentimento (2); sobre as quididades (3); sobre a diferença entre acidentes essenciais e acidentes separáveis (4); a afirmação de que o universal não existe fora do intelecto (5); sobre o conhecimento humano (6); e, sobre a definição propriamente dita e suas condições (7).

Ao estabelecer a regra segundo a qual se pode entender o significado de uma palavra, Suhrawardī afirma que isso só acontece quando se pode, a partir do mesmo

\footnotetext{
${ }^{72}$ Ibid., par. 6. (Corbin, pp. 92-93; Walbridge \& Ziai, p.4).
} 
conceito, captar outros diversos sentidos ${ }^{73}$. O significado pode ser natural, como em uma onomatopéia, ou apresentar uma significação artificial, referente à consequência de uma afirmação, se tratando de uma significação implícita. O significado diretamente pretendido de uma palavra é sempre acompanhado paralelamente - e de forma indireta, "parasitária"74 -, chamando-se sempre de significação concomitante. No entanto, isso não ocorre quando a palavra quer expressar algo simples e insdivisível, pois entre os existentes não há concomitantes e a palavra quer expressar apenas algo simples e indivisível no seu significado ${ }^{75}$. O universal, conclui Suhrawardī, enquanto conceito, não quer significar o específico em sua especificidade. A seguir, Suhrawardī afirma que o conhecimento de alguma coisa, qualquer que seja, exige uma presença da coisa conhecida no sujeito que a conhece. No conhecimento há, assim, uma imagem e uma maneira de identificação entre a imagem e o sujeito cognoscente. Suhrawardī não se refere ainda a uma imediata ciência presencial, dentro da qual o que apreende se une diretamente ao que é apreendido.

No que se refere às quididades, cada espécie de ser ou é simples - sem partes no intelecto - ou é não-simples - com partes no intelecto ${ }^{76}$. Cada uma dessas características é inseparável de seus acidentes. As espécies não-simples são apreendidas interiormente e ligadas à descrição da essência e não se referem simplesmente a uma produção constante. O significado específico para a coisa pode ser igual à própria coisa (tal como a capacidade do homem de se expressar por palavras). A realidade pode ter "acidentes separáveis da quididade", tais como o riso real do homem, ou pode ter "acidentes concomitantes à quididade". O completo concomitante é, segundo Suhrawardī, o concomitante relacionado essencialmente com a realidade - por exemplo, a relação dos três ângulos com o triângulo. Mesmo na imaginação, é impossível se imaginar um triângulo sem três ângulos. Suhrawardī, a

\footnotetext{
${ }^{73}$ Suhrawardī, op. cit., par. 7 (Walbridge \& Ziai, p.5).

${ }^{74}$ HORTEN, Max. „Die Philosophie der Erleuchtung nach Suhrawardī $\left(1191^{+}\right)^{“}$. Halle A.S.: Niemeyer, 1912, pp. I-XI; pp. 1-83, p. 5 [Islamic Philosophy (volume 90): Shihābaddīn Yahyā Ibn Habash AsSuhrawardī (d. 587/1191): Texts and Studies (I). Collected and reprinted by Faust Sezgin in collaboration with Mazen Amawi, Carl Ehrig-Eggert, Eckhard Neubauer. Frankfurt am Main: Institute for the History of Arabic-Islamic Science at the Johan Wolfang Goethe University, 2000, pp. 35-123, p. 47].

${ }^{75}$ Suhrawardī, op. cit., par. 7 (Walbridge \& Ziai, p.5).

${ }^{76}$ Ibid., par. 9 (Walbridge \& Ziai, p.6).
} 
seguir $^{77}$, estabelece que caso se queira distinguir entre a realidade propriamente dita e vista em sua essência e o que se segue da realidade através de uma causa eficiente, se deve contemplar a realidade como uma coisa única. Os atributos se formam de sua essência e dela, consequentemente, se diferenciam na sua finalidade. Esses atributos se diferenciam dos que são marcados por causas exteriores e isso não forma o conteúdo da ciência. Assim, o pensamento do acidente, concomitante ou específico, é posterior ao pensamento da realidade, e a realidade desempenha um papel na realização de sua existência. $\mathrm{O}$ acidente pode ser mais geral que a coisa (como a capacidade do homem de caminhar) ou pode ser específico à coisa (como a capacidade do homem de rir). Com efeito, prossegue Suhrawardī, o que é universal não contém nenhuma realidade fora do intelecto ${ }^{78}$, a não ser em contato com a especificidade do sujeito cognoscente. Se o sentido universal também se aplica a muitos, como "quatro", para as suas instâncias, é chamado de um "contínuo universal". Se se pode aplicar à coisa mais ou menos completamente, como se aplica o branco à neve, ao marfim e a outras coisas em que o branco se faz mais ou menos presente, então a cor branca é chamada de "significado diferente". Quando muitos nomes são ditos de uma mesma coisa, cada um deles é chamado de "sinônimo". Quando várias coisas são chamadas por um nome e não são usadas com um significado único, chamam-se seus exemplos de "equívoco". Se um nome for usado com outros de seu significado, devido a alguma semelhança, proximidade ou concomitância, se chama isso de "metafórico".

Suhrawardī observa que o conhecimento humano pode ser inato ou obtido e transferido por outras vias que não são inatas ${ }^{79}$. Mesmo Suhrawardī reconhecendo que nem todo o conhecimento é inato, se deve, no entanto, afirmar que o conhecimento primeiro, aquele que funda todas as demais maneiras de se conhecer, é inato. Utilizando a expressão peripatética "a evidência tem diversos graus", deve-se postular um grau primeiro, pois o conhecimento não é compatível com infinitas pré-condições, se não, não poderia ser formado como tal ${ }^{80}$.

\footnotetext{
${ }^{77}$ Ibid., par. 10 (Walbridge \& Ziai, p.7).

${ }^{78}$ Ibid., par. 11 (Walbridge \& Ziai, p.7).

${ }^{79}$ Ibid., par. 12 (Walbridge \& Ziai, p.8).

${ }^{80}$ Ibid., par. 12 (Walbridge \& Ziai, p.8).
} 
A definição, tal como sustentam os peripatéticos, se dirige aos que não conhecem a coisa tal como ela é. Com efeito, Suhrawardī sustenta que a definição não pode se formar de uma maneira só ${ }^{81}$; a definição deve ser apresentada por algo mais aparente do que a coisa definida, não por alguma coisa mais obscura do que aquilo que se quer definir ou por algo que só é sabido por meio da coisa a ser definida. Assim, para Suhrawardī, não é correto definir, por exemplo, o "pai" como "o que possui um filho", porque "pai" e "filho" são igualmente conhecidos ou desconhecidos: quem sabe um, conhece também o outro, e quem desconhece um, o outro desconhece. Ademais, uma condição para que uma coisa seja definida é que ela seja conhecida antes de outra coisa que se quer definir e não simultaneamente a ela. É incorreto dizer que "o fogo é um elemento que se assemelha à alma", porque a alma é algo mais obscuro que o fogo. Da mesma maneira, é incorreto dizer que "o Sol é um corpo celeste que se eleva a cada dia”, porque o dia só é conhecido pelo período de tempo marcado pelo Sol elevado. A definição da realidade não pode ser apenas uma substituição de uma palavra em uma sentença, pois essa substituição só é útil a alguém que conhece a realidade, mas torna incerto o significado da palavra. Assim, as definições dos relativos devem mencionar o fundamento que estabelece a relação; do mesmo modo, a definição de derivados deve mencionar que a partir do quê a derivação é feita em conjunto com outra coisa, dependendo dos locais de derivação.

Alguém usa o termo "definição" para uma fórmula que indica a quididade da coisa $^{82}$. Essa fórmula indica o essencial e os aspectos internos à realidade da coisa. A fórmula que faz com que a realidade seja conhecida pelo que é exterior é chamada de "descrição". ${ }^{83}$

A definição conceitual através de acidentes ${ }^{84}$ é uma descrição. A maioria dos homens percebe apenas o sensorial. Um exemplo disso, apresenta Suhrawardī, está na definição do corpo: para uns o corpo se constitui como tal a partir da matéria e da

\footnotetext{
${ }^{81}$ Max HORTEN, op. cit., p. 7 [p. 49].

${ }^{82}$ Ibn Sīnā em seu Livro das diretivas e notas (Kitāa al-'išărāt wa l-tanbīhāt) [Livre des Directives et Remarques: "A definição é enunciado indicando a quididade da coisa". Nos Tópicos (I, 5 ap, 101 b 38), Ibn Sīnā apresenta a definição "como um discurso, não com uma palavra só, que expressa o conhecimento de uma quididade" (introduction, traduction et notes par A.-M. Goichon. Beirute-Paris: Comission Internationale pour la traduction des chefs d'ouvre et Librarie philosophique J. Vrin, 1951, 552 p., pp. 103-104, notas 3 e 1).

${ }^{83}$ Suhrawardī, op. cit., par. 14. (Walbridge \& Ziai, p. 9).

${ }^{84}$ Ibid., par. 12 (Walbridge \& Ziai, p.8).
} 
forma, para outros, o corpo é um complexo único, sem partes, e para terceiros, é admitido como sendo um complexo de átomos ${ }^{85}$. No entanto, para quase todos os que admitem que o corpo seja composto de átomos, estes não estariam na definição de corpo $^{86}$.

Dessa maneira, Suhrawardī rechaça o conceito aristotélico de definição, pois os peripatéticos utilizam "o termo definição (hadd) como fórmula para indicar a essência ( $\underline{d} \bar{a} t)$ de alguma coisa" ${ }^{\$ 7}$. Ora, esse conhecimento supõe o conhecimento da essência de uma determinada realidade, através do qual se estipula que o desconhecido só pode ser obtido por meio do conhecido:

os peripatéticos admitem que o essencial específico e geral de uma coisa devem ser mencionadas em sua definição. Gênero (jins) é o nome para seu essencial geral que não é parte de outra essencial geral pertencente à verdade universal (al ḥāqiqa al-kulīyya) explicada pela resposta à pergunta "o que é isto?” Eles chamam a o específico essencial de uma coisa, a diferença $(f a s ̣ l)^{88}$.

A definição é uma resposta através da qual se procura definir e redefinir algo até que se possa conhecer desse algo o que realmente é. Com efeito, trata-se de uma limitação. Trata-se da indicação dos fins ou limites conceituais de um existente com respeito aos demais que se conceberam com frequência como uma negação a respeito de outra coisa até se ficar com a coisa definida (A é A e não B). Exatamente por isso, esse processo não é o mesmo que distinguir. Diferencia-se que A é A e não é $\mathrm{B}$, mas define-se no que consiste A, isto é, que coisa é, qual é sua essência. A definição é, assim, um processo intelectual pelo qual através de um termo médio é permitido saber o que é um existente dado, ou seja, a sua quididade ${ }^{89}$. Diferentemente de sua

\footnotetext{
${ }^{85}$ Apreende-se o gênero sine conditione derterminationis, um verdadeiro gênero, se apreende $s u b$ conditione determinationis, da matéria e se apreende sub conditione determinationis através de diferenças específicas, nas espécies. Referente ao corpo, o problema se põe da seguinte maneira: existe em suas duas partes (gênero e diferença), através de uma existência - ensinamento dos acadêmicos (arruwakijûn) - ou através de duas - como ensinado pelos peripatéticos (HORTEN, Max. op. cit., p. 7 [p. 49]).

${ }_{87}^{86}$ Suhrawardī, op. cit., par. 14 (Walbridge \& Ziai, p.9).

${ }^{87}$ Ibid., par. 14 (Walbridge \& Ziai, p.9).

${ }^{88}$ Ibid., par. 15 (Walbridge \& Ziai, p.10).

${ }^{89}$ Aristóteles examinou a definição como uma das quatro classes de predicáveis, se caracterizando por ser essencial e convertível com o definido. A base dessa classificação constitui-se nas noções de convertibilidade e de não convertibilidade e não essencialidade do predicado no que diz respeito ao sujeito: 1) relação do sujeito com o predicado convertível e essencial (= definição); 2) relação do
} 
existência, a definição tem como missão determinar a essência, isto é, aquilo que faz com que a coisa seja o que é, sua peculiaridade única. Nesse ponto é importante assinalar que mesmo Suhrawardī reelaborando tal argumentação contra a definição, nunca invalidou nem descartou a definição como forma de conhecimento. Em todo caso, ao discuti-la, procurou demonstrar seus limites e sua falta de adequação para se chegar a uma determinada certeza, como o fizeram os peripatéticos. Segundo Suhrawardī, o conceito peripatético de definição não é um método eficiente para conhecer a natureza essencial de algo, já que se deve considerar outros atributos como partes de sua identidade, mesmo que sejam esses acidentais. A definição inclui, portanto, não só a "essência", mas também outros elementos constitutivos. Assim, Suhrawardī afirma que "um enunciado $(q \bar{a} w l)$ é indicativo da essência de uma coisa (šay') e combina todos os seus elementos constitutivos. A respeito de sua realidade principal - seu enunciado - é uma síntese (tarkīb) de seu gênero e diferença." ${ }^{90}$ Isso é o que o distancia dos peripatéticos, já que seu argumento supõe que a identidade de uma coisa não somente consiste no que os peripatéticos entendiam por essência, mas inclui outros atributos que também são fundamentais.

Sobre a base dessas considerações, pode-se concluir que, já que nunca se pode conhecer todos os elementos constitutivos de um existente, então, antes de qualquer coisa, nunca se poderá defini-lo própria e adequadamente e, assim, não se pode obter um conhecimento seguro e real por meio desse método. Outro ponto decorrente: se a definição incluiria não apenas o gênero, mas também a diferença e outros elementos constitutivos, necessitar-se-ia de um conhecimento a priori da diferença, já que esta é uma propriedade exclusiva de um existente determinado.

A questão que Suhrawardī coloca é: mediante a inadequação do conceito peripatético de definição, então qual seria o método alternativo? O primeiro problema é que, para Suhrawardī, precisamente, a definição peripatética pretende ser “essencial”. Ao longo dessa primeira parte se procurará demonstrar que a diferença é propriedade exclusiva de um existente determinado. Então, se não se conhece o que é

sujeito com o predicado convertível e não essencial ( = propriedade); 3 ) relação do sujeito com o predicado não convertível e essencial ( = gênero ou diferença); 4) relação do sujeito com o predicado não convertível e não essencial ( = acidente).

${ }^{90}$ Ibid., par. 14 (Walbridge \& Ziai, p.9). 
essa propriedade, nunca se conhecerá sua identidade através de sua definição. Com efeito, estabelece-se que o conhecimento por definição só é possível se houver um primeiro princípio e que esse mesmo princípio não pode ter definição, por causa de sua natureza axiomática. Como será visto no primeiro tratado da segunda parte, esse fenômeno só ocorre com a luz, que é o que sustenta toda a epistemologia suhrawardiana. Quem conhece algo ou percebe um fenômeno, não necessita da definição e, se não o conhece, a definição não lhe ensinará nada a respeito do que é. A este respeito Suhrawardī afirma:

[...] assim, está claro que é impossível para um homem construir uma definição essencial no modo no qual quiseram os peripatéticos - uma dificuldade que seu próprio mestre [Aristóteles] admite. Portanto, obteremos definições só por meio das coisas que especificam por conjunção ou harmonia das partes $(\text { bill-ijtima })^{91}$.

Segundo Suhrawardī, para se obter o conhecimento de uma coisa (al-ma ${ }^{c}$ rĭfa almutayāqqīna), deve-se conhecer a totalidade dos essenciais (al-jāmic al-datiyyat). Isso não se pode produzir por um mero processo de enumeração de seus componentes, dado que há nas coisas que se quer conhecer uma grande multiplicidade de atributos (sīfat) que estão ocultos ( $\dot{g} a y r$ zahīra) e que pertencem à sua essência e natureza. Com isso, Suhrawardī responde à segunda questão, ao afirmar que há certo número de propriedades que em combinação e inter-relação - como é o caso das luzes identificam a coisa em questão como um todo orgânico, único, distinguindo-o de outros.

Ao rechaçar o conceito de "definição essencial" e ao sustentar, ao mesmo tempo, que o conhecimento deve ser produto da experiência direta, Suhrawardī desarticula o núcleo da noção de ciência na doutrina peripatética. A definição é baseada na experiência e não o contrário, por isso a definição é precária.

\section{Tratado II: Sobre as provas e os seus princípios}

\section{1) O ensinamento e os juízos}

\footnotetext{
${ }^{91}$ Ibid., par. 15 (Walbridge \& Ziai, p.11).
} 
Para Suhrawardī, uma proposição é uma expressão cujo enunciante pode ser qualificado como dizendo algo verdadeiro ou falso; um silogismo é uma expressão composta de juízos, de tal modo que se forma uma nova proposição, no momento em que se aceita as primeiras proposições ${ }^{92}$. Um “silogismo", continua Suhrawardī, é uma expressão composta de proposições que, quando aceitas, implica, essencialmente, outra expressão. A proposição simples é uma proposição "categórica", se ela contém uma decisão quanto à necessidade ou não de uma relação entre duas coisas para se vir a afirmar algo - por exemplo, "O homem é (ou não é) um animal”. A coisa julgada é chamada de "sujeito", e aquilo com que se julga é chamado de "predicado". Uma única proposição pode ser feita a partir de duas proposições que estão conectadas. Se elas estão ligadas por implicação, chama-se essa proposição de "condicional composta" - por exemplo, "Se o sol brilha, então é dia". A parte conectada à partícula condicional é chamada de "antecedente", e a parte conectada à partícula de conexão é chamada de "consequente". Para construir um silogismo a partir de uma proposição condicional, adiciona-se uma proposição categórica que afirma o antecedente e, assim, implica-se o consequente. Dessa maneira, "O Sol brilha” implica "É dia”. Se se puder adicionar o contraditório do consequente, implica-se o contraditório do antecedente. Dessa maneira, "Não é dia" implica "O Sol não brilha". Isso ocorre porque sempre existe alguma coisa que implica outra, então, necessariamente, o que está implicado também existe. Se o que está implicado não existe, assim, o que implica também não deve existir. No entanto, o consequente pode ser mais geral do que o antecedente, como em "Se este for preto, então é uma cor". A negação e a falsidade do mais específico não implicam a negação e a falsidade do mais geral, nem a afirmação e a verdade do mais geral implicam a afirmação e a verdade de que é mais específico. Pelo contrário, a afirmação e a verdade do que é mais específico implicam a afirmação e a verdade do mais geral, e a negação e a falsidade do mais geral implicam a negação e a falsidade do mais específico. Quando a ligação entre duas proposições categóricas é de alternância, a proposição composta é chamada de "condicional disjuntiva", como, por exemplo, "este número é par ou impar". Para se formar um silogismo de um condicional disjuntivo, alguém pode afirmar alguma parte da proposição, implicando,

${ }^{92}$ Ibid., par. 16 (Walbridge \& Ziai, p.12). 
dessa maneira, o contraditório do que resta. Se ele tiver muitas partes, afirmar o contraditório de um lado implica a disjunção das partes restantes.

Uma proposição conjuntiva pode ser composta por duas conjuntivas: "Se o sol brilha, então é dia; se o sol se pôs, é noite". Uma proposição disjuntiva pode também ser composta de duas conjuntivas condicionais: "Ou o sol brilha, sendo então dia; ou o sol se pôs, sendo então noite". Muitas outras combinações são possíveis. As proposições condicionais podem ser reduzidas a proposições categóricas ao estipular a implicação ou a alternância. Assim, Suhrawardī conclui: pode-se dizer que "o subir do sol indica que é dia; ou isso exclui que é noite" ${ }^{93}$. O condicional pode, assim, ser reduzido a proposições categóricas.

A relação entre predicado e sujeito pode receber determinadas modificações: a da necessidade (sempre), do impossível (jamais, nunca) e do possível (às vezes) ${ }^{94}$. A predicação precisa, com efeito, se diferenciar do impreciso, pois do contrário, por ser indefinida, implicará erros. Todos os juízos que se referem à predicação são afirmativos e necessários ${ }^{95}$ - a contingência dos contingentes, por exemplo, é necessária e a impossibilidade do impossível também o é. O necessário a respeito da impossibilidade do impossível pode ser afirmado a partir do contingente, mas não o necessário em respeito ao impossível como contingente.

O contingente é necessário em virtude daquilo que o necessita e é impossível na condição da não-existência do que necessita para a sua existência. Quando se examina uma coisa em si mesma nos dois estados de existência e não-existência, isso é contingente ${ }^{96}$.

A negação não é, assim, uma anulação do juízo, significando, porém, um juízo real. Por fim, Suhrawardī esclarece que "se deve entender por 'necessário' tudo aquilo que é o que é em virtude de sua essência. O que é necessário por condição de um tempo ou de um estado, é contingente em si mesmo"97. Já que a impossibilidade do impossível, a contingência do contingente e a necessidade do necessário participam de uma

\footnotetext{
${ }^{93}$ Ibid., par. 16 (Walbridge \& Ziai, p.13).

${ }^{94}$ Ibid., par. 17 (Walbridge \& Ziai, p.14).

${ }^{95}$ Ibid., par. 17 (Walbridge \& Ziai, p.14).

${ }^{96}$ Ibid., par. 19 (Walbridge \& Ziai, p.16).

${ }^{97}$ Ibid., par. 20 (Walbridge \& Ziai, p.17).
} 
relação complementar, deve-se fazer que estas três - partes de um todo - sejam uma proposição única e necessária em todas as circunstâncias. Assim, poder-se-á dizer que "necessariamente todos os homens são contingentemente letrados, necessariamente animais e impossivelmente pedras" $" 98$.

Esse segundo tratado, por conta do objetivo do livro, se propõe a discutir e apresentar o alcance e os limites da relação entre sujeito e predicado dentro de uma proposição predicativa que se estabelece a partir do necessário (wājīb), o possível (mumkin) e o impossível (mumtani $\left.{ }^{c}\right)$, conceitos chaves em sua elaboração metafísica. A noção de contingência em Suhrawardī é causal e dependente de sua metafísica e não pode ser expressa nos termos da lógica tradicional, porque toda a lógica demonstrativa peripatética, baseada na definição, se fundamenta em uma ausência de uma doutrina sobre a realidade. Por isso a lógica peripatética não serve para apreender o sentido lógico e profundo da realidade.

Para Suhrawardī, a contingência é um construto intelectual, sem realidade fora do intelecto. A luz das luzes é exatamente - como se argumentará na segunda parte do livro - absoluta, eterna e necessária e tudo se gera a partir dela. Os existentes gerados a partir da luz das luzes, ou seja, todo o cosmos - como se verá mais tarde -, são contingentes no sentido de que não existem necessariamente por si mesmos, por isso são dependentes. Suhrawardī esclarece que:

em uma proposição categórica a relação entre sujeito e predicado ou não pode não ser (em tal caso é chamado "o necessário" - wājīb), ou não pode ser (“o impossível" - mumtanic ${ }^{c}$ ou pode ser ou não ser (o possível - mumkin). Um exemplo do primeiro é "o homem é um animal"; do segundo "o homem é uma pedra", e do terceiro "o homem é letrado". Por "possível" o vulgo entende aquilo que é não impossível. Quando dizem "não impossível" querem dizer com isso o possível e, quando dizem "não possível", querem dizer "o impossível”. Entretanto, este não é o nosso tratamento, já que o possível, de acordo com nosso uso, pode ser ou não. Se a necessidade ou a impossibilidade de algo dependem de outra coisa, então se esta outra coisa for eliminada, não permanecerão nem a necessidade nem a impossibilidade e a coisa é

${ }^{98}$ Ibid., par. 21 (Walbridge \& Ziai, p.17). 
contingente em si mesma. O contingente é necessário em virtude daquele que o necessita e é impossível sob a condição do não ser daquilo que necessita sua existência. Quando alguém examina a coisa considerada em si mesma nos dois estados de ser e de não ser, isto é o "possível”. Por "necessário" entendemos aquilo que é em virtude de si mesmo. Aquilo que é necessário por condição de um tempo ou estado é contingente em si mesmo ${ }^{99}$.

Assim, wājīb, munkin e muntani $^{c}$ são termos que pertencem à ciência do significado intrínsico. $w a \bar{a} j \bar{l} b$ quer dizer uma necessidade absoluta. mumkin é uma possibilidade em tanto a existência como a não-existência se equivalem. muntani ${ }^{c}$ é uma impossibilidade em que a não-existência é uma absoluta necessidade ${ }^{100}$.

A contradição, precisa Suhrawardī, ocorre quando duas proposições diferem apenas pela afirmação ou pela negação. Segue-se, assim, que não podem ambas serem verdadeiras ou ambas serem falsas. ${ }^{101}$ A conversão, por sua vez, consiste em fazer do sujeito da proposição o predicado e do predicado o sujeito, enquanto mantém-se a qualidade e a verdade ou a falsidade da proposição. Quando se diz, por exemplo, “Todos os homens são animais" não se pode dizer "e todos os animais são homens"102. O mesmo é verdadeiro em cada preposição em que o sujeito é mais específico do que seu predicado. Mas, ao menos, o seguinte é verdadeiro: suponha-se que algo é descrito como sendo A e é descrito como sendo B - e se deixar essa coisa ser C, por exemplo. Então, uma vez que algo de A é B (se tudo ou uma parte) então algo de B (tudo ou uma parte) deve ser descrito como A; C será, portanto, descrito por A e B. Assim, quando se diz "Necessariamente todos os homens são contingentemente letrados", seu inverso será "Necessariamente alguma coisa que é contingentemente letrada é um

\footnotetext{
${ }^{99}$ Ibid., par. 19. (Walbridge \& Ziai, p. 16).

${ }^{100}$ Como veremos no próximo capítulo, para Suhrawardī, só há um só existente que é absolutamente necessário: a luz sagrada, a luz divina, a luz das luzes. Qualquer outra coisa é contingente na medida em que é dependente. Por exemplo: quando se afirma que há "a luz próxima". Nesse caso, esta primeira irradiação da luz das luzes, é necessária e contingente ao mesmo tempo, ou seja, uma consequência lógica e necessária da luz das luzes, sendo também contingente porque é um efeito possível e dependente da luz das luzes. O mesmo vale para as demais luzes, para os símiles platônicos, para as esferas e para tudo aquilo que procede da luz mais próxima. O impossível, aquilo que só pode não ser, é uma absoluta necessidade, é a obscuridade última e total. Assim, para Suhrawardī, a concepção de realidade é paralela e consequente com sua crítica ao silogismo tradicional.

${ }^{101}$ Ibid., par. 22. (Walbridge \& Ziai, p. 18).

${ }^{102}$ Ibid., par. 23. (Walbridge \& Ziai, p. 20).
} 
homem"103. Os outros modos além de contingência também modificam o predicado quando ele é convertido. O inverso da proposição definitiva afirmativa necessária é, em si mesma, uma proposição definitiva afirmativa necessária, qualquer que seja o modo.

\section{2) O ensinamento sobre a conclusão}

O silogismo não pode ser formado por menos de duas proposições ${ }^{104}$. Se uma das proposições inclui a conclusão inteira, a proposição é condicional e a outra proposição é afirmada ou negada. Esse é o "silogismo exclusivo". Se uma proposição corresponde a uma parte da conclusão, então a outra proposição deve corresponder à outra parte. O silogismo, nesse caso, é denominado como "conjuntivo". Nenhum silogismo, afirma Suhrawardī, consiste em mais de duas proposições ${ }^{105}$. Uma vez que cada uma das duas premissas corresponde a uma parte da conclusão, é impossível adicionar uma terceira. Como para os condicionais, no caso dos silogismos exclusivos, apenas a exclusão permanecerá. Com efeito, é possível haver muitos silogismos, todos que estabelecem as premissas de um silogismo. Quando uma proposição se torna parte de um silogismo, ela é chamada de "premissa". Em um silogismo conjuntivo, ambas as premissas devem compartilhar o "termo médio". Ambos, sujeito e predicado da premissa, são chamados de "termos". O termo médio pode estar no predicado de uma das premissas e no sujeito de outra, ou pode estar no sujeito de ambas ou no predicado de ambas. Os dois outros termos diferentes do médio são chamados de "extremos". A conclusão é obtida dos dois termos com o médio omitido. Quando o termo repetido isto é, o médio - é o sujeito da primeira premissa e o predicado da segunda premissa, é uma figura impossível cuja validade como um silogismo não é intuitivamente óbvia e é, assim, omitida. O silogismo conjuntivo perfeito, para Suhrawardī, é aquele em que o termo médio é o predicado da primeira premissa e o sujeito da segunda. Esse é o mais perfeito modo.

Referente à segunda figura do silogismo sempre que houver duas proposições universais com diferentes sujeitos, e o predicado de uma não puder ser afirmado da outra em todos os aspectos, ou mesmo em um aspecto, então é conhecido com certeza que, se um dos sujeitos puder ser concebido para ser incluído em outros, haveria sido

\footnotetext{
${ }^{103}$ Ibid., par. 23. (Walbridge \& Ziai, p. 20).

${ }^{104}$ Ibid., par. 24. (Walbridge \& Ziai, p. 21).

${ }^{105}$ Ibid., par. 24. (Walbridge \& Ziai, p.21).
} 
possível ao predicado da outra ser predicada dela ${ }^{106}$. A conclusão será, afirma Suhrawardī, definitiva e necessária, afirmando a impossibilidade de predicar o seu predicado de outro sujeito ou a necessidade da negação nele. As afirmações e negações serão, portanto, feitas partes do predicado, como em: "Todos os homens são necessariamente contingentemente letrados". Sabe-se, então, que "Todos os homens necessariamente são impossivelmente pedras". Nesse específico modo, portanto, não é condição que os predicados sejam o mesmo em cada aspecto. Os predicados necessitam só ser o mesmo no que eles compartilham para além do modo que é feito parte do predicado, e é, assim, permitido para os dois modos das duas premissas serem diferentes ${ }^{107}$. Para as frases negativas não há, segundo Suhrawardī, regras únicas, nas quais possam ser formadas o mesmo para o positivo, quando se transfere a negação para o predicado. Através dessa manipulação, o método de Suhrawardī é mais limitado do que o peripatético, e o diferencial das figuras se exclui ${ }^{108}$.

Sobre a terceira figura, Suhrawardī estabelece que quando se encontra uma coisa sozinha descrita por dois predicados, sabe-se já que, pelo menos, uma coisa do predicado é necessariamente descrita pelo outro predicado. Por exemplo, "Zayd é animal", e "Zayd é homem", disso se sabe, então, que "Algum animal é homem" e que "Algum homem é animal". A coisa específica deve consistir em um significado geral, então, se deve fazer uma proposição exaustiva, como em "Todos os homens são animais, e todos os homens são racionais". Isso será, então, restrito à coisa específica descrita por ambos, e segue que algo de um dos dois é o outro. Quando uma coisa particular é descrita por um ou por dois dos predicados e é específico e feito universal, então, o caso será o mesmo. A negação deve ser feita parte do predicado e transferida para a conclusão. O termo médio será descrito pelos dois extremos em cada posição dessa figura sem requerer uma proposição negativa. E se ambas as premissas contiverem negações, então, as duas negações deverão ser feitas partes dos dois predicados. Alguém pode dizer: "Todos os homens são não-pássaros, e todos os homens são não-cavalos". A conclusão é afirmativa: "Algo descrito como um nãopássaro é um não-cavalo". Se uma das premissas é universal e a outra não é, isso se

\footnotetext{
${ }^{106}$ Ibid., par. 25. (Walbridge \& Ziai, p.23).

${ }^{107}$ Ibid., par. 26. (Walbridge \& Ziai, p. 24)

${ }^{108}$ Max HORTEN, op. cit., p. 13 [p.55].
} 
torna possível se os sujeitos sobrepõem-se, pois o particular, em si mesmo, é incluído em "todos"109.

Os silogismos conjuntivos ${ }^{110}$ são compostos por condicionais, como na seguinte proposição composta: "Sempre que o sol se levanta, sabe-se que é dia; e sempre que é dia, as estrelas estão ocultas". Um silogismo pode também ser composto por uma proposição condicional e por uma categórica. O termo comum pode estar no consequente e o categórico na maior, como em "Se todos os $\mathrm{C}$ são $\mathrm{B}$, então todos os $\mathrm{E}$ são $\mathrm{D}$, mas todos os $\mathrm{E}$ são $\mathrm{A}$ ”. A conclusão será uma proposição composta condicional, cujo antecedente será o menor antecedente do próprio silogismo, e seu consequente será o resultado da combinação do consequente e do categórico, como "Se todos os C são B, então todos os E são A".

O silogismo que mostra a verdade da conclusão provando a falsidade de seu contraditório é chamado de "redução ao absurdo". Este é composto de dois silogismos, um categórico e um exclusivo, como em "Se é falso que nenhum $\mathrm{C}$ é B, então alguns C são B e todos os B são A". Se a premissa é verdadeira, então a conclusão será: "Se é falso que nenhum C é B, então alguns C são A”. Poder-se-ia fazer essas proposições universais, ao fazer universais as contraditórias da conclusão desejada, qual que seja a consequente da condicional. Em seguida, o contraditório da consequente será excluído assim que o contraditório da antecedente for o resultado, tal qual assim: "Não é falso que nenhum C é B; em vez disso, é verdade". Na "redução ao absurdo", afirma Suhrawardī ${ }^{111}$, é óbvio que uma conclusão absurda não pode ser inferida de duas premissas ou de sua combinação. O contraditório da conclusão desejada implica o absurdo.

\section{3) Sobre as provas entre as ciências e sobre as induções (completas e incompletas)}

A seguir, Suhrawardī passa a discorrer sobre os silogismos demonstrativos ${ }^{112}$. As ciências são oriundas exclusivamente da demonstração apodítica, a qual se compõe de premissas seguras. Entre os peripatéticos, as condições para uma verdadeira demonstração são que as premissas decorram em, primeiro lugar, dos primeiros

\footnotetext{
${ }^{109}$ Suhrawardī, op. cit., par. 27. (Walbridge \& Ziai, p. 25).

${ }^{110}$ Ibid., par. 28 (Walbridge \& Ziai, p. 25).

${ }^{111}$ Ibid., par. 29. (Walbridge \& Ziai, p. 26).

112 Ibid., par. 30 (Walbridge \& Ziai, p. 26).
} 
princípios do pensamento; em segundo lugar, das coisas diretamente percebidas (sempre particularmente); em terceiro lugar, das experiências ensinadas; em quarto lugar, das suposições que têm sua origem em indícios seguros; em quinto lugar, das tradições que se apoiam em uma corrente ininterrupta; em sexto lugar, dos juízos que chegam a conclusões por meio de silogismos, por exemplo, de que o número 4 é um número par $^{113}$. Suhrawardī, por sua vez, reduz as condições de seis pontos para três: em primeiro lugar, o conhecimento manifesto; em segundo lugar, a percepção interior e exterior; em terceiro lugar, os indícios seguros.

As premissas que se sabe com certeza podem ser "primárias"; essas são as premissas cujo assentimento é conferido simplesmente ao conceber seus termos e cuja verdade ninguém pode negar após seus termos haverem sido entendidos. Exemplos são os juízos que "O todo é maior que as partes" ou que "preto" e "branco" não podem ser ditos sobre a mesma coisa no mesmo tempo e lugar ${ }^{114}$. As premissas "percebidas" podem ser conhecidas por meio da apreensão dos sentidos internos ou externos. Tais premissas percebidas não são probatórias para alguém que não teve a mesma apreensão. As premissas podem também ser "intuitivas". De acordo com o princípio iluminacionista, as premissas intuitivas são de vários tipos. O primeiro são as premissas empíricas: coisas observadas com tal frequência para produzir certeza e fazer que se confie que estes não poderiam ocorrer por acaso - por exemplo, o juízo "ser atingido com uma vara é doloroso". Essa conclusão não é atingida por indução, pois a indução é a conclusão sobre um universal baseado em muitos particulares. Uma vez que a indução é uma expressão para esse tipo de juízo, não se sabe, então, que o juízo "nenhum homem viverá se sua cabeça é cortada fora" é apenas a conclusão em relação ao universal baseada em muitos particulares. A indução pode conduzir à certeza se há um só exemplo, como acabou de ser mencionado; mas se está relacionada com diferentes espécies, a indução pode não levar à certeza. O juízo que todos os animais movem a mandíbula inferior ao comer, pode ser falso, porque é possível que se observe um animal que seja uma exceção a essa regra - como um crocodilo -, diferente de tudo aquilo que se havia já observado ${ }^{115}$.

\footnotetext{
${ }^{113}$ Max HORTEN, op. cit., p. 13 [p. 55].

${ }_{114}^{114}$ Suhrawardī, op. cit., par. 30 (Walbridge \& Ziai, p. 26).

${ }^{115}$ Ibid., par. 30 (Walbridge \& Ziai, p. 27).
} 
O segundo tipo de premissa intuitiva é a premissa "tradicional". Essa é a proposição de que um homem pode se sentir seguro, em razão de uma grande frequência de testemunhos. A própria certeza é a evidência de que o número de testemunhos é suficiente. Não cabe à lógica definir o número em alguma quantidade fixa, porque a certeza, muitas vezes, é obtida de um pequeno número. As associações têm algo a ver com todas essas coisas, e o homem adquire uma intuição por meio delas. As intuições, afirma Suhrawardī, não são a prova de algo ${ }^{116}$. Muitas vezes a faculdade estimativa do homem faz um juízo sobre algo que acaba por ser falso, tais como a negação da alma, do intelecto e do existente não-espacial. Ela pode ajudar o intelecto através do fornecimento de premissas que impliquem seu inverso, quando então o intelecto aceita aquilo que rejeitou. No entanto, cada juízo estimativo que contradiz a razão é falso, e a razão nunca afirma o que implica uma contradição com outra coisa que havia já deduzido.

As premissas "aceitas universalmente" não são sempre conhecidas de maneira inata $^{117}$. Algumas delas podem ser comprovadas para serem verdadeiras - como o juízo que a ignorância é abominável - ao mesmo tempo em que outros são falsos. A primeira premissa pode também ser universalmente aceita.

Outras proposições que podem ser usadas como premissas são as aceitas em geral por todos que detém a mesma opinião. Algumas premissas não conduzem a um assentimento; mas são afetadas por sentimentos. São chamadas de "imaginativas", tal qual o juízo de que o mel é amargo e causa vômito ${ }^{118}$. Outras proposições enganam as pessoas e causam dúvidas, a fim de se criar a crença em falsidades.

A demonstração usa apenas premissas conhecidas com certeza - premissas conhecidas de maneira inata ou baseadas em premissas conhecidas anteriormente de maneira inata em um silogismo válido. Assim, as matérias que não levam a um conhecimento lógico seguro são: em primeiro lugar, os construtos sobre as coisas que não são perceptíveis, como por exemplo, para além do cosmos há um espaço vazio; em segundo lugar, as coisas geralmente conhecidas; em terceiro lugar, os

\footnotetext{
${ }^{116}$ Ibid., par. 30 (Walbridge \& Ziai, p. 27).

117 Ibid., par. 30 (Walbridge \& Ziai, p. 28).

${ }^{118}$ Ibid., par. 30 (Walbridge \& Ziai, p. 28).
} 
ensinamentos aceitos em razão de sua autoridade; em quarto lugar, as imaginações construídas; em quinto lugar, as frases prováveis e, no entanto, inseguras; em sexto lugar, as percepções incertas.

\section{4) Sobre as analogias}

A seguir, Suhrawardī passa a discorrer sobre a analogia. Esta consiste em uma referência a uma lei relacionada com a particularidade de uma coisa ${ }^{119}$. A analogia, por sua vez, não pode produzir certeza. Trata-se de um argumento que exige que um predicado seja comum a duas coisas com base em um elemento comum a ambas. Os peripatéticos identificam dois métodos na analogia. No primeiro, onde quer que o significado comum seja encontrado, então esse predicado é associado a ele - e viceversa -; portanto, estão conectados no ponto em questão. No entanto, os peripatéticos não conseguem, constata Suhrawardī, explicar porque esses dois devem ser inseparáveis em algumas outras circunstâncias não consideradas na prova. No segundo método, eles enumeram alguns atributos daquele em que o predicado passa a existir. A isso os peripatéticos denominam como "raiz" ou como "evidência".

Eles [os peripatéticos] não estão certos de que eles mesmos não esqueceram nenhum atributo que fosse a base do predicado. Muitos predicados dependem de algo que se tornará ciente somente mais tarde. [Os peripatéticos,] então, passam a afirmar que todas as coisas particulares, exceto o que para o predicado é relatado na "raiz", são incapazes de causar o predicado. Podem também afirmar que aquele ao qual o predicado está relacionado é independente dos atributos em causar o predicado em outro contexto. Eles podem tentar eliminar tudo diferente ao qual o predicado está relacionado, ainda havendo a probabilidade de continuar seus seres na raiz, devido à sua especificidade e individualidade - não devido a um significado que pode ser transcendido e não por causa de uma coleção de atributos que fosse mais abrangente, porque, certamente, contém a causa. [...] Também é possível que o que eles especificam possa ser dividido em duas classes, na qual o predicado é correlato a apenas um deles, e em que a correlação não existe na ausência do elemento comum. Isso é semelhante ao caso anterior, havendo risco de negligenciar algum atributo que é realmente a base do predicado. [...] Os

${ }^{119}$ Ibid., par. 31 (Walbridge \& Ziai, p. 28). 
peripatéticos rejeitam a possibilidade de um predicado geral causado em lugar diferente por causas diferentes, e eles oferecem provas contra isso. No entanto, a base de sua prova, em si mesma, é a analogia, por meio da qual eles afirmam o que alguns também por analogia se baseiam. ${ }^{120}$

Ademais, se é possível a um único predicado geral ter múltiplas causas, então, seu princípio - que a causa da evidência é a causa da coisa ausente - deve ser falho. A existência de condições também torna admissível para uma coisa geral ou particular ter condições alternativas e causas. Outro dos princípios peripatéticos criticados por Suhrawardī é o que indica que algo em evidência também indica a coisa ausente. Para isso, pode ser respondido que, se a indicação de algo for essencial para o predicado geral, então, sua relação seria a mesma para a evidência e a coisa ausente, e não haveria nenhuma necessidade de analogia. Mas se a especificidade da evidência tem algo a ver com a indicação ou com o estabelecimento das indicações, o argumento anterior se aplica à especificidade.

A demonstração em que o termo médio é a causa da relação entre os termos maior e menor em ambas as realidades - a intelectual e a concreta - é denominada "causal" ${ }^{121}$. Essa é a causa da relação entre os dois extremos apenas no intelecto - ou seja, é a única causa do assentimento -, sendo denominada "demonstrações assertivas", porque mostra apenas que a proposição é o caso, mas não porque é assim em si mesmo. Pode acontecer que o termo médio seja causado pela relação em realidade concreta, mas isso é mais manifesto para nós, tais como: “esta vara está queimando, e tudo aquilo que queima deve ter sido tocado pelo fogo; logo, esta vara foi tocada pelo fogo." 122

O conhecimento consiste em um conceito ou em um juízo. O método do conhecimento tem a intenção de um conceito - aí valem as condições "do que" e do "como" - ou esse conhecimento quer atingir um juízo - aqui vale o "se" e o "porquê" 123 .

\footnotetext{
${ }^{120}$ Ibid., par. 31 (Walbridge \& Ziai, pp. 28-29).

${ }^{121}$ Ibid., par. 32 (Walbridge \& Ziai, p. 29).

${ }^{122}$ Ibid., par. 32 (Walbridge \& Ziai, p. 30).

${ }^{123}$ Ibid., par. 32 (Walbridge \& Ziai, p. 30).
} 


\section{Tratado III. Os sofismas}

\section{1) Os tipos de erro}

O erro pode ocorrer em um silogismo quando sua disposição não consiste em um dos modos válidos ${ }^{124}$. Há, dessa maneira, erros que podem ocorrer porque a negação está demasiadamente adiantada ou tardia ou repetitiva,

como quando o vulgo supõe que "não necessariamente" e "necessariamente não" são a mesma coisa. Isso é um erro, porque o primeiro é o verdadeiro da coisa contingente, enquanto o segundo não o é. Da mesma maneira, "Não se segue que..." não é o mesmo que "Segue-se que não..." O que não é contingente pode ser necessário, em sua existência ou em sua inexistência. Isso é diferente de algo que é contingentemente inexistente, porque uma coisa também é contingentemente existente. Se "contingência" significa aquilo que não é impossível - "contingência geral" - a afirmativa não pode ser convertida em uma negativa, nem a negativa em uma afirmativa. [...] As negações, com efeito, causam muitos erros ${ }^{125}$.

Há erros, segundo Suhrawardī, que também podem ocorrer por causa da quantificação, como quando "algum" da quantificação é usado no lugar do "algum" referente à parte real, ou quando "qualquer", "todo" e "todos" são usados alternadamente. Assim, erra-se ao se combinar o que é separado, como quando a expressão "Zayd é um físico e é bom” é tomada para implicar que Zayd é um bom físico, ou por separar do composto, como quando "Cinco é um número ímpar mais constante" é tomado para implicar que cinco é ímpar e constante. Os erros podem também ocorrer quando alguém pensa que um dos dois concomitantes é outro, ou que um deles é a causa do outro - como nas faculdades humanas de rir e de ler e escrever.

Essa falácia é muito comum entre aqueles que não dominam as ciências [...] Tais erros levam frequentemente a círculos viciosos. Por exemplo, diz-se que não pode haver nenhuma paternidade sem que haja um filho e nenhum filho sem paternidade; por conseguinte, desde que cada um depende do outro, há uma circularidade. Isso é errôneo, porque eles são simultâneos. Uma dependência impossível só poderia ocorrer se cada um existisse por causa do

\footnotetext{
${ }^{124}$ Ibid., par. 34 (Walbridge \& Ziai, p.31).

${ }^{125}$ Ibid., par. 36 (Walbridge \& Ziai, p.32).
} 
outro, o que implicaria que cada era antes do outro e assim anterior a si mesmo. ${ }^{126}$

Há erros também quando um concomitante específico de uma coisa é tomado como sendo um universal, estabelecendo o que há de comum entre as várias coisas, como quando alguém diz "O preto reúne a visão porque é cor" e diz o mesmo sobre o branco $^{127}$. Os erros podem também ocorrer quando o real é tomado como sendo virtual, ou vice-versa; quando algo essencial é tomado como sendo acidental, ou viceversa; ou quando construtos intelectuais ( $\left.i^{c} t i b \bar{a} r \bar{a} t{ }^{c} a q \bar{l} \bar{y} a\right)$ e predicados intelectuais são tomados como existentes concretos - como quando alguém ouve "O homem é universal" e pensa que seu existente universal é algo predicável disso como algo concreto por virtude dos existentes descritos por humanidade; ou quando a imagem de uma coisa é tomada no lugar da própria coisa; ou quando parte da causa é tomada no lugar da causa; ou quando em uma redução ao absurdo uma coisa que não é a causa da negação da conclusão é tomada como sendo. Da mesma maneira, para Suhrawardī, a utilização pouco rigorosa dos termos técnicos

pode também levar a erros quando algo igual é aplicado para diferentes espécies, como quando alguém diz "Uma vez que os homens e os peixes enquanto animais são semelhantes, os homens não respiram necessariamente mais do que os peixes." Esse método pode também levar ao erro quando é aplicado no reino do acaso, como em "Zayd e ${ }^{\mathrm{c}} \mathrm{Amr}$ são igualmente susceptíveis de altura, uma vez que são ambos humanos; portanto, um deles não pode ser mais alto do que o outro", desde que alguém não perceba que há motivos desconhecidos para nós que necessitam ou fazem impossíveis matérias que são contingentes, como demonstraremos mais tarde. Dentro de uma única espécie em que os indivíduos diferem pela perfeição e deficiência, esse tipo de argumento não se aplica; um particular pode ser em si mesmo digno de algo devido à sua própria perfeição. A natureza dessa perfeição será discutida posteriormente. ${ }^{128}$

\footnotetext{
${ }^{126}$ Ibid., par. 37 (Walbridge \& Ziai, pp.32-33).

${ }^{127}$ Ibid., par. 39 (Walbridge \& Ziai, p.33).

${ }^{128}$ Ibid., par. 39 (Walbridge \& Ziai, p.34).
} 
Os erros ocorrem, continua Suhrawardī ${ }^{129}$, quando algo impossível é postulado como existindo para provar algo com respeito ao sentido em que é impossível. Os erros podem ocorrer por causa da desatenção ao sentido dado em cada palavra usada, como quando alguém diz, "A brancura está incluída no conceito de cada coisa branca, e Zayd é branco", implicando que a brancura está incluída na realidade de Zayd. A verdade é que a brancura está incluída no conceito da coisa branca na medida em que a coisa é branca, não na medida em que é humano ou animal - então não é possível incluir Zayd na realidade da coisa branca ${ }^{130}$.

Outro erro comum é quando a privação oposta é confundida com o contrário ${ }^{131}$. O repouso, por exemplo, é a não existência de movimento apenas no que pode moverse. A cegueira é uma expressão que indica a falta de visão apenas em uma coisa que pode ser concebida como tendo a visão. Uma pedra, que não pode ser concebida como tendo visão, não pode ser dita "cega"132. Alguns nomes de privações - como "inefabilidade" e "exclusividade" - não são condicionados à contingência, porque eles são nomes de negações. Outros se limitam apenas a partes de uma espécie - por exemplo, ter ou não ter barba. Outros, tais como a cegueira e o repouso, são condicionados à contingência. No entanto, os termos específicos são usados de diferentes maneiras. Assim, o erro consiste em confundir a afirmação e a negação com a privação e a possessão. Tudo está sujeito à afirmação e à negação, ao contrário de privação e de posse. Por exemplo, se pode muito bem dizer "A pedra não vê", mas jamais se poderá dizer "A pedra é cega".

Uma vez estabelecida as confusões que muitos, principalmente "os seguidores dos peripatéticos", tomam ao utilizar termos lógicos, Suhrawardī passa a buscar solucionar os problemas apresentados:

a) Uma falácia conhecida consiste em perguntar como se sabe que a coisa desconhecida que alguém acaba de apreender em seu intelecto é o que realmente esse alguém havia procurado apreender - o que implica que esse deveria ser ignorante ou, então, que o conhecimento já existia antes da apreensão. Esse erro se deve também à

\footnotetext{
${ }^{129}$ Ibid., par. 40 (Walbridge \& Ziai, p.34).

${ }^{130}$ Ibid., par. 40 (Walbridge \& Ziai, p.34).

${ }^{131}$ Ibid., par. 42 (Walbridge \& Ziai, p.35).

${ }^{132}$ Ibid., par. 42 (Walbridge \& Ziai, p.35).
} 
falta de clareza sobre a existência e seus modos; pois o que se pretende é desconhecido em todos os aspectos, não podendo, se assim for, ser procurado - nem poderia ser procurado se for conhecido em todos os aspectos ${ }^{133}$. Em vez disso, ele deve ser conhecido em alguns aspectos e desconhecido em alguns outros aspectos que podem ser especificados por aquilo que já se sabe de antemão. Isso se aplica apenas a proposições e assentimentos. Por exemplo, quando se pergunta, "É o universo contingente?" se busca não mais do que um julgamento especificado por esses conceitos. Por outro lado, quando alguém ouve o nome dado a alguma coisa, procura saber o seu significado e é dito que corresponde a tal e tal nome um significado, ele não adquire conhecimento da coisa apenas por ouvir que esse nome é o que ele havia procurado. Da mesma maneira, quando alguém concebe uma coisa através de um dos seus concomitantes e realmente não a viu, ele pode estar em dúvida sobre seus outros atributos, mesmo depois que se faz a descrição para esse alguém. Continua Suhrawardī:

Suponhas que alguém soubesse por certos [homens] que um pássaro chamado "fênix" existe, mas não o viu e procura conhecê-lo em sua especificidade. Esse alguém saberá apenas os atributos gerais do pássaro - que ele voa, por exemplo. Somente por meio de muitas pessoas, dizendo-lhe que os outros atributos do pássaro chamado "fênix" são tais e tais pode ele saber tão bem que ele pode dizer que o mencionado por alguém lhe descrevendo todos os atributos pertencem ao que ele procura e nada mais ${ }^{134}$.

b) Sabe-se que a universalidade de uma regra indicando que algo está subordinado a outra coisa é refutada por uma única instância em que a segunda coisa está ausente. A universalidade de uma lei, declarando a impossibilidade de algo que está sendo vinculada a outra coisa, é comprovada pela existência daquela coisa em um único caso. Assim, constata Suhrawardī,

se alguém afirma que cada $\mathrm{C}$ é necessariamente $\mathrm{B}$ e encontra um único $\mathrm{C}$ que não é $B$, então a universalidade da regra é refutada. Da mesma maneira, se alguém afirma que é impossível para qualquer $\mathrm{C}$ ser B, mas, em seguida, encontra um único $\mathrm{C}$ que é $\mathrm{B}$, a lei há de ser refutada. No entanto, se alguém

${ }^{133}$ Ibid., par. 46 (Walbridge \& Ziai, p.37).
${ }^{134}$ Ibid., par. 46 (Walbridge \& Ziai, p.37). 
afirma que qualquer $\mathrm{C}$ pode ser $\mathrm{B}$, isto não é refutado nem pela existência nem pela ausência de instâncias. Assim, alguém deve reclamar que algum universal é contingentemente verdadeiro de outro universal - por exemplo, afirmando a quididade de $\mathrm{C}$ - em seguida, ele precisa encontrar uma única instância em que é B e outra que é não B, a fim de mostrar que o B universal é impossível na natureza de $\mathrm{C}$ (pois caso contrário, nenhum $\mathrm{C}$ particular poderia ser descrito como sendo B) e que [B] é não-necessário [em C] (pois nesse caso nenhum $\mathrm{C}$ particular poderia deixar de ser $\mathrm{B})^{135}$.

c) A negação de alguma coisa é existencial na medida em que é uma negação no intelecto e um juízo racional, e o assentimento não é apenas uma relação afirmativa que se subdivide em negação ${ }^{136}$. Por conseguinte, o assentimento permanece mesmo após a negação. Essa relação contínua do assentimento durante a negação não é a relação comum de afirmação. Assim, a negação é um juízo existencial - ou seja, a negação tem uma existência no intelecto, embora ela própria quebre alguma outra afirmação.

\section{2) Referências ao ensinamento dos seguidores dos peripatéticos}

\subsection{1) A descrição do significado dos termos técnicos}

Nos dois primeiros tópicos do terceiro tratado, Suhrawardī realiza um exame crítico das falácias que interessam conforme as características de sua análise, para sua crítica aos peripatéticos. Todavia, é muito significativo o terceiro tópico no marco dos objetivos traçados por Suhrawardī, na medida em que contêm refutações a dez doutrinas peripatéticas específicas, formando um verdadeiro compêndio do que Suhrawardī denominou "juízos” (hukūma).

Suhrawardī começa a terceira seção afirmando que "para avançar em nosso objetivo, prolongaremos esta seção com uma introdução estabelecendo alguns termos técnicos"137. São estes:

a) $\mathrm{O}$ "contingente" significa que uma coisa é produto de uma causa:

\footnotetext{
${ }^{135}$ Ibid., par. 48 (Walbridge \& Ziai, p.38).

${ }^{136}$ Ibid., par. 49 (Walbridge \& Ziai, pp.39-40).

${ }^{137}$ Ibid., par. 51 (Walbridge \& Ziai, p. 42).
} 
uma coisa pode ser necessária ou contingente. O contingente é aquilo que por si mesmo não tem razão suficiente para ser existente ou não-existente, mas sua razão suficiente é outra coisa. A razão suficiente para um existente é a presença de sua causa ${ }^{138}$.

Contingência é, portanto, dependência.

b) Uma causa é, com efeito, anterior a seu efeito:

por "causa" entendemos aquilo cuja existência imediatamente e sem demora produz a existência de outra coisa. Deve haver simultaneidade no tempo [...] Também há uma prioridade que é temporal, seja de lugar, seja de posição como é o caso dos corpos. Uma parte da causa pode ser temporal ou intelectualmente anterior ${ }^{139}$.

c) Uma causa pode ser composta e inclui condições e eliminação de impedimentos:

condições e recusa dos impedimentos também entram dentro da causa; se o impedimento ou obstrução não são eliminados, a existência de uma coisa é ainda contingente em relação com o que se assumiu como causa. Se sua relação (de impedimento) forma parte da contingência sem deixar a condição de razão suficiente, não pode haver relação entre causa e efeito. Isto significa que a não existência entra na causalidade no sentido de que, quando o intelecto considera a necessidade do efeito, não pode fazê-lo sem considerar a não existência do impedimento ${ }^{140}$.

d) Uma ordem infinita real, ordenada e simultânea é impossível, contudo, Suhrawardī afirma:

saibam que qualquer série que tem uma ordem - seja qual for - e cujos individuais são coexistentes, deve ser finita. A razão para isso é que se há um número infinito de itens entre dois membros da série, este número infinito de membros deve estar contido entre os dois limites em uma ordem, o que seria absurdo $^{141}$.

\footnotetext{
${ }^{138}$ Ibid., par. 54 (Walbridge \& Ziai, p.43).

${ }^{139}$ Ibid., par. 54 (Walbridge \& Ziai, p.43).

${ }^{140}$ Ibid., par. 54 (Walbridge \& Ziai, p.44).

${ }^{141}$ Ibid., par.55 (Walbridge \& Ziai, p.44).
} 
Enquanto Suhrawardī elabora seu argumento contra a existência infinita de uma série de seres dependentes e contingentes, ao mesmo tempo sustenta que a divisibilidade dentro de um jogo com um princípio e um fim, pode existir.

\subsection{2) A existência e o existente}

A "existência" (wujūd), afirma Suhrawardī, é usada com um significado unívoco e como um conceito único para muitas coisas, como pretidão e substância ou homem e cavalo. É um significado inteligível mais geral que qualquer outro destes, como são também os conceitos de quididade, coisidade, e a realidade tomados de maneira absoluta. Suhrawardī insiste que todos esses predicados são puramente intelectuais $^{142}$. Por conseguinte,

se a "existência" $(w u j u \bar{c})$ fosse apenas uma expressão para a pretidão, não poderia ser aplicada com o mesmo significado à pretidão, à brancura e à substância. Se fosse considerada como sendo um significado mais geral que a substancialidade, ou seria de qualquer subsistente na substância ou independente em si mesma. Se fosse independente em si mesma, então a substância não poderia ser descrita por "existência", porque sua relação com a substância seria a mesma que sua relação com qualquer outra coisa. Se fosse na substância, seria certamente atual nela, e a atualidade seria certamente a existência. Se a existência fosse atual, seria existente. Se seu "estar existente" fosse tomado como sendo uma expressão para a existência mesma, então "existente" (mawjūd) não se aplicaria para a existência e outras coisas com o mesmo significado. Isso porque o conceito de existente com respeito às coisas é que um existente é algo tendo ${ }^{143}$ existência, enquanto no caso da existência mesma seria aquela que é a existência. Nós próprios não dizemos algo de muitas coisas, a não ser com um só significado. Em seguida, defendemos que pretidão é não-existente, então sua existência não é real. Por conseguinte, sua existência não é existente, uma vez que sua existência é também nãoexistente. Se inteligirmos a existência e julgarmos que não é existente, então o conceito de existência é distinto do conceito de existente. Poderíamos dizer que a pretidão, que havíamos tomado como não-existente, agora existe e que

\footnotetext{
${ }^{142}$ Ibid., par.56 (Walbridge \& Ziai, p.44).

${ }^{143}$ Grifo nosso.
} 
sua existência não era atual ainda, e então sua existência se tornou atual. Se assim for, a atualidade da existência não seria a existência mesma, e a existência teria existência. Esse mesmo argumento se aplica à existência da existência, e assim por diante até o infinito. No entanto, uma infinidade de atributos ordenados simultaneamente é absurda ${ }^{144}$.

Outra consideração é que os seguidores dos peripatéticos compreendem a existência, no entanto, duvidam que seja real em coisas concretas, tal como acontece com a quididade original. A existência teria outra existência, resultando em uma regressão. É claro, conclui Suhrawardī, que não há nada na existência que pudesse ser a quididade da existência. Se a existência tivesse uma quididade, existiria outra existência - e assim, haveria uma regressão infinita ${ }^{145}$.

Suhrawardī conclui ${ }^{146}$ que "existente" e "existência" são duas coisas separadas; que a existência pode ser apenas concebida em relação a um existente e que os existentes precedem a existência. Já que a existência é um conceito universal requerido por um existente em uma ordem determinada para manifestar a si mesmo e dado que os existentes requerem uma quididade para ser existente, então a quididade deve preceder a existência. Já que a quididade é necessária para que algo seja existente e a existência é contingente em relação ao existente, a existência é, assim, contingente no que diz respeito à quididade. Suhrawardī criticou e rejeitou a distinção lógica operada pela escola peripatético-árabe entre quididade e existência em uma coisa concreta $^{147}$, insistindo que o conceito de existência é adicionado à quididade, tal que a extensão geral do conceito de existência continua a ser um construto intelectual, não sendo algo real e concreto. Em outras palavras, para Suhrawardī, conceitos como

\footnotetext{
${ }^{144}$ Ibid., par.56 (Walbridge \& Ziai, p.44).

${ }^{145}$ Ibid., par.57 (Walbridge \& Ziai, p.44).

${ }^{146}$ Ibid., par. 56 (Walbridge \& Ziai, p.45).

147 Para Suhrawardī, a existência de uma distinção intelectual válida logicamente não implica a existência correspondente de uma distinção real nas coisas concretas. São construtos intelectuais, sem realidade fora do intelecto; apenas existentes individuais concretos existem concretamente. Muitos filósofos árabes posteriores criticaram a tese da primazia da quididade de Suhrawardī, observando que a quididade considerada em si mesma constitui também um construto intelectual, assim como a existência. Mullā Șadra observou a confusão que Suhrawardī haveria feito entre o conceito de existência e a realidade da existência e substituiu a noção suhrawardiana de luz - para Suhrawardī, em última instância, apenas trevas (entendidas como ausência de luminescência e de iluminação) e luzes existem concretamente - pela noção de existência, um ecletismo entre a metafísica aviceniana e a cosmologia iluminacionista.
} 
existência quando considerados a priori são construtos meramente intelectuais, com nenhuma realidade correspondente fora do intelecto.

Suhrawardī procura aqui demonstrar que a existência não tem realidade e que sua presença deriva das coisas existentes, as quais devem sua entidade à sua quididade $^{148}$. Este é o argumento denominado "conhecimento pela presença", base de toda doutrina iluminacionista e que será ampliada em toda a segunda parte do Livro da sabedoria da iluminação.

\subsection{3) A identificação por meio da cópula}

Alguns peripatéticos ${ }^{149}$, constata Suhrawardī, argumentam que se pode pensar o homem sem existência, mas não se pode pensá-lo sem uma relação com a animalidade. Ainda a relação da animalidade com a humanidade não significa nada, exceto que sejam existentes em algum homem ou animal, na realidade concreta ou no intelecto. Assim, os peripatéticos apontam duas existências na relação da animalidade com a humanidade: uma pertencente à animalidade que está em todo homem; e a segunda, que se torna existente na humanidade em virtude da existência da humanidade. Ademais, ensinaram que partes da essência, como, por exemplo, a animalidade e a racionalidade são essenciais para o homem. Construíram uma metafísica geral a partir do conceito de existência, embora o mesmo se predique de suas essências diversificadas e por isso só pode ser um conceito lógico, sem realidade concreta. A limitação dos seguidores dos peripatéticos, para Suhrawardī, está em construírem sua metafísica a partir da existência, que não passa de mero construto intelectual. Suhrawardī esclarece, então, que

a "existência" pode ser dita das relações das coisas, como quando alguém diz que algo é existente na casa, no mercado, no intelecto, na realidade concreta, no tempo, ou em um local. Aqui a palavra "existência" ocorre com a palavra "em" com o mesmo significado em todos esses. A "existência" pode ser usada como uma cópula, como quando alguém diz "Zayd existe ao escrever". Pode ser dito da realidade e da essência, como quando alguém diz "A essência da coisa e de sua realidade, a existência da coisa, sua concretude, e ela em si mesma". Esses são

\footnotetext{
${ }^{148}$ Ibid., par. 56 (Walbridge \& Ziai, p.45).

${ }^{149}$ HORTEN, Max. op. cit., p.61 [p.19].
} 
tomados como construtos do intelecto e são aplicados às quididades externas. Isso é o que muitas pessoas entendem por "existência", mas os peripatéticos dão outro significado, eles estão no hábito de explicar isso em seus argumentos, com vista para o fato de que eles também tinham assumido que é o mais manifesto das coisas, não definível por qualquer outra coisa $^{150}$.

Assim, o ser copulativo não é nada mais do que um ente lógico - o que já constitui outro problema para a ciência peripatética.

\subsection{4) A natureza puramente lógica de todos os construtos intelectuais}

Também, prossegue Suhrawardī, a contingência é uma coisa anterior no intelecto à sua existência, pelo fato de os contingentes serem contingentes e, em seguida, existirem. Não é correto dizer que eles existem e, em seguida, tornam-se contingentes $^{151}$. A contingência aplica-se com um único significado a coisas de diferentes tipos; por isso é acidental para a quididade, e a quididade é descrita por ela. Assim, a contingência não é algo subsistente por si mesma. Não é um existente necessário, uma vez que se sua existência fosse necessária em si, seria subsistente por si mesma e assim não precisaria de uma relação com um sujeito. Assim, sua contingência não é uma coisa em si mesma. ${ }^{152}$. O mesmo ocorre com a necessidade, uma vez que a necessidade é um atributo da existência. Se fosse adicionada à existência e não fosse autossubsistente, ela seria contingente e teria tanto a necessidade quanto a contingência. Suas contingências particulares e necessidades formariam uma ordenação infinita. A necessidade da coisa seria anterior a ela e não seria a coisa em si mesma, desde que a coisa seja necessária e então exista; ela não existiria e então se tornaria necessária. Então, também, a existência teria necessidade, e a necessidade existência. Haveria, pois, outra regressão de existências repetidas da necessidade e da necessidade da existência. ${ }^{153}$

As relações também são construtos da razão ${ }^{154}$. Da mesma maneira, as privações - repouso, por exemplo - são também coisas de natureza puramente

\footnotetext{
${ }^{150}$ SUHRAWARDİ, op. cit., par. 60 (Walbridge\&Ziai, p.47).

${ }^{151}$ Ibid.., par. 63 (Walbridge\&Ziai, p.48).

${ }^{152}$ Ibid., par. 63 (Walbridge\&Ziai, p.48).

${ }^{153}$ Ibid., par. 63 (Walbridge\&Ziai, p.48).

${ }^{154}$ Ibid., par. 65 (Walbridge\&Ziai, p.49).
} 
intelectual ${ }^{155}$. O "repouso" é um termo para a ausência de movimento no que pode ser concebido para estar em movimento, e a ausência não é algo realizado em coisas concretas, mas é algo inteligível no intelecto. A contingência é também algo intelectual. Daí resulta que as privações negativas são todas elas construtos da razão. Também a substancialidade não é algo adicionado à corporeidade nas coisas concretas $^{156}$. Assim, todos os atributos podem ser divididos em duas classes ${ }^{157}$. A primeira é o atributo concreto, que também tem uma forma no intelecto - como o preto, o branco e o movimento. A segunda classe é o atributo cuja única existência é sua existência no intelecto e que não tem nenhuma existência em nenhuma coisa, exceto no intelecto - por exemplo, contingência, substancialidade, coloração e existência $^{158}$.

Assim, nesse juízo Suhrawardī reitera brevemente sua crítica ao conceito de definição e ataca de maneira sucinta a doutrina das categorias (makulā) que, com efeito, não aparecem como tais e que são também construtos intelectuais ${ }^{159}$. Segundo Suhrawardī, o método da definição não é adequado e tampouco a classificação dos conceitos, na medida em que não se pode predicar nada da quididade de uma coisa determinada.

\subsection{5) As contradições na doutrina de forma e matéria}

Os peripatéticos ensinaram que o corpo se compõe de hyle (matéria) e de forma, enquanto no ensinamento correto dos filósofos mais antigos ${ }^{160}$ se diz: o corpo é uma extensão, a qual se manifesta em três dimensões (comprimento, largura e profundidade $)^{161}$. A argumentação peripatética, segundo Suhrawardī, é incorreta. Primeiro:

o argumento de que as dimensões são acidentes devido à ocorrência de alteração do comprimento, largura e profundidade, como em uma vela, é uma asserção infundada. Mesmo que essa dimensão estendendo-se em várias

\footnotetext{
${ }^{155}$ Ibid., par. 66 (Walbridge\&Ziai, p.49).

${ }^{156}$ Ibid., par. 67 (Walbridge\&Ziai, p.49).

${ }^{157}$ Ibid., par. 68 (Walbridge\&Ziai, p.50).

${ }^{158}$ Ibid., par. 68 (Walbridge\&Ziai, p.50).

${ }^{159}$ Ibid., par. 71 (Walbridge\&Ziai, p.52).

${ }^{160}$ Ibid., par. 76 (Walbridge\&Ziai, p.).

${ }^{161}$ Ibid., par. 72 (Walbridge\&Ziai, p. 53).
} 
direções seja um acidente, não se segue que a dimensão em si é acidental ao corpo ou é um acidente; para a extensão que aumenta o comprimento, a largura diminui, por exemplo. Da mesma maneira, se aumentar a amplitude, o comprimento é reduzido; e certas partes, anteriormente não conectadas, agora estão separadas. Seu mover alternadamente em várias direções é concomitante do mesmo, e seu movimento particular em diferentes direções são alterações acidentais. O corpo não é senão a dimensão e as três extensões são a extensão em que os lados do corpo vão em direções diferentes.

Eles estão certos ao dizer que a conexão não admite a separação se se entende a conexão entre dois corpos. No entanto, se por conexão se entende dimensão, é impossível para uma dimensão não aceitar a separação; assim, usando a conexão no lugar de dimensão leva a erro, porque a ambiguidade do termo leva alguém a imaginar que o que significa é a conexão que é destruída pela separação. ${ }^{162}$

Assim, a extensão continua sendo sem nenhuma transformação, e é essencial aos próprios corpos, pois a essência deve permanecer inalterada. Por conseguinte, uma eventual modificação particular nas três dimensões ocorre sem com isso alterar a essência. Estabelecer uma diferença entre corpo e matéria é desnecessário, uma vez que o corpo, receptáculo ou fortaleza ${ }^{163}$, é uma dimensão em si mesma. Suhrawardī também critica a noção aristotélica de substância segunda ${ }^{164}$, que será melhor desenvolvida no terceiro tratado da segunda parte, que tratará sobre a física.

\footnotetext{
${ }^{162}$ Ibid., par. 73 (Walbridge\&Ziai, p.53).

${ }^{163}$ Como será demonstrado nos tratados da segunda parte da obra, o universo consiste em graus de luz e obscuridade (ausência de luz). Os corpos não são mais que obscuridade e obstrução que não permite que a luz entre neles. A matéria é um estado intermediário entre a luz e a obscuridade total. Isso explica o porquê de Suhrawardī haver emprestado do persa a palavra barzah para denominar "matéria". Barzah significa estado intermediário, espaço intermediário, limbo. É o limite que separa e une as luzes e os estados tenebrosos e, assim, esse universo se denomina barzah, o espaço limítrofe, isto é, a mediação entre essas duas realidades. Por essa razão traduziremos barzah por limítrofe. Dessa maneira, o mundo sensível é um mundo intermediário e serve de limite entre a luz e a obscuridade total, entre o mundo dos inteligíveis e o mundo da matéria "pura" (que não é passível de sensibilidade). Ou seja, barzah significa o mundo sensível, o mundo da matéria percebida e inteligida como tal. Nesse sentido, Suhrawardī entende barzah como matéria ou como corpo, na medida em que é receptível à luz e à obscuridade. Considerado em si mesmo, cada barzah é obscuro, mas pode ser iluminado e ao ser iluminado é percebido como algo tenebroso, e, portanto, se torna inteligido.

${ }_{164}$ Ibid., par. $72-76$ (Walbridge \& Ziai, pp.53-56).
} 
Da mesma maneira, o incorpóreo, na sua totalidade ${ }^{165}$, se compara, em igualdade, à extensão, tendo, por assim dizer, também uma determinada extensão. $\mathrm{O}$ que é particular se modifica sem levar prejuízo à sua quididade. O ensinamento peripatético contraria os dados físicos da compressão e da rarefação, que são, para Suhrawardī, a separação e a reunião das partes de um corpo, com o preenchimento de um corpo sutil entre essas partes ${ }^{166}$. Se se seguisse o ensinamento dos peripatéticos, se concluiria uma impermeabilidade do corpo, quando assim, o volume de um corpo aumentasse, enquanto outro corpo não perde o seu volume. As partes de um corpo, constata Suhrawardī, têm uma tendência a se separar. No entanto, quando são impedidos explodem tal obstáculo, por exemplo, uma água fervente em uma panela ou o ar quente dentro de uma jarra.

É surpreendente que eles [os peripatéticos] pensam que o calor destrói a forma da água e que a sua ausência é uma condição da existência da forma de água. Se é possível que a ausência de um acidente como uma condição da existência de uma substância e ser uma causa, por que eles não admitirão que um acidente pode ser uma causa ou condição de sua existência? O que é um constituinte da existência se não algo que tenha algum papel na existência das coisas? Eles admitem que o calor precipita a forma do ar que está em vias de ser. Tais erros resultam em parte usando termos ambiguamente - como "forma" e assim por diante - e, em parte, façam exceções arbitrárias para princípios gerais. ${ }^{167}$

Os peripatéticos se confundem quando se referem à doutrina de matéria e forma, entre as diversas manifestações irracionais e suas consequências. Uma não tem como existir sem a outra, observa Suhrawardī. Com isso, muitas vezes, a matéria põe a forma como sendo a causa.

\subsection{6) Refutação do átomo particular e do vácuo}

A seguir, Suhrawardī constata que uma confusão entre potência e ato se coloca dentro do ensino peripatético: o corpo seria composto de átomos inseparáveis. O corpo é em potência, infinitamente divisível; não é, em ato, infinitamente divisível.

\footnotetext{
${ }^{165}$ Ibid., par. 78 (Walbridge\&Ziai, p. 57).

${ }^{166}$ Ibid., par. 75 (Walbridge\&Ziai, p. 54).

${ }^{167}$ Ibid., par. 84 (Walbridge\&Ziai, p. 60).
} 
Entre os erros resultantes de confundir o potencial com o atual está este argumento: "Um corpo é divisível em partes indivisíveis na imaginação ou no intelecto. Se pudesse ser dividido infinitamente, o corpo e suas partes seriam iguais em dimensão, já que ambos seriam iguais em sua divisibilidade infinita. No entanto, a igualdade entre parte e o todo é um absurdo". Essas pessoas não percebem que a divisão não é realmente existente, mas é apenas potencial. ${ }^{168}$

Assim, conclui Suhrawardī, o átomo é um construto intelectual, assim como a indivisibilidade infinita de um corpo.

Da mesma maneira que o átomo, o espaço vazio, ou seja, o vácuo, não existe na realidade concreta, pois a característica do corpo é idêntica à sua extensão. $\mathrm{O}$ vácuo é puramente uma extensão, assim também o corpo, pois “o que engloba o corpo deve exceder o que é menor do que ele e assim ter comprimento, largura e profundidade que podem ser apontadas. Por conseguinte, deve ser um corpo". ${ }^{169}$

\subsection{7) Convergências e divergências com a escola peripatética sobre as doutrinas da imortalidade da alma e da unicidade do existencialmente necessário}

Suhrawardī repassa os argumentos peripatéticos sobre a imortalidade da alma e afirma que, se bem que compartilhe tal doutrina, os argumentos peripatéticos são inadequados e se invalidam ao se apoiarem em conceitos como causalidade e contingência.

Entre as falácias resultantes de alterar o significado de um termo técnico para responder a uma objeção consta o seguinte argumento: “A alma não tem a potencialidade de inexistência e a atualidade do perdurar, para ela ser realmente existente e unitária. Por conseguinte, ela não pode deixar de existir". Contra isso, se pode apresentar uma resposta, "Tu julgas que as inteligências separadas são contingentes e realmente existentes. No entanto, o que contingentemente é, contingentemente também não é. Portanto, sua existência tem o potencial de não perdurar" ${ }^{\text {"170 }}$.

\footnotetext{
${ }^{168}$ Ibid., par. 89 (Walbridge\&Ziai, p. 63).

${ }^{169}$ Ibid., par. 90 (Walbridge\&Ziai, p. 64)

${ }^{170}$ Ibid., par. 91 (Walbridge\&Ziai, p. 64).
} 
Os seguidores dos peripatéticos contestam: a alma não pode ser destruída, porque é simples. Ao contrário, se deve realçar o seguinte: os espíritos puros são contingentes. Por isso, então, podem perder a sua existência. O corpo não é a causa da existência da alma, e não é a causa da continuação de sua existência, porque a alma continua sua existência sem seu corpo ${ }^{171}$.

A seguir, Suhrawardī estabelece o seu acordo com os seguidores dos peripatéticos, no que se refere à unicidade do existencialmente necessário. No entanto, Suhrawardī aponta a argumentação peripatética como falha.

Outro entre os argumentos inúteis com o qual eles respondem às objeções formuladas é: "A unidade no existencialmente necessário é negativa, seu significado é que é indivisível; mas em outras coisas é afirmativa, a base do número. Uma vez que o número é existencial, então é sua base”. Para isso, uma possível resposta, "O existencialmente necessário também é descrito por essa unidade, que é a base do número, para dizermos que o eterno é o um, e seu segundo é a primeira inteligência, seu terceiro é isso e seu quarto é aquilo. Assim, descrevemos, pela unidade que é a base do número, para nós contarmos ele e as existências enumeradas juntamente. Tal especial defesa e equívoco são de nenhum uso. A verdade é que a unidade é um atributo intelectual e nada mais, como já dissemos" ${ }^{\text {172 }}$.

Se o existencialmente necessário é mencionado como algo que deveria ser afirmado como "um", isso não quer significar que o "um" lhe pertence com uma real inerência. Ademais, essa unicidade é algo puramente negativo, por ser a negação da diversidade e nada mais.

\subsection{8) Defesa de Suhrawardī da realidade dos símiles platônicos}

Uma conclusão falha dos peripatéticos se coloca em sua oposição aos símiles platônicos: os símiles significariam, segundo eles, coisas que existem apenas enquanto

\footnotetext{
${ }^{171}$ Suhrawardī modifica a argumentação sobre a imortalidade da alma ao sustentar a origem celeste da mesma e a miserabilidade de seu estado presente e, por consequência, se apresenta a busca de um caminho através do qual a alma (luz interior) escape de sua prisão material e de seu exílio e retorne à sua morada original, na qual encontra paz e felicidade, tema central do último tratado da última parte da obra.

${ }_{172}^{17 b i d ., ~ p a r . ~} 93$ (Walbridge\&Ziai, p. 65).
} 
extensão. Consequentemente, no mundo celestial, os símiles não poderiam existir sem uma extensão.

Algo marcante em todo esse tratado, e particularmente nesse ponto, é o que concerne ao estatuto dos símiles. Suhrawardī acusa os peripatéticos de duplicar a realidade tratando os conceitos gerais da lógica (al-i tibāāât al- ${ }^{c}$ aqliyya) como realidades se ajuntando inutilmente à realidade das coisas ${ }^{173}$. Ao fazer isso, no entanto, Suhrawardī não quer rejeitar a realidade dos universais $(k u l l \bar{l})$; com efeito, o autor distingue dois tipos de universais: aqueles que estão "antes da multiplicidade das coisas" (mā qabla l-kațra) e os que estão "depois" de tal multiplicidade ( $m \bar{a} b a^{c} d a l$ katra). É sobre a confusão entre esses dois tipos de universais que Suhrawardī acusa os peripatéticos quando os mesmos negam a substancialidade dos símiles platônicos. Em uma importante passagem do Livro da sabedoria da iluminação, apresenta-se o argumento segundo o qual a subsistência por si mesma de uma forma específica (humanidade, equinidade, etc.) é inconcebível pelo fato mesmo que não importa qual indivíduo participando da realidade (haqīqa) de tal forma requer um sujeito de inerência (hulūl); para denunciar isso como uma confusão do símile (mițāl) com aquilo que é o símile, Suhrawardī explica-se, assim, ao se endereçar aos seus adversários.

Não é verdade que tu admites que a forma [específica] da substância [individual] se atualiza no espírito enquanto acidente, e não chegarás tu a dizer que há para as coisas uma existência concreta e uma existência no intelecto? Ora, se é admissível que a realidade substancial se atualiza no espírito enquanto acidente, então se pode tanto admitir que as quididades (al-

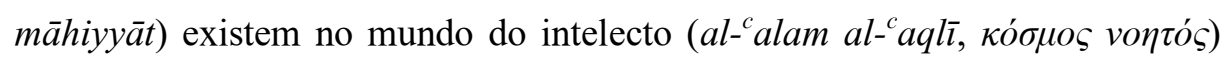
como coisas subsistentes por si mesmas, tendo elas nesse mundo ícones (așnām) que não subsistem por si mesmas. Estas são uma perfeição para outro, mas não têm a perfeição das quididades intelectuais, assim como as formas das quididades de substâncias externas ao intelecto ocorrem no intelecto e não são autossubsistentes - sendo uma perfeição ou um atributo do intelecto e não têm a independência e a autossubsistência que têm as quididades externas.

${ }^{173}$ WALBRIDGE, J. The Science of Mystic Lights: Quīṭb al-Dīn Širāzzì and the Illumianationist Tradition in Islamic Philosophy. Cambredige, Mass., 1992. 
Nesse caso, o que é verdadeiro de uma coisa não é necessariamente verdadeiro para o seu símile.

Em seguida, tu afirmas que a existência se aplica com um único significado para o existencialmente necessário e tudo mais. A existência é o existencialmente necessário em si mesmo, enquanto em outras a existência é acrescentada como acidente da quididade. Contra isso, pode-se argumentar da seguinte maneira: se a independência da existência do existencialmente necessário de uma quididade para que possa ser relacionado é devida à própria existência, então tudo seria assim. Se é devido a algo adicionado ao existencialmente necessário, então, contraria seus princípios e implicaria uma multiplicidade de aspectos no existencialmente necessário - que se demonstra ser um absurdo. Não pode ser porque o existencialmente necessário é incausado, por sua falta de necessidade de uma causa, pois é necessário e não contingente. A necessidade não pode ser interpretada como a negação de uma causa, pois é por causa de sua necessidade, que ela não tem necessidade de uma causa. Ademais, se sua necessidade foi adicionada à existência, o existencialmente necessário seria múltiplo, e o argumento seria a necessidade adicionada à existência - o que é um atributo do existente - perguntando se a necessidade seria posterior e concomitante do existente enquanto existente. Se assim for, o mesmo seria verdadeiro para todos os existentes; se não, a necessidade seria devida a uma causa. Se a necessidade é devida à própria existência, a dificuldade é óbvia e nos leva a dizer que se sua independência é devida à existência considerada em si mesma, teria que ser assim no caso de todas as coisas. ${ }^{174}$

Ou seja, é bem verdade que os símiles representam os espaços de existentes concretos na abstração do pensamento e são apenas imagens, o que não vale para os símiles platônicos. Suhrawardī se põe aqui do outro lado da caverna de Platão: invertendo a perspectiva, Suhrawardī considera os símiles como sendo "quididades" subsistentes por si mesmas no mundo inteligível - por isso, os demais filósofos póssuhrawardianos chamarão o seu sistema de doutrina da "presença da quididade" (așālat al-māhiyya, em oposição da doutrina da "presença da existência", al-wujūd). Como se verá depois, essas quididades são, com efeito, “os senhores, cujas espécies

${ }^{174}$ Ibid., par. 94 (Walbridge\&Ziai, pp. 66-67). 
são os ícones" (arbāb al-aṣnām al-naw $\left.{ }^{c} \bar{y} y a\right)^{175}$; os intelectos são indivíduos ( mutahașșișa) com estatuto de "universal" (kullī) no sentido de que os intelectos constituem o fundamento de suas existências ( $a s ̣ l)$, deles fluindo (fayyāó) as espécies, sem se confundir nem com as próprias espécies, as quais tem o estatuto de "universal

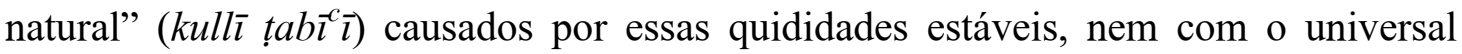
cujo conceito não impede a participação, isto é, aquele da lógica. São as entidades dominantes, arqueangélicas, pertencentes ao mundo das luzes separadas (al-anwār almujarrada) e jamais se encarnando e se manifestando no mundo material ${ }^{176}$.

\subsection{9) A doutrina iluminacionista da pluralidade de causas para uma coisa simples}

Uma causa pode se formar de muitas $\operatorname{partes}^{177}$, ou seja, uma coisa pode ter muitas causas, quando essas muitas partes formam uma unidade. Uma coisa, vista no seu particular, pode se manifestar com a propriedade de duas causas independentes. Com efeito, Suhrawardī postula que uma coisa particular não pode ter várias causas. "Se cada uma tivesse alguma influência sobre sua existência, então cada uma seria uma parte da causa e não uma causa completa. Se uma delas não tem influência, a causa seria a outra"178. Algo geral, por sua vez, pode ter diferentes causas. Por exemplo, "o calor pode ser necessitado por um corpo quente adjacente, por radiação e pelo movimento". 179

\subsubsection{0) Certos juízos correspondentes às percepções - os quais serão úteis na ciência das luzes}

Um dos princípios fundamentais da filosofia de Suhrawardī é que as leis que governam a vista e a visão (baṣar, ibșār), estão baseadas na mesma regra contendo três componentes essenciais: a luz que se automanifesta, o ato da contemplação (mušăhada) e o ato da iluminação (išrāq). A vista se manifesta como resultado do encontro do sujeito que vê um elemento luminoso, em um dado instante, quando um está frente a outro. A contemplação se produz da mesma maneira, mas o instrumento

\footnotetext{
${ }^{175}$ Ibid., par. 152-153 (Corbin, pp.137-140; Walbridge \& Ziai, p.100-102).

${ }^{176}$ Ibid., par. 169 (Corbin, p.153; Walbridge \& Ziai, p.109).

${ }^{177}$ Ibid., par. 96 (Walbridge\&Ziai, p. 67).

${ }^{178}$ Ibid., par. 98 (Walbridge\&Ziai, p. 68).

${ }^{179}$ Ibid., par. 98 (Walbridge\&Ziai, p. 68).
} 
não é mais o órgão da visão, mas o ato criativo da imaginação que opera no sujeito o encontro íntimo da luz imaterial que ilumina, quando já não há obstáculos entre o sujeito e a coisa, isto é, opacidade e obscuridade.

Se a visão se formasse de tal modo que o raio de visão alcançasse a coisa, assim não se poderia ver simultaneamente, o que está próximo ou distante ${ }^{180}$. Mais ainda, o "enxergar" seria apreender a imagem nos olhos, o que tornaria impossível ver coisas maiores do que os olhos ${ }^{181}$. Assim, a visão ótica se forma, de tal maneira, que a imagem flui do doador das formas e se une com o sentido disposto. O espelho simplesmente se confronta com uma coisa iluminada e tem a qualidade de um tipo de luz, que ilumina um espelho e, por meio do próprio espelho, ilumina a coisa que se coloca à frente dos órgãos da visão ${ }^{182}$. Pode-se provar experimentalmente que no espelho há uma dimensão de profundidade. Por exemplo, ao se aproximar o dedo do espelho, assim se aproxima dentro do espelho a imagem do dedo. Uma imagem acontece simplesmente ao se estar de frente às coisas. Assim, dentro da alma, acontece “uma iluminação presencial”, pois através dele a alma reconhece a coisa iluminada. Nesse sentido, "presencial" se chama o mesmo, porque foi criado dentro da alma, sem ser "impregnado" pelo exterior.

Assim, em sua consideração sobre a visão e ao criticar a teoria de "outros homens de ciência"183 (Aristóteles e os peripatéticos), Suhrawardīincorpora ao conceito de "apreensão intelectual" ou de "conhecimento presencial", elementos característicos de todo o pensamento iluminacionista, em que as visões ocorrem pela presença de luz ou de algo luminoso, tema que se estenderá detalhadamente no quinto tratado de sua metafísica. Esse método será conhecido depois pelos filósofos que seguiram Suhrawardī como "primazia da quididade" ou "primazia do concreto".

Suhrawardī usa sua doutrina sobre a ótica e a visão no que se refere ao seu estudo da acústica e da audição. É incerto que no momento do som no ar as "configurações" adquiram e apreendam os consoantes, etc., assim como ensinam os peripatéticos; porém, as configurações e os "limites" determinados das letras não

\footnotetext{
${ }^{180}$ Ibid., par. 101 (Walbridge\&Ziai, pp. 70-71).

${ }^{181}$ Ibid., par. 102 (Walbridge\&Ziai, p. 71).

${ }^{182}$ Ibid., par. 104 (Walbridge\&Ziai, p. 72).

${ }^{183}$ Ibid., par. 102 (Walbridge \& Ziai, p. 71).
} 
podem se manter de modo contínuo, porque são extremamente flexíveis, maleáveis. As configurações dentro das consoantes se confundem até o ouvido, não havendo mais como distinguir. O som não tem como ser definido, pois para cada qual que tem o sentido da audição o som é manifesto, mas, para aquele que não tem, ele continuará incompreensível. Esse processo da audição é incompreensível, postula Suhrawardī, sem que se pense que são resultantes de substâncias puramente espirituais, as quais provocam no ar o som. O som, conclui Suhrawardī, é uma coisa simples. A sua imagem do conhecimento dentro do intelecto se comporta da mesma maneira como aquilo que se percebe como exterior ${ }^{184}$. Suhrawardī reitera mais uma vez que

as simples sensações e experiências são todas sem partes e nada é mais manifesto do que elas. Por elas, seus compostos são conhecidos. A realidade do som não pode ser definida para alguém sem o sentido da audição, nem a luminosidade pode ser definida a alguém sem o sentido da visão. Por qualquer definição que pudesse ser definida, ele não compreenderia sua realidade. A sensação provocada por um sentido não teria qualquer proveito em definir as sensações de outro sentido em sua particularidade. Alguém com os sentidos da audição e da visão não tem necessidade de definições de luminosidade e de som. ${ }^{185}$

Essa primeira parte do Livro da sabedoria da iluminação serve de base e sustentáculo ao que será exposto na segunda parte, a sua metafísica. Suhrawardī opera uma desconstrução da lógica e da epistemologia aristotélicas. Essa parte está codificada em uma série de regras analítico-descritivas extraídas de suas principais críticas à doutrina aristotélica e cumpre o intento determinante para levar adiante seu projeto: a redefinição da teoria do conhecimento sobre a qual sustentará sua ciência das luzes. Deve-se lembrar que a sabedoria discursiva (hikma bahtīiyya) é um método de conhecimento, válido e insuficiente, e que representa uma atitude filosófica com método próprio associada com a tradição peripatética que critica. Com efeito, deve-se também destacar o que Suhrawardī afirma: não se trata de uma recusa categórica e

\footnotetext{
${ }^{184}$ Ibid., par. 105 (Walbridge \& Ziai, p. 74).

${ }^{185}$ Ibid., par. 105 (Walbridge \& Ziai, p. 74).
} 
definitiva do método peripatético, mas de sua reelaboração e, consequentemente, a incorporação ao seu sistema iluminativo, cujo momento culminante foi seu célebre diálogo com Aristóteles ${ }^{186}$.

A sabedoria intuitiva (hikma dawqīyya) é, assim, um novo método de conhecimento, ainda que não exclua os demais, ponto de partida para sustentar a ciência das luzes e objetivo fundamental de todo aquele que a pratica. Desse modo, fica evidente que nessa obra Suhrawardī opera a reconstrução integradora da filosofia aristotélica e das mais diversas sabedorias pré-aristotélicas, restaurando-as todas dentro de um prisma platônico. "Isso é o que se pretendia dizer aqui e, assim, a primeira parte é encerrada. Interminável louvor seja dado à luz das luzes!"187

\footnotetext{
${ }^{186} \mathrm{O}$ método da iluminação entendido como primeira premissa do conhecimento filosófico foi transmitido a Suhrawardī por Aristóteles (cf. al-Mašāric wa 'l-muțārahāt em SOHRAVARDÎ, op. cit., p. 484), que lhe apareceu em sonho e lhe informou que o conhecimento de si - que não é nem puramente discursivo nem puramente contemplativo - é o prelúdio a todo o conhecimento superior (cf. al-Talwīhāt em SOHRAVARDÎ, op. cit., p. 70 ss.). A ideia de uma convergência entre Platão e Aristóteles encontra um sólido apoio, para boa parte dos pensadores arabófonos, na Utúūiujiya (Teologia) do pseudo-Aristóteles sobre a soberania divina (fi'l-rubūbiyya). Isso já era anterior ao próprio aparecimento da filosofia árabe. O pensamento filosófico que os árabes encontraram era dominado pelo sincretismo neoplatônico representado, por excelência, pela famosa escola filosófica de Alexandria. Esta se caracterizou pela busca de coerência entre Platão e Aristóteles - ver sobre o aristotelismo corrente entre os neoplatônicos e a sua platonização em HADOT, Ilsetraut. Simplicius, Commentaire sur le Manuel d'Epictète (chapitres I à XXIX), éd. Et trad., Paris, CUF, 2001, pp. CLXVII-CLXX (VALLAT, Philippe. Farabi et l'École d'Alexandrie: Des premisses de la connaissance à la philosophie politique. Paris : Vrin, 2004, p. 37, nota 2). Assim, se poderá encontrar em Temístio alguém que interpreta Aristóteles recorrendo a Platão, Plotino e aos estoicos e considera Aristóteles uma introdução a Platão - ver PINÈS, Shlomo. "Some distinctive Metaphysical Conceptions in Themistius' Commentary on Book Lambda and Their Place in the History of Philosophy", Aristotle Werk und Wirkung, J. Wiesner (ed.), vol. 2. Berlim: De Gruyper, pp. 267-294; sobre o aristotelismo enquanto etapa ou sacrifício preparatório (protéleia) ao platonismo: HADOT, Pierre. "Les divisions des parties de la philosophie dans l'Antiquité", Museum Helveticum, 36 (4), pp. 201-223. (VALLAT, Philippe. op. cit. Paris : J. Vrin, 2004, p. 39, nota 5). Suhrawardī entende o "verdadeiro" Aristóteles como um "platônico"; na introdução ao seu Talwīhăt, Suhrawardī afirma que seu propósito é transmitir o conteúdo da doutrina do Primeiro Mestre (Aristóteles), sem levar em conta as interpretações correntes entre os peripatéticos. Suhrawardī ao discorrer sobre as categorias da lógica aristotélica, toma a liberdade de se afastar da doutrina comum, pois "as categorias não provêm do Primeiro Mestre, mas de um pitagórico chamado Arhūțās (Archytas)" (SOHRAWARDÎ, op. cit., I, p. 12).

${ }^{187}$ Suhrawardī, op. cit., par. 106 (Walbridge \& Ziai, p. 75).
} 


\section{CAPÍTULO III}

\section{A CONSTRUÇÃO DA CIÊNCIA DAS LUZES}

\section{Primeiro tratado: Sobre a luz e sua essência. Sobre a luz das luzes e o que flui dela por primeiro, em nove seções e regras - apresentação da metafísica de Suhrawardī}

Como Suhrawardī já fez na primeira parte de sua obra, ele estabelece aqui os elementos com os quais desenvolve e sustenta a sua metafísica por meio de três distinções fundamentais: luz e obscuridade, substância e estado, independência e dependência. As duas primeiras duplas estão relacionadas às classes dos existentes no universo e a terceira se refere à cadeia de causalidade, ou seja, com a sequência de luzes que começa e termina em uma luz sem causa e eterna: a luz das luzes (nūr alanwār).

Suhrawardī - ao contrário dos peripatéticos que iniciam a exposição de uma ciência com a delimitação e a definição de conceitos e não com a sua demonstração começa por introduzir rapidamente a apresentação e demonstração de luz:

Se há entre os existentes alguma coisa que não tem necessidade nem de que se a defina, nem de que se a explique, é o manifesto (zāhir). Ora, não há nada mais manifesto que a luz. Portanto, não há nada que seja mais que a luz, independente de qualquer definição ${ }^{188}$.

Isso porque, segundo o autor, a definição de algo se sustenta na experiência direta. Assim, "a luz é o que se manifesta em razão de sua própria realidade (haqīqa) e que, por si mesma, faz aparecer tudo o que é diferente dela mesma."189 Dessa maneira, Suhrawardī não busca demonstrar algo, a não ser apresentando uma explicação do conceito-chave da sua ciência das luzes, isto é, chamando a atenção para o manifesto (zâahir) e não para a manifestação. Como ponto de partida é significativo, pois é diferente da maneira corrente entre os filósofos árabes de iniciar suas respectivas metafísicas com termos como "existente”, “coisa", "necessário". Baseando-se menos

\footnotetext{
${ }^{188}$ Ibid., par. 107 (Corbin, p.97; Walbridge \& Ziai, p.76).

${ }^{189}$ Ibid., par. 117(Corbin, p.104; Walbridge \& Ziai, p.81).
} 
em tais conceitos e mais naquilo que se evidencia, Suhrawardī explicará a estrutura da realidade de acordo com o que se experimenta dela.

Uma vez apresentada a luz, o autor diferencia as luzes em autossuficientes e indigentes, segundo a sua própria terminologia ${ }^{190}$. Uma luz é autossuficiente em luminosidade quando "nem a identidade nem a perfeição de uma luz provém de outra", ao passo que é indigente quando "sua identidade e perfeição dependem de outra coisa que não seja ela mesma”. Assim, Suhrawardī decompõe as luzes em imateriais ou puras e acidentais ou eventuais segundo sua intensidade luminosa. Estas últimas, por fim, se decompõem nas que são independentes de receptáculo (maḥal), mas dependentes da obscuridade.

Os termos luz e luminescência são, para o autor, sinônimos, e obscuridade não é outra coisa que "a expressão para a ausência de luz." ${ }^{191}$ Dessa maneira, conclui Suhrawardī:

a supor que o mundo fosse vazio, ou que ele fosse uma esfera na qual não haveria nenhuma luz, o mundo seria tenebroso; a deficiência que exprime a escuridão lhe seria inerente, ela seria igual, nele, com a ausência da possibilidade da luz. Encontra-se assim fundado que tudo que não é luz nem luminescente é tenebroso. ${ }^{192}$

Divide-se assim a realidade:

1. luzes puras, imateriais, independentes e autossuficientes (anwār mujarrada, anwār al-mahd);

2. luzes acidentais, dependentes e indigentes;

3. substâncias corporais (al-jawāhir al-g்asīqa) que têm a obscuridade como verdadeira natureza;

4. obscuridade ou estados obscuros (hay'a zulmāniyya).

Como parte da estrutura ordenada de Suhrawardī, dentro desse esquema, o autor denomina barzah o limite, o istmo, o obstáculo ou a barreira que oculta e

\footnotetext{
${ }^{190}$ Ibid., par. 108 (Corbin, p.97; Walbridge \& Ziai, p.76).

${ }^{191}$ Ibid., par. 109 (Corbin, p.98; Walbridge \& Ziai, p.77).

192 Ibid., par. 109 (Corbin, p.98; Walbridge \& Ziai, p.77).
} 
evidencia simultaneamente o grau de luminescência dos seres, assim delimitando, apresentando e distinguindo um estado.

Os limítrofes, já limitados pelas obscuridades que lhes são próprias ${ }^{193}$, são dependentes, não de um estado luminoso ou de uma substância obscura, mas de uma luz imaterial ${ }^{194}$. Assim, fica evidente que, para Suhrawardī, a causa de toda a realidade é uma luz imaterial: "Uma vez que isso [a luz imaterial] doa à totalidade dos limítrofes sua luz e seu existir, tal luz deve ser viva e se conhecendo a si mesma, uma vez que é uma luz por si mesma"195, “[...] mesmo que acidental”"196. Suhrawardī pode, então, afirmar que exatamente a luz imaterial, a luz por si mesma, pode gerar o surgimento de outras luzes. Embora todas as coisas sejam causadas por luzes imateriais, nem todas as coisas são luzes imateriais nem mesmo luzes. Os corpos e os seus acidentes obscuros não são luzes. A luz é, portanto, o princípio de relação e de interconexão da realidade. A luz é, assim, o que há de mais manifesto. ${ }^{197}$

Com efeito, a luz e a obscuridade não são geradas - por igual - a partir da luz das luzes, pois causar luz não é o mesmo que causar obscuridade ${ }^{198}$. Se fosse assim, na luz das luzes haveria mescla tanto de luz quanto de escuridão, o que para o autor é um absurdo. Desse modo, a obscuridade mesma é o menor grau de irradiação da luz dependente da luz imaterial mais débil e com maior grau de dependência.

O sistema de Suhrawardī se caracteriza por uma ordem de causalidade na qual a aparição continua de algo dependente de algo maior que a si mesmo. Define-se essa relação em termos de dependência e independência, ou seja, uma luz imaterial sempre depende de outra maior em ordem. Para o autor, não pode haver uma ordem de luzes ordenadas em uma série infinita, visto que uma ordem simultânea deve ser finita. Assim, as luzes imateriais, as acidentais e os limítrofes devem culminar em uma luz, além da qual não haja outra luz. Essa luz é a luz eterna, a luz sagrada, a luz dominante,

\footnotetext{
${ }^{193}$ Ver nota 163.

${ }^{194}$ Ibid., par. 111 (Corbin, p.100; Walbridge \& Ziai, p.77).

195 Ibid., par. 128(Corbin, p.111; Walbridge \& Ziai, p.86).

${ }^{196}$ Ibid., par. 110 (Corbin, p.99; Walbridge \& Ziai, p.78).

${ }^{197}$ Ibid., par. 107 (Corbin, p.97; Walbridge \& Ziai, p.76).

${ }^{198}$ Ibid., par. 135 (Corbin, p.117; Walbridge \& Ziai, p.90).
} 
a luz absoluta, a pura luminescência, a luminescência independente, a luz das luzes ${ }^{199}$, aquela que tudo rege e à qual nada se opõe nem domina. Da luz das luzes deriva todo reino, poder e perfeição, sendo ela o primeiro existente, o existente por excelência, o necessário $(w \bar{a} j \bar{l} b)$ que não tem atributos. Essa luz é una, e tudo o que não for ela é dependente dela. Nada pode se associar a ela ou lhe acrescentar algo, pois não tem atributo nenhum, seja em estado luminoso ou obscuro ${ }^{200}$. Se assim não fosse, prossegue Suhrawardī, tal luz não seria pura e um acidente luminoso só pertence àquele cuja luz se incrementa ou varia em seu grau de intensidade ${ }^{201}$.

A importância da luz em Suhrawardī se estabelece em outro aspecto de sua metafísica, que o autor denominou como regra iluminacionista:

Primeira regra geral: A luz imaterial não pode ser passível de uma indicação sensível.

Desde agora que tu sabes que toda luz que se pode mostrar é uma luz acidental; se, portanto, existir uma luz pura, não se pode mostrá-la; ela não pode residir num corpo e ela não tem absolutamente nenhuma dimensão espacial.

Segunda regra geral: O que é luz por si mesma é uma luz imaterial.

A luz acidental não é uma luz por si só, uma vez que ela existe por outra; ela só é luz, portanto, por outro que não ela. Mas a luz pura imaterial é uma luz por si só. Toda luz que é uma luz por si mesma é uma luz pura. ${ }^{202}$

Se há uma luz pura, esta é diferente da luz visível; disso se conclui que não se pode apreender a essência da luz pura e imaterial nem por meio de uma imagem nem por qualquer atributo, pois sua essência é autoevidencia. O conhecimento desse tipo de luz é direto, intuitivo e presencial.

Como se pode ver em sua lógica, Suhrawardī defende que a definição não conduz a um conhecimento verdadeiro e essencial. Assim, defende que a percepção

\footnotetext{
${ }^{199}$ Luz das luzes (nūr al-'anwār), no islã, é um dos 99 nomes de Deus.

${ }^{200}$ Ibid., par. 129 (Corbin, pp.112-113; Walbridge \& Ziai, p.87).

${ }^{201}$ Ibid., par. 132-134 (Corbin, pp.114-115; Walbridge \& Ziai, p.88).

${ }^{202}$ Ibid., par. 112-113 (Corbin, p.101; Walbridge \& Ziai, p.79).
} 
$(i d r a \bar{k})$ - entendida enquanto apreensão - é o ato de conhecimento em si mesmo de algo que se desconhece ou que está oculto ( $a l-\check{s} a y$ ' $a l-\dot{g} \bar{a}$ 'ib), ocorrendo quando o símile (mital) de sua realidade (haqīqa) é obtido por aquele que busca conhecer. O termo $i d r a \bar{k} k$ indica vários níveis de conhecimento, desde a apreensão sensorial (idrāk $h \bar{\imath} s s \bar{\imath}$ ), passando pela intelectual (idrāk $\left.{ }^{c} a q l \bar{l}\right)$ e pela contemplação (mušāhada), até chegar ao saborear da sabedoria $(\underline{d} a w q)$ - traduzido, em alguns casos, como intuição, ou seja, a aquisição direta do conhecimento suprassensível, sem a mediação de uma experiência ou de um pensamento.

Para Suhrawardī, conhecer algo significa apreender a sua verdadeira realidade, estabelecendo-se uma relação iluminativa (iḍāfa išrāqiyya), ou seja, um conhecimento baseado na iluminação e na presença que se vive nesse instante ('ān) sem duração, e anterior a todo conhecimento formal. Por isso, Suhrawardī afirma que toda luz visível, material, é acidental e se evidencia a partir de uma iluminação dependente com nível descendente, que é obscuridade em si mesma. Por conseguinte, a luz não é um raio que intervém espacialmente e ilumina algo determinado e que desse algo se reflete. Suhrawardī pode, então, sustentar que não há raios intervenientes ${ }^{203}$, ou seja, não há transferência de um acidente ou divisão da substância da luz. O raio $\left(\check{s}_{\bar{l}}^{c} \bar{a}^{c}\right)$ não é uma linha de luz que emerge dessa luz, senão a iluminação da superfície iluminada. Suhrawardī se sente seguro em criticar os peripatéticos, pois os mesmos

declaram que o princípio de toda coisa não é nada mais do que a pura existência. Ora, quando se investiga sobre a matéria, tal qual prega sua doutrina, o resultado só faz reconduzir precisamente à pura existência, uma vez que a particularização concreta, como a chamamos precedentemente, só tem lugar graças às qualidades substanciais. Ora, não existe nada que seja a quididade em si mesma em estado absoluto; não, isso que é dado positivamente, é uma particularização, de sorte que se diz "é uma quididade" ou "é um existente". [... $]^{204}$

${ }^{203}$ Ibid., par. 146 (Corbin, pp.129-130; Walbridge \& Ziai, p.97).
${ }^{204}$ Ibid., par. 120 (Corbin, pp.107-108; Walbridge \& Ziai, p.83). 
Suhrawardī passa, então, à conclusão de que apenas o que tem uma existência simples, ou seja, a luz, pode ser a base da realidade de todo existente:

encontra-se estabelecido que o que conhece a si mesmo é uma luz por si e, vice-versa. No caso da luz acidental, se se supõe a mesma em estado imaterial, ela é igualmente revelada em si para si mesma. Isso que, portanto, constitui a realidade, é a essência do existente, que em si se revela a si. Sua própria realidade é a realidade da luz, posta como separada [da matéria]. O sujeito é aqui o predicado (al-huwa huwa), havendo reciprocidade perfeita. ${ }^{205}$

A realidade da luz e o manifesto pela luz são a mesma coisa, sendo sua atividade específica a de gerar outras luzes que, em suma, é, para o autor, a própria vida das luzes $^{206}$.

Com efeito, as luzes variam em sua realidade por perfeição e carência, ou seja, por seus graus de intensidade (šidda, ištidād) luminosa e por entidades externas ou acidentais. Assim, aquilo que não é luz não participa da realidade luminosa, mesmo sendo parte dela ${ }^{207}$. Consequentemente, as classes de luz, suas diferenças e atividades serão os temas que Suhrawardī abordará a seguir de forma ampla. Isso, ele o faz ancorado em três princípios: o criador de tudo o que existe é luz; a existência é um construto intelectual; o manifesto se autoconhece por si mesmo através da experiência direta e iluminativa.

Como no reino do visível o Sol alumia com seu clarão, assim a luz das luzes confere a todos os existentes a essência e o conhecimento. Essa luz está para além dos existentes, pois não depende de nada, a não ser dela mesma, sendo autossuficiente. Suhrawardī pode explicar, dessa maneira, que há uma prova da realidade da luz das luzes, a partir da causalidade e da experiência direta do conhecimento. Assim, chegase à geração procedente do uno ao múltiplo, dentro desse esquema iluminativo, integrando o idêntico e o diverso no cosmos, como modo de participação do existente na existência.

\footnotetext{
${ }^{205}$ Ibid., par. 120 (Corbin, pp.107-108; Walbridge \& Ziai, p.83).

${ }^{206}$ Ibid., par. 121 (Corbin, p.108; Walbridge \& Ziai, p.84).

${ }^{207}$ Ibid., par. 125-127 (Corbin, pp.110-111; Walbridge \& Ziai, pp.85-86).
} 


\section{Segundo tratado: Sobre a ordem da existência, em catorze sessões - a cosmologia de Suhrawardī}

Se há uma unicidade primordial e se dessa unicidade advém tudo o que existe, como o universo - que é múltiplo - passou a existir? Em sua metafísica, Suhrawardī sustenta sua resposta no conceito de luz, auxiliado por certos axiomas racionais que ele mesmo empresta dos peripatéticos. O mais importante desses princípios é o de razão suficiente ( $q \bar{a}$ 'idat al-tarjīh murāji). Outros utilizados são o da mais nobre contingência ( qâa'idat al-īmkān al-'ašraf) e o da impossibilidade de uma ordem infinita. O princípio da razão suficiente sustenta que nada é sem que haja uma razão para que seja, isto é, para que algo seja ou aconteça é necessário que haja uma causa superior. Se uma entidade de ordem elevada de existência é a causa das entidades menores, deve haver dois aspectos distintivos para explicar a existência separada de ambas as coisas. Ademais, uma entidade menor não pode ser causa da existência de uma maior, pois se houvesse causa suficiente para sua superioridade incorrer-se-ia em um absurdo.

Grosso modo, os contemporâneos de Suhrawardī, no que se refere à infinitude, só permitiram infinitudes parciais ou desordenadas, princípio que leva a Aristóteles. Qualquer sequência na qual haja uma ordem de qualquer classe e cujos individuais aparecem juntos deve ser necessariamente finita. Assim, por exemplo, o tempo pode ser infinito pelo fato de que todos os seus momentos não aparecem simultaneamente; do mesmo modo, o número de individuais no mundo da imagem pode ser infinito porque não podem ser numerados simultaneamente. Com efeito, o número de níveis de existência deve ser finito. Já que Suhrawardī compartilha a mesma conclusão dos peripatéticos, isto é, a conclusão de que a entidade mais alta é a mais simples, é evidente a razão pela qual, para Suhrawardī, o cosmos tem uma estrutura piramidal de níveis de existência com graduação decrescente complexa que vai desde a unicidade simples do nível mais alto até a multiplicidade caótica do mundo físico. Não obstante, não se pode postular que a cosmologia de Suhrawardī seja idêntica à dos peripatéticos; nesse domínio também, Suhrawardī estabelece suas diferenças. Suhrawardī identifica a luz - e não a existência - como o sujeito de sua ciência. Mais do que isso: não se trata de mera substituição da existência pela luz; a 
luz e a doutrina dela resultante estão muito distantes da existência e da ciência daí resultante. Com o desenvolvimento do tratado, Suhrawardī se separa cada vez mais de sua comunhão com os peripatéticos, estabelecendo importantes diferenças estruturais, sendo rigoroso e claro ao identificar certos princípios, regras, método e afirmações que denomina iluminativas.

Suhrawardī é específico ao aplicar suas principais teses em sua cosmologia ${ }^{208}$ : o criador de tudo o que existe é uma luz (1); os intelectos imateriais são luzes e ultrapassam o número de dez (2); cada espécie tem seu símile platônico, que é uma luz imaterial da ordem horizontal.

A base da existenciação no cosmos é a luz imaterial, uma luz por si mesma e para si que se evidencia em si mesma e que gera, a partir de si, outras luzes. Depois de afirmar que a luz é a única realidade, Suhrawardī conclui que, pelo princípio de razão suficiente, que da luz das luzes só pode haver um único efeito, que é uma luz ${ }^{209}$ jamais escuridão, pois do contrário haveria mais de um aspecto na luz das luzes e a luz excelsa seria múltipla, o que é absurdo. Assim, a luz primeira emitida é denominada por Suhrawardī como "luz poderosa", a luz conhecida pelos antigos persas como Bahman (Vohu Manah) ${ }^{210}$, dependente e débil com relação à luz das luzes e ponto de partida do processo multiplicador descendente. É uma luz una que conhece a si mesma e a causa de sua geração (șudūr) ou emissão (ḥuṣūl). Em outras palavras, pode-se dizer, a título de resumo, que de uma unidade primeira provém uma unidade derivada, e desta - jamais daquela - procede a multiplicidade, visto que por ser mais débil em sua essência é também em seus atos. A geração de uma luz com tais características não ocorre por um ato de separação, já que separação e união são propriedades específicas dos corpos - não das luzes. A luz das luzes, dotada de absoluta liberdade, atua como vontade pura e amor (maḩabba). A natureza da luz das luzes é derramar, transbordar, fazer fluir. Ama, transborda amor, e por amar, dela flui amor. É generosa e não espera nada. Sua única atividade é sua autocontemplação e amar a si própria. Nesse transbordamento, emite outra luz, mais próxima a ela, capaz de recebê-la e ao mesmo tempo de contemplá-la, estabelecendo-se assim um vínculo de amor, paradigmático e

\footnotetext{
${ }^{208}$ Ibid., par. 165 (Corbin, p.150; Walbridge \& Ziai, p.107).

${ }^{209}$ Ibid., par. 136 (Corbin, p.118; Walbridge \& Ziai, p.91).

${ }^{210}$ Ibid., par. 138 (Corbin, p.120; Walbridge \& Ziai, p.92).
} 
perfeito, entre amado e amante, entre a luz das luzes e a luz próxima, como desígnio cognoscitivo da luz das luzes. Entre elas, entretanto, há um véu (hijāb), já que a relação é a de maior capacidade de iluminação.

A distinção luminosa por duplas, afirmada por Suhrawardī, em independente e dependente, necessária e contingente, pobre e rica, fraca e poderosa, se principia na luz próxima. Esta é independente e dependente ao mesmo tempo e, por isso, não pode gerar apenas luz - se assim fosse, tudo seria luz -, mas apenas uma luz imaterial, luminosíssima, e uma barreira, a maior de todas, a que tudo abarca, o primeiro grande limítrofe. Este, como todo limítrofe, funciona como uma sombra de sua mesma obscuridade - não há obscuridade entre a luz das luzes e a luz próxima, há apenas um véu, que permite a transparência ${ }^{211}$. A relação estabelecida, então, é a de uma luz menor que é sempre dominada por uma maior e, quando as luzes multiplicam-se, repete-se esse modelo em uma ordem perfeita.

Pode-se dizer, assim, que o cosmos está ordenado, para Suhrawardī, em uma ordem eterna de amor e de domínio ${ }^{212}$. A luz que se evidencia - em última análise, como emissão da luz das luzes - nas luzes imateriais é um esplendor ou irradiação que se faz cada vez mais fraca na medida em que avança o processo multiplicador descendente, ao qual Suhrawardī denomina de luz propícia (nūr sānih) ou o augúrio que chega. É uma luz acidental ou acidente luminoso que ilumina outra luz imaterial, pois há dois tipos de luzes acidentais: há as que advêm aos corpos materiais e há as que advêm às luzes imateriais. ${ }^{213}$

Assim, da luz próxima resulta um limítrofe e uma luz imaterial e, dessa luz, se gera outra luz imaterial e outro limítrofe. Essa sucessão continua até a nona esfera e o mundo elemental deve ser finita, pois a série cessa quando uma luz não resulta em nenhuma outra luz imaterial. Mas as luzes dominantes (anwār al-qāhira), imateriais e livres de conexão com os limítrofes, são mais de nove, dez, vinte, cem ou duzentas ou mil. Alguma coisa entre elas causa limítrofes dependentes e, as que são independentes

\footnotetext{
${ }^{211}$ Ibid., par. 143 (Corbin, p.128; Walbridge \& Ziai, pp.95-96).

${ }^{212}$ Ibid., par. 147-148 (Corbin, pp.130-132; Walbridge \& Ziai, p.98).

${ }^{213}$ Ibid., par. 149 (Corbin, pp.132-133; Walbridge \& Ziai, p.98).
} 
e individuais são menores em número que as estrelas que estão ordenadas por classe. $^{214}$

Uma segunda luz se gera da luz próxima e, da segunda uma terceira, desta uma quarta e assim sucessivamente. Cada uma delas contempla a luz das luzes e, também, a luz se reflete de uma a uma. Cada uma alumia a que segue em menor classe e hierarquia e a luz amante recebe a luz propícia, esplendor e augúrio da luz das luzes. Assim, a luz segunda recebe irradiação da luz das luzes de maneira dupla: pela própria luz das luzes, sem intermediários, e através da luz próxima. A luz terceira recebe quatro vezes: os dois reflexos de sua luz superior imediata, a da luz das luzes sem mediação e a da luz próxima. A quarta recebe oito vezes: os quatro reflexos de sua anterior superior, os dois do segundo, o da luz próxima e o da luz das luzes sem intermediários. Produz-se assim um efeito duplo e duplicável, de mesma classe e número $^{215}$. As luzes descendem gradualmente segundo seu grau de intensidade e de acordo com sua capacidade de contemplação. Essas são as luzes excelsas que geram outras luzes individuais em virtude da combinação de seus aspectos independentes, dependentes, dominantes, submissos, amorosos e contemplativos. Pode-se, dessa maneira, afirmar que a atividade mesma das luzes consiste na correspondência e na proporcionalidade do descenso de seus diferentes aspectos ${ }^{216}$. Essa atividade dá lugar às estrelas fixas e às suas esferas, sobretudo por meio das luzes amantes, mesmo que débeis por serem dependentes. Tal interconexão entre os aspectos de independência, dominação e amor e a correspondência entre os raios intensos e perfeitos e as outras luzes dominantes, dão lugar aos símiles celestes das espécies e aos elementos compostos e a tudo o que há debaixo das estrelas fixas ${ }^{217}$.

A luz próxima não é uma realidade débil, mas plena e fecunda, por cuja presença outro ser ou outra luz pode participar da luz das luzes. Suhrawardī fundamenta assim sua concepção ordenada do cosmos em que o superior é mais pleno e funda tudo o que é dependente dele.

\footnotetext{
${ }^{214}$ Ibid., par. 150-151 (Corbin, pp.133-136; Walbridge \& Ziai, pp.99-100).

${ }^{215}$ Ibid., par. 151 (Corbin, pp.134-137; Walbridge \& Ziai, pp.99-100).

${ }^{216}$ Ibid., par. 152 (Corbin, pp.137-138; Walbridge \& Ziai, p.101).

${ }^{217}$ Ibid., par. 152 (Corbin, pp.138-139; Walbridge \& Ziai, p.101).
} 
Suhrawardī utiliza o princípio da nobre contingência para explicar que a existência das espécies luminosas imateriais não é produto do acaso, e que tem uma causa superior $^{218}$. Como sua origem é uma luz dominante, os símiles também estão sujeitos às classes de amor, domínio e moderação ${ }^{219}$. Suhrawardī considera a ordem de luzes em duas direções, a saber: a vertical $(t \bar{u} l \vec{\imath})$ e horizontal $\left({ }^{c} \operatorname{ard} \hat{\imath}\right)$. Domina a ordem vertical a luz próxima, razão de ser das luzes que se seguem a ela, e que recebem a irradiação e o brilho da luz das luzes por seu intermédio. Essa irradiação e esse brilho são transmitidos a cada membro da ordem vertical através das luzes imateriais denominadas por Suhrawardī luzes vitoriais (anwār al-qāhira). Esta ordem é chamada também de mundo das mães ( ${ }^{c}$ ālam al-ummahāt) ${ }^{220}$ pois é daí que se gera tudo o que compõe o cosmos. Cada luz tem um limítrofe entre suas luminosidades, da de cima à de baixo, que atua como um véu ou transparência pela qual simultaneamente oculta e revela a luz da ordem superior.

Do aspecto masculino, isto é, de suas funções dominante e contemplativa, se gera a ordem horizontal de luzes que correspondem ao mundo dos símiles platônicos $^{221}$. Os membros dessa ordem não se originam um ao outro como na ordem precedente, mas se encontram um ao lado do outro ${ }^{222}$. Nessa cosmologia é inconcebível que as luzes dominantes de igual ordem se produzam simultaneamente a partir da luz das luzes; por isso deve haver luzes intermediárias ordenadas de maneira vertical, que não podem ser símile de tal ordenamento. Suhrawardī não limita o número de luzes, como já foi dito acima, a um número específico, como fizeram os peripatéticos com relação às inteligências cósmicas. Efetivamente, Suhrawardī critica seus predecessores por haverem limitado essa hierarquia intelectiva. Para ele, o número de luzes não é igual ao número de céus da astronomia ptolomaica, mas comparável com o número de estrelas fixas, ou seja, inumerável. Pode-se afirmar então que

\footnotetext{
${ }^{218}$ Ibid., par. 153 (Corbin, pp.139-140; Walbridge \& Ziai, p.101) e par. 164 (Corbin, p.149; Walbridge \& Ziai, p.107).

${ }^{219}$ Ibid., par. 153 (Corbin, p.139; Walbridge \& Ziai, p.101).

${ }^{220}$ Ibid., par. 183 (Corbin, p.170; Walbridge \& Ziai, p.119).

${ }^{221}$ Ibid., par. 173 (Corbin, pp.156-157; Walbridge \& Ziai, pp.111-112).

${ }^{222}$ Ibid., par. 154 (Corbin, p.140; Walbridge \& Ziai, p.102).
} 
o autor das presentes linhas foi ele mesmo um vigoroso defensor da doutrina dos peripatéticos quando tal doutrina nega tais realidades, pois ele provou por ela uma forte inclinação. E ele haveria de perseverar nessa via, se não houvesse visto a prova de seu Senhor (burhan rabbi-hi).

Alguém que não dá crédito a esta atestação, e a quem esta prova não é suficiente, que ele empreenda os exercícios espirituais (riyādat) e que ele se coloque na escola dos mestres em contemplação (asḩāb al-mušăhada). Talvez, então, lhe chegue o êxtase, a visão da luz que se infunde no mundo do Jabarūt, e verá os anjos do Malakūt e as luzes que contemplaram Hermes e Platão, os clarões celestes, princípios da luz de glória. É delas que nos informa Zoroastro. É em direção delas que um êxtase arrebata o soberano verídico, o bem-aventurado Kay Hosraw, que obteve a visão-direta.

Os sábios da Pérsia são unânimes sobre este ponto, se bem que segundo eles, a água tem um anjo [um "senhor do ícone"] no Malakūt; eles o chamaram de "Hordād". Há o das plantas, chamado por eles de "Murdād"; e o do fogo, ao qual eles chamavam de "Urdibihišt".

E são essas mesmas as luzes a que Empédocles fizera alusão e vários outros além dele. $^{223}$

Os argumentos de Suhrawardī com relação aos símiles platônicos têm três aspectos: pode-se ter provas de sua realidade por meio da experiência presencial-iluminativa; os argumentos peripatéticos não são sólidos; e, por fim, sua realidade pode ser deduzida a partir do conhecimento das propriedades das luzes imateriais, ordenadas horizontalmente.

Suhrawardī se refere aos símiles platônicos chamando-os de símiles celestes das espécies, utilizando o termo "senhor dos ícones" (arbāb al-aṣnām) e "senhor do talismã" (sāhib al țilsim). São reflexos, ícones (șanam), representações espirituais de realidades materiais, já que cada um domina sobre alguma espécie em particular para a qual é o símile celeste. Por exemplo, Hūrahš (símile do sol), talismã de Šarir, é uma luz de grande clarão, o fazedor do dia, o senhor do céu, a ser venerado pelos

${ }^{223}$ Ibid., par. 166 (Corbin, p.151; Walbridge \& Ziai, p.108). 
iluminacionistas e por sua tradição ${ }^{224}$. Não é maior que os planetas por magnitude e tampouco por proximidade, mas por intensidade. Suhrawardī cita outros símiles: o da água chama Hordād, o dos minerais, Šahriwar, o das plantas Murdād e o do fogo, Urdibihišt.

Para Suhrawardī, o defeito dos peripatéticos consiste em assumir que uma coisa e seu reflexo são a mesma coisa; o autor, por sua vez, sustenta que a imagem não é necessariamente igual ao que se vê através da impressão ocular ${ }^{225}$. Assim, "a forma de cada coisa no mundo elemental será encontrada na esfera exatamente como se encontra aqui, em todos os seus estados"226. Está aqui uma correlação de sua crítica aos "construtos intelectuais", que Suhrawardī desenvolveu na primeira parte de sua obra. Assim, a realidade dos símiles é mais forte que toda realidade, pois o mundo material perece e os símiles permanecem. $\mathrm{O}$ mundo material é pesado e tenebroso e o mundo dos símiles é o mundo autêntico de luz, apreendida pela experiência contemplativa.

Dando prosseguimento à discussão sobre os símiles, Suhrawardī precisa melhor sobre as luzes imateriais, já que ambos se dividem em duas classes, a saber: dominantes (qawāhir), sem relação e sem conexão com os limítrofes e que incluem as luzes excelsas (al- $\left.{ }^{c} a l \bar{u} n\right)$ e as luzes dominantes formais, isto é, os próprios símiles (1); e as regentes (anwār-mudabbira) que são geradas pelos símiles (2).

Tal especificação é importante, embora pareça uma repetição, visto que Suhrawardī a utilizará para explicar que, a partir do aspecto feminino da ordem horizontal de luzes, amor e receptividade, geram-se as estrelas fixas e, por meio destas, o céu astronômico. Os céus visíveis são assim uma materialização e uma expressão das realidades luminosas. Por isso as esferas, corpos vivos, não são produtos de luzes dominantes, senão da luz regente (nūr isfahbād), luz imaterial que é considerada por Suhrawardī como alma das esferas ${ }^{227}$. Há um nível intermédio que atua como vice-regente das espécies, nome que também é dado às luzes que governam

\footnotetext{
${ }^{224}$ Ibid., par. 158-159 (Corbin, p.144; Walbridge \& Ziai, p.104).

${ }^{225}$ Ibid., par. 246 (Corbin, pp.214-215; Walbridge \& Ziai, p.149).

${ }^{226}$ Ibid., par. 260 (Corbin, p.222; Walbridge \& Ziai, p.155).

${ }^{227}$ Ibid., par. 155 (Corbin, pp.141-142; Walbridge \& Ziai, pp.102-103).
} 
a alma humana. Movem o céu através do amor e são as guardiãs de todas as criaturas da terra. No caso do homem, há uma luz senhorial no centro de cada alma que governa cada uma das atividades humanas. Como espécie em sua totalidade, é Gabriel quem é considerado o símile da humanidade ( $r a b b$ al-nāw' al insānñ) que Suhrawardī identifica com o Espírito Santo, doador do conhecimento $\left({ }^{c} i l m\right)$ e a inteligência ativa.

Nesse sistema, as estrelas são a sombra de uma ordem inteligível: a sombra de uma ordem horizontal de luzes, ou seja, o resultado da interação dos aspectos de dependência dos raios das luzes. A demonstração da causa do movimento das esferas ilustra a relação entre a ciência das luzes e o aristotelismo. Utiliza princípios peripatéticos da física para provar, por eliminação, que há algo que move as estrelas, tendo que ser algo vivente. Por isso, assim como as luzes das almas dos homens e dos animais, as luzes das almas das esferas fluem de uma luz senhorial.

De acordo com o princípio de razão suficiente, tudo possui uma causa para a sua existência e, de acordo com a ciência das luzes, a causa última é a luz imaterial, geradora de todos os eventos sublunares e, também, do movimento das esferas. O nível mais baixo da ordem vertical das luzes, mais baixo em hierarquia que as luzes que causam as esferas, são luzes que causam os elementos ${ }^{228}$; as causas formais dos corpos são produtos da ordem das luzes horizontais, os símiles platônicos. Diferentemente da ordem vertical - em que a distinção se dá pela intensidade de luminescência -, as luzes horizontais variam em luminosidade e em acidentes luminosos e obscuros. Por isso as espécies que controlam podem ter uma hierarquia diferente ou igual. Diferentemente da hierarquia das luzes, os senhores de cada espécie explicam a presença ou a ausência das luzes dominantes, da alma e do espírito animal. Nas espécies mais elevadas - plantas, animais e seres humanos - a natureza da luz está relativamente exaltada e a capacidade de constituição requer a mediação de outra luz, a alma individual, para conduzir o ser humano. Nas espécies inanimadas, por sua vez, a luz é de tal forma débil que se aproxima da condição de luz acidental e a capacidade do corpo é tão limitada que não é possível haver uma luz dominante como mediadora. Desse modo, Suhrawardī consegue explicar como as luzes imateriais causam os corpos materiais: a ordem vertical menor origina os elementos, origem dos corpos. A ordem

${ }^{228}$ Ibid., par. 173 (Corbin, pp.156-157; Walbridge \& Ziai, pp.111-112). 
horizontal de luzes imateriais é a causa formal de suas respectivas espécies. Os movimentos das esferas, causados pelas relações acidentais entre as luzes imateriais são a causa eficiente dos corpos e de seus acidentes.

Então, as luzes dominantes possuem dois aspectos: a obscuridade e a dependência, de um lado, e, por outro lado, a independência e a luminosidade. Por conseguinte, para Suhrawardī, os efeitos devem ser ordenados da seguinte maneira ${ }^{229}$ : uma luz em que predomina o domínio (1); uma luz em que predomina o amor (2); uma substância obscura em que predomina o domínio (3); uma substância obscura em que predomina o amor (4); substâncias obscuras e não luminosas em que predomina o domínio (5); e substâncias obscuras em que predominam o amor e a humildade (6). Com relação ao seu efeito, cada causa luminosa possui amor e domínio, cuja companhia é a humildade. Por isso, a existência procede por pares complementares divididos em luz-obscuridade e amor-domínio, segundo citação corânica, "de cada coisa, criamos um casal, para meditardes" (LI, 49).

O Sol - a partir de Platão, engendrado por analogia a si mesmo pelo sumo bem $^{230}$ - é o símbolo perfeito de um verdadeiro culto astral: é "a teurgia (țilsam) de Šahrīr, luz de clarão poderoso, autor do dia, príncipe do céu, a quem a tradição iluminativa (sunnat al-išrāq) impõe render culto."231

Suhrawardī finaliza este segundo tratado do Livro da sabedoria da iluminação ratificando que, no mundo de pura luz - sem nenhuma dimensão - todo elevado em grau causal está mais próximo daquele em que é menor a causa de sua intensidade ${ }^{232}$. A luz das luzes é o agente que domina através de seus intermediários, a causa de sua atividade, origem de toda geração, pois "em cada dia, Ele executa uma obra nova" (Alcorão LV, 29). Ao afirmar que há luzes dominantes, que o criador de todas as coisas é luz, que os símiles estão entre as luzes, Suhrawardī se apoia na tradição que, para ele, sempre sustentou essa doutrina: Platão, Sócrates, Agatodeimon e Empédocles, além dos sábios persas.

\footnotetext{
${ }^{229}$ Ibid., par. 156 (Corbin, pp.142-143; Walbridge \& Ziai, p.103).

${ }^{230}$ República 508a-509b; cf. PLOTINO. Eneadas I, 6, 9.

${ }^{231}$ SUHRAWARDĪ, op. cit., par. 159 (Corbin, p.144; Walbridge \& Ziai, p.104).

${ }^{232}$ Ibid., par. 162 (Corbin, pp.147-148; Walbridge \& Ziai, p.106).
} 
3. Terceiro tratado: Sobre o modo da atividade da luz das luzes e luzes dominantes e complemento da exposição sobre os movimentos celestes, em quatro seções - a física de Suhrawardī

Ibn Sīnā pensa frequentemente em termos de iluminação $(i \check{r} r a \bar{q})^{233}$. É o caso notável, por exemplo, na célebre passagem do Kitāb al-Šifā (De Anima V, 5, 6) em que Ibn Sīnā retoma a metáfora aristotélica da luz como princípio ativo do conhecimento $^{234}$, mas também em várias passagens em que essa mesma noção designa a luz recebida pela alma se virando tal um espelho em direção ao intelecto agente ou a luz dada pelo existente primeiro às substâncias intelectivas de mais alta classe ${ }^{235}$. Ora, para Suhrawardī, a irradiação das luzes superiores retribuídas cada vez pelo amor das luzes inferiores, se torna o princípio do espelhamento platônico se propagando de múltiplas maneiras e se aplicando pela intensidade decrescente das luzes em todos os níveis de existência e de conhecimento ${ }^{236}$.

O terceiro tratado, o mais breve de todos, intenta completar a exposição sobre a atividade das luzes em suas duas ordens e, sobretudo explicar a relação entre as luzes imateriais, o movimento das esferas e os movimentos do mundo sublunar. Assim, começa por reafirmar que nada resulta da luz das luzes e da inter-relação entre elas, salvo da maneira que se expôs anteriormente. Suhrawardī abre a física celeste de Ibn Sīnā para o alto e para os lados, superpondo duas ordens diferentes de luzes vitoriais (al-anwār al-qāhira): ordem longitudinal (țabaqat al-țul) de luzes vitoriais superiores (al-aclūn), também chamadas de luzes mães (ummahāt) ${ }^{237}$, e a ordem latitudinal (țabaqat al- ${ }^{c}$ arḍ) de luzes vitoriais que são as formas (anwār qāhira șüriyya), isto é, os símiles platônicos ou os "senhores, cujas espécies são os ícones” (arbāb al-aṣnām al$n a w^{c}$ iyya). Com efeito, as luzes não estão ordenadas apenas verticalmente, visto que algumas são diferentes de outras e que, a partir de seus inúmeros aspectos luminosos que atuam entre si, geram-se outras luzes dominantes mais nobres. Por isso, entre elas há "luzes mães", isto é, luzes verticais fundamentais com poucos intermediários

\footnotetext{
${ }^{233}$ A.-M. GOICHON. Lexiquue de la langue philosophique d'Ibn Sīnā (Avicenne). Paris, 1938, p.159. ${ }^{234}$ ARISTÓTELES. De Anima III, 5 (430a 15).

${ }^{235}$ IBN SĪNĀ. Ǐsārāt. pp. 129 e 192, trad. Goichon 331s. e 451s.; ibid. nota 8.

${ }^{236}$ SUHAWARDĪ, op. cit., par. 183 (Corbin, p.170; Walbridge \& Ziai, p.119).

${ }^{237}$ Ibid., par.. 179 (Corbin, p.167; Walbridge \& Ziai, p.117).
} 
luminosos, enquanto outras são luzes horizontais ou símiles, marcadas por raios intermediários $^{238}$. Imediatamente, ao afirmar a eternidade da luz das luzes, que não tem princípio nem fim e que não pode haver nada anterior a essa luz, Suhrawardī polemiza com a crença sustentada pela "gente dos atributos", que defende a ideia de que Deus possui atributos, e polemiza também com os que acreditam que o cosmos tem um começo ${ }^{239}$, mesmo sendo evidente - para Suhrawardī - que este é eterno como sua causa o é - pois não é parte do todo, senão o todo - e, em sua unicidade, reside o fundamento de todas as determinações que definem os existentes particulares de todas as estruturas, nas quais se expressa a organização do universo.

Para Suhrawardī, segundo se pode concluir desse terceiro tratado, não é somente o cosmos uma totalidade, senão um todo único, uma organização universal dentro da qual todos os existentes particulares estão contidos e compreendidos. A ideia de cosmos tem, então, uma significação teológica e não admite uma pluralidade infinita de cosmos. Ademais, se essa organização universal contém as razões de tudo quanto existe, deve-se concebê-la como anterior à existência das coisas. Nesse sentido se considera o cosmos um universo inteligível, como o símile eterno do cosmos físico. Pela unidade e eternidade desse universo inteligível, inferem-se as características de sua natureza, sobretudo sua configuração esférica e seu movimento circular eterno, sem princípio nem fim, como a duração dos ciclos cósmicos que perpetuamente se regeneram e se destroem. O movimento circular e eterno das esferas é o reflexo da complexa atividade das luzes imateriais que se evidenciam desse modo no mundo físico. ${ }^{240}$ Uma vez que deve haver um movimento contínuo sem fim, este deve pertencer às esferas e deve ser circular e causado por algo maior, baseado no princípio da mais nobre contingência ${ }^{241}$. Consequentemente, o movimento é também circular devido a sua imitação do único amado, isto é, da luz das luzes ${ }^{242}$. As esferas em seus movimentos, inter-relações e correspondências se assemelham, assim, às relações das “entidades sagradas" ou luzes imateriais ${ }^{243}$. O movimento das esferas se produz pelas

\footnotetext{
${ }^{238}$ Ibid., par. 183 (Corbin, p.170; Walbridge \& Ziai, p.119).

${ }^{239}$ Ibid., par. 177 (Corbin, pp.163-164; Walbridge \& Ziai, p.115).

${ }^{240}$ Ibid., par. 177 (Corbin, pp.163-164; Walbridge \& Ziai, p.115).

${ }^{241}$ Ibid., par. 178 (Corbin, pp.165-166; Walbridge \& Ziai, pp.116-117).

${ }^{242}$ Ibid., par. 182 (Corbin, p.169; Walbridge \& Ziai, p.119).

${ }^{243}$ Ibid., par. 180 (Corbin, pp.166-167; Walbridge \& Ziai, p.117).
} 
luzes regentes imateriais ${ }^{244}$, sem conexão com os limítrofes, determinado também pelo amor e pelo desejo, que é a própria condição pela qual ocorre a iluminação proporcional à sucessão de irradiações ${ }^{245}$. A luz que rege esse movimento não é a luz dominante em sua perfeição, senão a luz regente adquirida pelos símiles ${ }^{246}$.

Suhrawardī aproveita para polemizar com os "seguidores dos peripatéticos", visto que, para os mesmos, é somente ao cosmos visível que se concede o atributo de eternidade e, não é eterno apenas em sua matéria - que é indestrutível -, mas também em sua organização que não pode ser resultado de nenhuma mudança. É sem começo e sem fim e, segundo os mesmos, existirá sempre na infinidade dos tempos. Para os mesmos, o objetivo do movimento das esferas é o movimento dos planetas. Entretanto, o movimento dos planetas é, por vezes, constata Suhrawardī, retrógrado e retilíneo ${ }^{247}$ e, assim, obedece à correspondência de domínio e amor das luzes que se repete ao longo dos tempos. Justamente pela realidade dessas direções, os movimentos são distintos. Há os que se movimentam circularmente, isto é, ao redor do centro, ou os que se movimentam em linha reta. Estes últimos quando se dirigem para o centro tem por propriedade o frio e se estão longe do centro, sua propriedade é o calor.

Pode-se concluir que o eterno e a eternidade não são a luz das luzes, senão uma das dimensões pertencentes à própria luz das luzes e que dela flui, do mesmo modo que dela flui a evidenciação de si e de seu esplendor. Sendo a luz das luzes uma totalidade, seja na totalidade de todo inteligível seja em suas características particulares, é plena e sem deficiência, carece de não-ser e não pode esperar quaisquer surpresas, nem que haja começado em algum momento. Por isso é inespacial e atemporal.

Com relação ao tempo - que Suhrawardī procura não confundi-lo com a eternidade, visto ser um atributo que se gera da luz das luzes - é o que chega a ser e que tem sua origem na eternidade e que uma vez gerado, espera ser. Nesse sentido, a atividade própria da alma, como seu reflexo, é a imagem da eternidade e assim vida

\footnotetext{
${ }^{244}$ Ibid., par. 190 (Corbin, pp.174-175; Walbridge \& Ziai, p.121).

${ }^{245}$ Ibid., par. 191 (Corbin, p.175; Walbridge \& Ziai, p.122).

${ }^{246}$ Ibid., par. 191-192 (Corbin, pp.175-176; Walbridge \& Ziai, pp.122-123).

${ }^{247}$ Ibid., par. 182 (Corbin, p.169; Walbridge \& Ziai, p.118).
} 
temporal já que, na medida em que exibe universalmente sua potência, se vai temporalizando. O tempo é entendido como a extensão da vida da alma, uma extensão que se expande e que, como desejo permanente, nasce em germe, se desenvolve para se realizar e, esgotadas suas possibilidades, busca retornar à eternidade. Há, dessa maneira, uma temporalidade intrínseca ao universo e aos existentes desde as esferas das estrelas fixas até a mais humilde das vidas orgânicas que existem na Terra. Tratase do "contínuo amor e desejo eterno" 248 de permanecer, a causa a que se deve a rotação incansável dos céus.

Recorrendo à tradição filosófica grega sobre a eternidade o tempo, Suhrawardī conclui esse tratado repetindo que a luz das luzes é a causa do próprio cosmos e de sua continuidade e é a geração de luz que determina a identidade e a essência dos existentes.

4. Quarto tratado: sobre as divisões dos limítrofes, sobre suas qualidades, sua composição e algumas de suas propriedades, em oito seções - a continuação da física de Suhrawardī e apresentação de sua antropologia: fundamentação da psicologia de Suhrawardī

Uma vez terminado seu estudo sobre a atividade das luzes, Suhrawardī descreve o mundo do corpo e da alma. Como já se viu, sua física está fundada na luz e em seus graus de intensidade, não em forma e matéria aristotélicas, que Suhrawardī rechaça em sua crítica à teoria hilemórfica que era predominante em seu tempo, mesmo fora dos círculos dos peripatéticos, visto ser a posição, por exemplo, da escola teológica ašari que baseava o estudo da física no princípio da matéria. Cada corpo tem, segundo Suhrawardī, uma propriedade essencial, que é sua finitude ou limitação em forma e em dimensão. Ao recusar o átomo como substância elementar, sustenta que ainda que não se possa seguir dividindo um corpo fisicamente, poder-se-á fazê-lo intelectualmente. Cada corpo absoluto é a dimensão absoluta como os corpos particulares são as dimensões particulares. Dado que a corporeidade está unida à tenebrosidade, representada pelo limítrofe, todos os corpos tem graus de luzes e de

\footnotetext{
${ }^{248}$ Ibid., par. 191 (Corbin, p.175; Walbridge \& Ziai, p.122).
} 
sombras e, o estudo da física será, portanto, o estudo da luz e de seus graus de intensidade.

Suhrawardī apresenta três grupos, segundo sejam transparentes ou sutis: o que barra a luz e a impede de adentrar (1); o que é transparente à luz e não a barra (2); e o que permite a entrada dos diversos graus de luz (3) que, por sua vez, se divide em vários outros grupos ${ }^{249}$. Os céus pertencem ao segundo grupo por causa de seu estado luminoso, a terra ao primeiro, a água ao segundo em seu estado normal e o ar ao terceiro que consiste em muitos graus. $\mathrm{O}$ fogo, um dos quatro elementos tradicionais, “tem a luz por essência e sua nobreza obtém necessariamente dela sua luminescência. O fogo, os antigos persas estão de acordo em vê-lo como a teurgia do arcanjo Urdibihišt, isto é, da luz dominante que se infunde sobre si mesmo"250. Trata-se de uma forma de luz, irmã da alma humana e vice-regente da luz suprema. Suhrawardī pode assim refutar "alguns peripatéticos que dizem que há quatro princípios de receptáculo"251: o frio e o seco (terra) (1); o frio e o úmido (água) (2); o calor e o úmido (ar) (3); e o calor e o seco (fogo) (4). Suhrawardī admite as quatro qualidades primárias dos corpos: calor, frio, umidade e secura. Suas combinações dão lugar aos quatro elementos - terra, água, ar e fogo - que necessitam de um receptáculo que é a matéria, isto é, a tenebrosidade. Pode-se, desse modo, avançar na discussão dos diferentes fenômenos físicos, em particular os meteorológicos, seguindo o esquema peripatético, mas com uma ênfase diferente. Assim, por exemplo, ainda que Suhrawardī aceite a exalação e a teoria do vapor, acentua a importância da luz em tudo isso. Com efeito, todo o estudo dos corpos está baseado essencialmente em seu caráter de limítrofe entre os diferentes graus de luz que refletem e transmitem gradualmente.

Os corpos são governados pelos céus, estes pelas almas, estas por várias ordens de luzes e estas ordens pela luz das luzes, que domina assim todo o cosmos. As iluminações, entrementes, que recebem esses corpos e seus movimentos procedem das luzes dominantes e sua causa direta é a luz regente, associada aqui ao calor e ao fogo que, por sua vez, é originário da irradiação das luzes imateriais. A diversidade e a

\footnotetext{
${ }^{249}$ Ibid., par. 194 (Corbin, pp.179-180; Walbridge \& Ziai, p.124).

${ }^{250}$ Ibid., par. 201 (Corbin, p.184; Walbridge \& Ziai, p.128) e par.196 (Corbin, pp.181-182; Walbridge \& Ziai, p.126).

${ }^{251}$ Ibid., par. 195 (Corbin, p.180; Walbridge \& Ziai, p.125).
} 
multiplicidade de seus efeitos se devem à mesma diversidade e capacidade de recepção.

A luz é a que transmite calor e gera o movimento. Suhrawardī insiste em afirmar que o fogo é o calor mais perfeito e o que está mais próximo da natureza da luz. "Porque o fogo é assim que, nos tempos passados, os persas prescreveram de se cultuá-lo e de orar em sua direção",252.

A partir desses elementos se geram os minerais, as plantas e os animais em distintos graus de perfeição. Os três reinos são, por assim dizer, produto de sua mescla e cada um reflete um símile particular. No domínio mineral, o ouro, por exemplo, tem um brilho especial e tem o efeito de levar a alegria às almas, porque a luz que contém está relacionada com a da alma humana e com o fogo. Semelhantemente, nas plantas e nos animais, a luz angélica domina e governa as funções de cada espécie ${ }^{253}$.

A constituição mais perfeita pertence a quem invoca a perfeição do grande doador. Entre as luzes dominantes há uma delas que domina o corpo humano ou fortaleza ( $\operatorname{sis} \overline{i j} a$ ), mistura de terra e água, ou seja, de argila. Essa luz é Gabriel, o patriarca entre os senhores do reino do domínio. É doador do espírito, o espírito santo, doador do conhecimento e da confirmação, da vida e da virtude. Essa luz irradiada é a luz regente, a que comanda (isfahabad, comandante) a humanidade que é definitivamente a alma humana ou "a perfeição primeira de um corpo natural orgânico" 254 . Assim, essa luz-alma é a que comunica a identidade a cada sujeito e que o ilumina e o provê de capacidade para iniciar a viagem de retorno. O corpo é um recipiente ou receptáculo preparado para receber a luz regente, cujo movimento iluminativo lhe permite buscar sua ascensão às puras luzes ${ }^{255}$ e cuja relação se produz segundo os princípios do amor e do domínio.

O homem também necessita de uma hierarquia que participe e se assemelhe com a hierarquia cósmica. Assim, para Suhrawardī, as diferentes capacidades humanas estão intimamente relacionadas com a sua epistemologia e, por conseguinte, com suas

\footnotetext{
${ }^{252}$ Ibid., par. 206 (Corbin, p.188; Walbridge \& Ziai, p.130).

${ }^{253}$ Ibid., par. 208-209 (Corbin, p.189; Walbridge \& Ziai, p.131).

${ }^{254}$ Ibid., par. 211 (Corbin, p.191; Walbridge \& Ziai, p.132).

${ }^{255}$ Cf. Ibid., par. 211-214 (Corbin, pp.190-192; Walbridge \& Ziai, pp.132-133).
} 
cosmologia e escatologia, visto que o fim do homem é reconstruir a cadeia de transmissão que conduz a sua pessoa, testemunhando a ascendência luminosa a que é chamado através das gerações. No entanto, tais genealogias designam algo cuja verdade meta-histórica não deve ser considerada inferior já que é de uma ordem distinta da verdade materialmente histórica. Por isso, nos introduz imediatamente na estrutura do existente. Suhrawardī segue aqui o esquema de Ibn Sīnā ao enumerar as faculdades das almas vegetativas e animais. As primeiras possuem três atividades básicas: nutrir, crescer e reproduzir. As segundas tem o poder adicional do movimento e da percepção. Mas essas faculdades são apenas aspectos ou divisões da alma presente em cada uma das espécies e devem ser compreendidas sempre com referência à luz. O homem, por ser o mais perfeito dos animais, possui o sentido e cinco faculdades externas compartilhadas com o resto dos animais (tato, paladar, olfato, audição e visão) e cinco internas, recebidas da luz comandante (anwār alisfahbad $\bar{\imath})^{256}$, ainda que possam ser mais, dirigidas ou governadas pela alma racional (al-nafs al-natīqa). Mas, por sua vez, o pneuma (rūh) ou substância sutil ${ }^{257}$ disperso pelo corpo é o ponto de unidade e luminosidade para essas capacidades ${ }^{258}$. Estas capacidades são:

1) sentido comum (hiss muštarak) $)^{259}$, a faculdade na qual se combinam os cinco sentidos;

2) imaginação $(h a y \bar{a} l)^{260}$, na qual se recolhem as imagens sensíveis quando já não estão presentes na sensação;

3) imaginativa (mutahayyila) ${ }^{261}$ combina as formas sensíveis para o uso do pensamento, analisando e sintetizando. Associa e separa imagens. Para Suhrawardī, a imaginação é a faculdade estimativa (wahm, por meio da qual se elaboram conceitos e juízos); assim, a estimativa e a imaginativa são, com efeito, uma mesma, apesar de que se pode denomina-las de diferentes maneiras ${ }^{262}$;

\footnotetext{
${ }^{256}$ Ibid., par. 217 (Corbin, p.194; Walbridge \& Ziai, p.134).

${ }^{257}$ Ibid., par. 218 (Corbin, p.194; Walbridge \& Ziai, p.135).

${ }^{258}$ Ibid., par. 219 (Corbin, p.195; Walbridge \& Ziai, pp.135-136).

${ }^{259}$ Ibid., par. 226 (Corbin, p.200; Walbridge \& Ziai, p.139).

${ }^{260}$ Ibid., par. 221 (Corbin, pp.196-197; Walbridge \& Ziai, p.136).

${ }^{261}$ Ibid., par. 225 (Corbin, p.199; Walbridge \& Ziai, p.138).

262 Ibid., par. 224 (Corbin, p.; Walbridge \& Ziai, p.138). Cf. par. 222 (Corbin p.; Walbridge \& Ziai, p.137).
} 
4) apreensão (idrāk), conhecimento direto de algo, sendo, assim, a intuição ou a percepção sensível;

5) memória (hafiza $)^{263}$, tudo aquilo que se recorda e pelo qual não se pode esquecer algo. Trata-se de uma potência anímica e ativa que se revigora pela luz $z^{264}$

Todas as capacidades da alma se convertem em um único poder, a capacidade de configurar a imaginação, que se transforma em uma percepção sensível do suprassensível, visto que a própria visão imaginativa é como a visão sensível. Da mesma maneira que com a visão, ocorre com o ouvido (a audição imaginativa é como a audição sensível); do mesma maneira com o olfato, o paladar e o tato: todos os sentidos são semelhantes às faculdades sensíveis, sendo ordenados, porém, ao suprassensível. Se exteriormente as faculdades são cinco, tendo cada qual o seu órgão localizado no corpo, interiormente todas constituem um único sentido comum. Por isso, Suhrawardī afirma que aquilo que está disperso no corpo retorna finalmente a uma unidade por meio dessa capacidade interior ${ }^{265}$. Assim, a imaginação é similar ao corpo sutil da alma e, por isso, o "corpo da ressurreição", suporte e meio de elevação para o retorno da alma. Suhrawardī reprovará em Ibn Sīnā o fato de este haver identificado os atos de percepção imaginativa de outro mundo com o que se sucede na vida terrena durante o sonho, pois na terra, a potência imaginante é alterada pelas operações orgânicas que se realizam no corpo físico. Esta imaginação espiritual é uma potência cognitiva, verdadeiro órgão de conhecimento que transcende e determina o indivíduo. A percepção e a consciência imaginante têm sua função e o seu valor noético próprios em relação com o mundo que lhes é próprio. A imaginação se encontra assim solidamente situada e fixada entre outras duas funções cognitivas, fortalecidas no sábio: na sabedoria discursiva e na sabedoria intuitiva. Há, pois, um controle que preserva a imaginação de divagações que lhe permite assumir com pleno direito a sua finalidade.

Para concluir esse tratado, Suhrawardī introduz o conceito de "formas suspensas" (sūwar mucallaqa) ${ }^{266}$, ampliando-o em seu ultimo tratado. É nessa

\footnotetext{
${ }^{263}$ Ibid., par. 219 (Corbin, pp.195-196; Walbridge \& Ziai, pp.135-136).

${ }^{264}$ Ibid., par. 220 (Corbin, p.196; Walbridge \& Ziai, p.136).

${ }^{265}$ Ibid., par. 226-227 (Corbin, pp.200-201; Walbridge \& Ziai, p.139).

${ }^{266}$ Ibid., par. 225 (Corbin, p.199; Walbridge \& Ziai, p.138).
} 
capacidade imaginante que se suspendem as formas contidas na imaginação. São figuras que se dão nos sonhos, nos espelhos e nas visões, mas que não são materiais, apenas imagens, cujo exemplo Suhrawardī oferece ao afirmar que uma luz material é a imagem, enquanto reflexo, da luz perfeita ${ }^{267}$.

É o conhecimento imediato ou presencial ( ${ }^{c} i l m$ hud $\left.u \bar{u} r \bar{\imath}\right)$, cujo princípio se trata na percepção sensível ou espiritual; é um simples conhecimento por contato direto, uma relação iluminatriz (ị̣̂âfa išrāqūya) entre o olho - ou a substância luminosa "regente" (al-nūr al-mudabbir), isto é, a alma - e a coisa iluminada (muqābalat almustanīr $)^{268}$. Derivando tal conhecimento iluminativo do conhecimento nãomediatizado que se tem de si mesmo, Suhrawardī se encontra ainda sob influência de Ibn Sīnā $\overline{2}^{269}$; mas Suhrawardī estende o princípio ao conhecimento das coisas "ausentes" igualmente, que tornam simplesmente "presentes" (istihḍr) os símiles universais na alma, as formas particulares na imaginação. Esta desempenha um papel de espelho para a alma, metáfora privilegiada de Suhrawardī para o "lugar da aparição" (maz̧har) na qual os particulares se mostram "em suspenso" (mucallaqa).

Sabes já que a impressão das formas no olho é impossível; por analogia, sabes que é impossível que as formas sejam impressas em um local do cérebro. A verdade sobre as formas refletidas nos espelhos e nas formas imaginais (suwar hayāliyya) é que elas não são impressas, mas que são "cidadelas em suspenso" ( $m u^{c}$ allaqa) que não tem substrato. Elas têm lugares de epifania, mas não estão nesses lugares. Assim o espelho é o lugar da aparição das formas que são vistas e estas estão "em suspenso", não em um espaço tampouco em um receptáculo. Da mesma forma a imaginativa (tahayyul) é o lugar de aparição das formas da imaginante (hayāl) e estas são as "formas em suspenso".

Admitindo-se a existência de uma imagem imaterial (mițāl mujarrad), cuja natureza é plana, sem profundeza nem superfície - tal imagem é própria ao espelho -, imagem subsistente por si mesma, e que o que provém dessa imagem (mā huwa minhu) é um acidente, autêntica será a existência de uma

\footnotetext{
${ }^{267}$ Ibid., par. 225 (Corbin, p.200; Walbridge \& Ziai, p.138).

${ }^{268}$ Ibid., par. 101-104 (Walbridge \& Ziai, pp.70-73); 145 (Corbin, p.129; Walbridge \& Ziai, p.96); par. 225-228 (Corbin, p.199-201; Walbridge \& Ziai, pp.138-140).

${ }^{269}$ PINĖS, S. «La conception de la conscience de soi chez Avicenne et chez Abu'l-Barakāt alBaghdādī », Archives d'Histoire doctrinalle et littéraire du Moyen-Age 21, 1954, pp. 21-98, p. 36.
} 
quididade substancial, que possui uma imagem acidental, e a luz imperfeita é como uma imagem da luz perfeita. Compreendas! $!^{270}$

\section{Quinto tratado: Sobre o retorno, as profecias e os sonhos, em nove seções - o retorno ao uno. A escatologia e a profetologia de Suhrawardī.}

O ponto central desse último tratado é o mundo da imagem como estado intermediário entre o mundo físico e o mundo imaterial. Começa com uma discussão, às vezes contraditória e ambígua, com respeito à noção de transmigração ${ }^{271}$. Em seus trabalhos, Suhrawardī mantém vários pontos de vista, desde uma absoluta recusa até certa simpatia em relação à transmigração. Sua intenção aqui é, conforme o próprio título que Suhrawardī dá ao primeiro tópico dessa seção, clarear o conceito de transmigração, perguntando-se “o que é a transmigração?” No lugar de examinar os argumentos possíveis sobre tal tema, Suhrawardī prefere recordar com certo detalhe o ponto de vista daqueles que sustentam tal doutrina como "Budasf" e os sábios anteriores a ele, que afirmaram que a porta das portas para vida é o corpo humano"273. Tendo isso em conta, só o corpo estaria preparado para receber a luz regente (isfahbad) emitida diretamente das luzes vitoriais. Os "corpos mudos", ou seja, os animais, ao contrário, receberiam apenas almas humanas imperfeitas, segundo foram os seus atos morais em vidas passadas com a finalidade de se purificar. Com efeito, Suhrawardī afirma que essa "possibilidade da transmigração das almas está explicitamente excluída tanto nos corpos humanos como nos corpos animais"274. Suhrawardī diz que "Platão e os sábios, seus predecessores, professam a transferência

\footnotetext{
${ }^{270}$ SUHRAWARDĪ, op. cit., par. 225 (Corbin, pp.199-200; Walbridge \& Ziai, p.138).

${ }^{271}$ M. Smith, em "Transmigration of the Sufis" em Moslem World 30 (1940), pp. 354, sustenta que Suhrawardī é um entusiasta da doutrina da transmigração. No Livro da sabedoria da iluminação isso é negado. Smith afirma que nessa obra em questão, Suhrawardī não quis criar polêmicas desnecessárias, visto que para o seu sistema filosófico - como bem explica - a transmigração não é de grande importância. Por outro lado, Guy Monnot, em "La Transmigration et l'inmortalité" [MIDEO 14 (1980)], sustenta o rechaço de Suhrawardī, em todo o seu sistema, a possibilidade da transmigração das almas. A interpretação de Monnot nos parece ser a mais razoável.

${ }^{272}$ Budasf deriva de Bodisatva que dentro do islã é a forma pela qual Buda era conhecido. Trata-se de uma peça importante a se por na influência do budismo entre os escritores muçulmanos e entre os filósofos árabes. Ver «Boudha et les boudhistes dans la tradition musulmane » por D. GIMARET. Journal Asiatique, 253,3-4, de 1969.

${ }^{273}$ SUHRAWARDĪ, op. cit., par. 230 (Corbin, p.204; Walbridge \& Ziai, p.142).

${ }^{274}$ Ibid., par. 235 (Corbin, p.207; Walbridge \& Ziai, p.144).
} 
(naql), bem que haja divergências concernentes à maneira de compreender esta transmigração." ${ }^{275}$ Inclusive,

certos pensadores do islã selecionaram alguns versículos da revelação tal qual: "Todas as vezes que sua pele secar, nós a substituiremos por outra" (IV, 59), "Cada vez que querem sair dele, eles serão devolvidos" (XXII, 22; XXXII, 20), "Não há besta sobre a terra nem pássaro voando com suas asas que não formem uma comunidade que não vos seja semelhante" (VI, 38). E múltiplos são os versículos da zoomorfose (mash) e os hadīt concernentes ao fato que os homens ressuscitarão em formas diferentes, segundo o seu comportamento. Do mesmo modo, na revelação é mencionada uma história (hikāya) sobre os reprovados: "Senhor, tu nos fizeste morrer duas vezes e tu nos reanimaste duas vezes; nós reconhecemos nossos delitos. Não há caminho para sair daqui?" (LX, 11). Ou ainda o versículo que concerne às bem-aventuranças: "Não conhecerão mais a morte depois da primeira morte" (XL, 56), etc. ${ }^{276}$

Suhrawardī, enfim, recorda que a maior parte dos filósofos concordam que ao morrer, as almas perfeitas escapam imediatamente para o mundo da luz ( ${ }^{c} \bar{a} l a m$ al-nür $)$, sendo os mesmos que se inclinam para a doutrina da transmigração. Pode-se perceber que Suhrawardī procura ser cuidadoso com relação a esse tema que, como se vê, o próprio autor considera controvertido.

Suhrawardī afirma que o corpo é a primeira estação da alma no mundo da matéria $^{277}$, a alma é inalterável e não pode ser destruída após a morte ${ }^{278}$, mas retorna à sua causa ${ }^{279}$ e o corpo se decompõe e sua constituição se destrói.

\footnotetext{
${ }^{275}$ Ibid., par. 235 (Corbin, p.206; Walbridge \& Ziai, p.143).

${ }^{276}$ Ibid., par. 235 (Corbin, p.206-207; Walbridge \& Ziai, p.144).

${ }^{277}$ Ibid., par. 229 (Corbin, pp.203-204; Walbridge \& Ziai, p.141).

278 "Saibas que é inconcebível que a luz imaterial regente seja ela mesma anulada depois da destruição $\left(f a n \bar{a}^{\prime}\right)$ de sua cidadela. Com efeito, a luz imaterial não implica sua anulação; senão ela não existiria. Além disso, sua existenciadora, isto é, a luz dominante, não pode anulá-la, uma vez que é inalterável. Como, ademais, uma coisa destruiria espontaneamente (bi-dati-hi) o que é inerente à sua própria essência? Como a luz poderia suprimir a sua própria irradiação e o seu próprio clarão?” Ibid., par. 236 (Corbin, p.207; Walbridge \& Ziai, p.144).

${ }^{279}$ Ibid., par. 236 (Corbin, pp.207-208; Walbridge \& Ziai, pp.144-145), par. 237 (Corbin, pp.208-209; Walbridge \& Ziai, p.145), par. 241 (Corbin, pp.211-212; Walbridge \& Ziai, p.147) e par. 274 (Corbin, p.229; Walbridge \& Ziai, pp.160-161).
} 
No segundo tópico, "como as luzes puras escapam para o mundo da luz", Suhrawardī é claro ao expor a sua escatologia: se as barreiras ou obstáculos não distraírem a alma, esta desejará o mundo da luz sagrada no lugar das trevas. Aperfeiçoará o seu clarão e seu maior desejo será sua independência e proximidade com as luzes mães e com a luz das luzes. Não voltará a outro corpo em virtude de sua luminosidade crescente ${ }^{280}$ e será sagrada por meio da sacralidade da luz das luzes. No amor à luz das luzes e no domínio sobre o corpo se evidencia a perfeição da alma. Disso resulta o desejo de ressureição, o "prazer infinito" 281 .

Suhrawardī postula a existência autônoma de um verdadeiro mundo de imagens ou formas separadas diferentes dos símiles platônicos, pois esse mundo compreende não apenas as luzes, mas também as trevas e se acrescenta como um quarto domínio ao dos intelectos, das almas e dos $\operatorname{corpos}^{282}$. Trata-se do mundo dos símiles ( ${ }^{c} \bar{a} l a m$ al-mitâa $\left.l\right)^{283}$. Assim, Suhrawardī consegue justificar a escatologia religiosa dos "corpos sutis"; mas essa escatologia concerne apenas aos "razoavelmente avançados"284. Ademais, a realidade do mundo dos símiles se justifica pelo fato psicológico das visões e dos sonhos, e também pela existência de jinn e šayāțīn, seres independentes de seus locais de aparição, pois eles são capazes de se mover. Como apoio a esse argumento empírico, Suhrawardī inclui os testemunhos oculares que

\footnotetext{
${ }^{280}$ Ibid., par. 237 (Corbin, pp.208-209; Walbridge \& Ziai, pp.145-146).

${ }^{281}$ Ibid., par. 239 (Corbin, p.210; Walbridge \& Ziai, p.) e par.241 (Corbin, pp.211-212; Walbridge \& Ziai, p.147).

${ }^{282}$ Ibid., par. 246-248 (Corbin, pp.214-216; Walbridge \& Ziai, pp.149-150).

${ }^{283}$ Suhrawardì nos parece ser o primeiro filósofo a postular a existência autônoma de um verdadeiro mundo de símiles diferentes dos símiles platônicos, pois esse mundo compreenderia não apenas as luzes, mas também as trevas, acrescentando como que um quarto domínio, junto com os intelectos, as almas e os corpos [Ibid., par. 246-248 (Corbin, pp. 214-216; Walbridge \& Ziai, pp. 149-150)]. Esse quarto mundo é chamado de ${ }^{c} \bar{a} l a m$ al-mițāl (mundo dos símiles), geralmente traduzido como mundus imaginalis. Para Suhrawardī, se trata de um universo que mantém analogias tanto com a substância corporal - possui forma, dimensões e extensão - como com a substância luminosa (munīr, nūranī). Assim, trata-se de matéria imaterial e incorporeidade corporalizada em um corpo sutil (jism lațîf).

${ }^{284}$ Ibid., par. 242-243 (Corbin, pp.212-213; Walbridge \& Ziai, pp. 147-148).
} 
havia encontrado no Azerbaijão ${ }^{285}$, lugar em que cresceu, e de suas viagens pela Ásia Menor $^{286}$.

A viagem da alma no momento em que escapa de sua prisão depende do grau de cada uma para ascender na hierarquia antes da morte, no instante, no aqui e agora $^{287}$. Assim, Suhrawardī considera que uma vida balanceada e harmoniosa baseada no conhecimento e na ascese é a chave para o retorno, determinando, desse modo, o estado da alma após a morte. É aqui que se encontra a contribuição original do autor quando incorpora o conceito de "formas suspensas" em sua escatologia. Suhrawardī recorda que essas formas são diferentes dos símiles platônicos e as descreve deste modo: "as formas suspensas não são os símiles platônicos, uma vez que estes são luminosos, enquanto que algumas das formas suspensas são obscuras e outras luminosas",288. Denomina-as também de "o mundo das figuras imateriais" ou "a ressurreição das imagens" que "podem ser renovadas ou destruídas como as imagens nos espelhos" e que "não podem ser atribuídas ao sentido comum [...], visto que todas as promessas das profecias encontram a sua realidade por meio delas"289

Ao concluir esse tratado, Suhrawardī confirma que as almas daqueles que tiveram uma vida harmoniosa aspiram a uma ordem luminosa superior. Conclui que cada estatuto de existência dos indivíduos está determinado sobre a base de hierarquia e de estados. Em outras palavras, o peregrino totalmente rico é aquele cuja essência depende apenas da luz das luzes. Por isso, Suhrawardī descreve em sua obra, as quinze

${ }^{285}$ Ibid., par. 246 (Corbin, p. 214; Walbridge \& Ziai, p. 149). Aí são nomeadas as cidades de Darband e Miyānīj. Esta cidade fica no país do Azerbaijão, chamando-se hoje Muyāna, situada a $150 \mathrm{~km}$ de Suhraward. A cidade de Darband pode remeter a diversos locais. Em todo caso, parece se tratar de regiões da Mesopotâmia superior, do Azerbaijão ou do Curdistão em que se sabe que Suhrawardī muito viajou antes de se fixar em Alepo (LANDOLT, H., op. cit., p. 239, nota 25).

${ }^{286}$ Esse ponto fez com que Suhrawardī fosse aproximado com o sufismo. Um interesse pelas "aparições reais" do mundo suprassensível se manifesta em certos autores célebres como Najm al-Dīn al-Kubrā (m. 1221) e Ibn 'Arabī, ou, entre os contemporâneos de Suhrawardī, Šams al-Dīn al-Daylamī (m. 1197) e seu discípulos Maḥmūd-i Ušnuhī. Talvez seja apenas coincidência, mas chama a atenção que em alDaylamī e em Ušnuhī, contemporâneos de Suhrawardī, mais ou menos originários da mesma região e que habitaram no Azerbaijão, que se encontre o início de uma teoria original de um espaço sutil (makān lațîf) autônomo, lugar natural dos demônios e dos espíritos. Em todo caso, a alusão de Suhrawardī aos testemunhos oculares de Darband e Miyāna, os quais permanecem, no entanto, anônimos, é o único indício que poderia eventualmente fornecer uma ligação concreta entre o filósofo Suhrawardī e os meios sufis de sua terra natal, o que poderia, de alguma maneira, ter influenciado em sua formação. (LANDOLT, H. op. cit., p. 239).

${ }^{287}$ SUHRAWARDİ, op. cit., par. 244 (Corbin, pp.213-214; Walbridge \& Ziai, pp.148-149).

${ }^{288}$ Ibid., par.. 246 (Corbin, p.214; Walbridge \& Ziai, p.149).

${ }^{289}$ Ibid., par. 248 (Corbin, p.215; Walbridge \& Ziai, p.150). 
classes de luz que conduzem ao conhecimento experiencial para aqueles que buscam o retorno. Diz que os que se livram do mundo da matéria estão capacitados para chegar ao "oitavo céu", entre os quais menciona, a título de exemplo, Platão, Hermes e os grandes sábios, Muhammad (o autor da Lei) e com ele um grupo dos que se despiram de sua condição humana ${ }^{290}$. Assim, para Suhrawardī, essas luzes, algumas das quais têm uma descrição peculiar, são o "propósito do caminho de Deus" e irradiam desde o alto, sendo a essência e o poder da sabedoria e aquele que as experimenta alcançará o poder para se despreender do mundo material:

1) uma luz que brilha sobre aquele que busca, jubilosa, mas não permanentemente;

2) uma luz brilhante similar a um relâmpago;

3) uma luz que entra no coração dos contemplativos, como se se esparramasse um pouco de água morna sobre a cabeça;

4) uma luz desce sobre o coração dos homens e que aí permanece, sendo uma luz dominante que induz a um tipo de embriaguez;

5) uma luz de extrema graça e prazer produzida por meio do poder do amor;

6) uma luz que queima e é gerada pelo conhecimento;

7) uma luz muito luminosa, cujo clarão supera o do sol;

8) uma luminosidade que se dispersa como se caísse do cabelo e permanecesse;

9) uma luz que flui, dolorosa e ao mesmo tempo agradável;

10) uma luz proveniente de algumas figuras e ficções cerebrais;

11) uma luz que irradia da alma e brilha sobre todos os componentes espirituais;

12) uma luz cuja obtenção está marcada por sua intensidade;

13) uma luz que dá nascimento à alma e que aparece suspendida, podendo se observar a imaterialidade da alma por meio dessa luz;

14) uma luz que induz um peso especial como se se exercera pressão para além de sua própria habilidade; e

15) uma luz que é a causa de todos os movimentos do corpo ${ }^{291}$.

${ }^{290}$ Ibid., par. 274 (Corbin, p.229; Walbridge \& Ziai, p.161).
${ }^{291}$ Ibid., par.272 (Corbin, pp.228-229; Walbridge \& Ziai, pp.159-160). 
Essas luzes, que compõem a vida de cada buscador, são estações (maqāmāt $)^{292}$ que representam a procura de um estado perfeito, experimentado pelos que se purificaram e se prepararam, associadas com "a estação dos irmãos da pureza ou a estação da existência"293.

Por fim, Suhrawardī estabelece a sua profetologia ${ }^{294}$. A alma, quando completa sua invocação ou memorização $(\underline{d} i k r)^{295}$ e se consolida na santidade, seu grau de proximidade com a luz criadora aumenta de tal modo que se converte na alma do mundo. Quanto mais luz recebe ou quanto mais transparente é o véu, mais próxima está de seu Senhor, na medida que se liberta das barreiras do mundo material. Sem esperar a morte, os peregrinos cujas almas receberam a irradiação (sakinna) testemunham com sua vida, o desejo de se fundir no mundo da luz.

Como fez no começo dessa obra, ao final, Suhrawardī se dirige àqueles que estão esperando e que pediram para o filósofo escrever o seu sistema filosófico:

Exorto-os, meus irmãos, a preservar este livro, guardá-lo e afastá-lo daqueles que são indignos dele. Deus é que os governará. Completei a sua composição no último dia do mês de Jumādā al-Ahira do ano 582, no dia que os sete planetas estavam abaixo do signo de libra, ao final do dia. Entreguem-no somente àqueles bem versados no método dos peripatéticos e amantes da luz

\footnotetext{
292 Ibid., par. 273 (Corbin, p.229; Walbridge \& Ziai, p.160).

${ }^{293}$ Ibid., par. 259 (Corbin, p.222; Walbridge \& Ziai, p.155).

${ }^{294}$ Suhrwardī pretenderia fazer uma profetologia a partir de sua ciência das luzes? Ġazālī em sua obra Miškāt al-anwār comenta um versículo corânico (XXIV, 35) que fala de Deus enquanto luz do céu e da terra. O nome luz se aplica, de forma exata, a Deus somente, e aos outros existentes luminosos por derivação. Percebe-se algo visível pela vista ou invisível pela razão pelo fato da luz tornar as coisas manifestas ou perceptíveis. A visão e, principalmente, a razão, tem uma analogia com Deus, craidor de Adão, o símile da natureza racional, própria imagem de Deus. Entre os existentes luminosos mais próximos de Deus estão Adão e os demais profetas - entre os profetas, o mais luminoso é Muhammad. Haveria repercutido esse tema no pensamento de Suhrawardī? Não sabemos responder. A repercussão desse tema é visível em Ibn ${ }^{\mathrm{c}} \mathrm{Arab} \overline{1}$, visto que para ele há uma realidade pré-eterna, que é o protótipo de toda a criação e em particular nos profetas. Esta realidade se chama luz maometana (nūr muhammadī) ou realidade maometana (haqīqa muhamadiyya). Mais visível ainda é em Fah̆r al-Dīn al-Rāzī ao citar textualmente a obra de Ġazālī: os versículos do Alcorão são para o olho da inteligência o que a luz solar é para o olho sensível; assim, a luz do Alcorão é semelhante à luz solar e a luz da inteligência semelhante à luz do olho. (cf. ARNALDEZ, Roger. Les Sciences Coraniques: Grammaire, droit, théologie et mystique. Paris : Vrin, 2005, pp. 54 e 56).

${ }^{295}$ Ibid., par. 261 (Corbin, p.223; Walbridge \& Ziai, p.156).
} 
de Deus. Permitam-lhe meditar por quarenta dias, abster-se de carne, comer pouco alimento, e se concentrar na contemplação da luz de Deus ${ }^{296}$.

Suhrawardī apresenta três argumentos para sustentar sua ciência das luzes e a luz como realidade fundamental: que o criador é luz, que a existência é um construto e que o que é evidenciado se conhece por si mesmo por meio da experiência direta e iluminativa. Da luz das luzes depende todo o cosmos, mas sua criação se gera a partir de seu primeiro efeito, a luz próxima, que contém a multiplicidade. Suhrawardī é mais preciso ao aplicar as suas principais observações à cosmologia, visto que não apenas o criador de tudo o que há é luz, mas que os intelectos imateriais são luzes e que são mais de nove ou dez ou onze e que cada espécie tem um símile platônico que é uma luz imaterial de ordem horizontal, realidade permanente por excelência. A ciência das luzes é, portanto, a atividade das luzes por meio de suas diferentes combinações e relações que geram o movimento de descida até perder a sua luminescência e intensidade e que por isso mesmo desejam o retorno ao mundo das luzes.

O homem, por meio da luz de sua alma, livremente busca descobrir o véu que o separa de seu Senhor, por meio de um caminho de contemplação e de ascese. Esta busca está baseada no conhecimento direto e presencial, uma sabedoria que saboreia aquilo que deseja, cujos espaços se lhe apresentam por meio do mundo das formas veladas.

${ }^{296}$ Ibid., par. 279 (Corbin, pp.231-231; Walbridge \& Ziai, p.162). 


\section{CONCLUSÃO}

A nova abordagem filosófica de Suhrawardī está fundada em sua crítica à validade universal da lógica aristotélica da maneira que era corrente entre os filósofos árabes. Suhrawardī expressa seu desacordo com as ambiguidades e inconsistências que ele descobriu no peripatetismo árabe de seu tempo. Nesse ponto, como procuramos mostrar na Introdução deste trabalho, Suhrawardī não estava sozinho - muitos pensadores da mesma geração de Suhrawardī e nas gerações imediatamente anterior e imediatamente posterior a ele debateram sobre o alcance e os limites da lógica e da física peripatéticas corrente entre os árabes, propondo a construção de novos modelos epistemológico e cosmológico. Tais ambiguidades e inconsistências cobrem, para essa legião de críticos, praticamente, todo domínio da filosofia. Suhrawardī apresentou, em lógica, o caráter problemático do que se refere à predicação e à lei de identidade; em física, mostrou sua oposição à tese de que se poderia descrever e enumerar as inteligências separadas; Suhrawardī, por fim, é mais duro e mais rigorosamente sistemático no que se refere às bases do método de conhecimento aristotélico. Para ele, as coisas são conhecidas não por meio da dedução silogística, mas através de um conhecimento imediato e intuitivo. Os peripatéticos não haveriam apresentado sistematicamente o que é o modo intuitivo, nem haveriam feito discutir um processo epistemológico que poderia descrever a intuição primária ou o conhecimento imediato. O método de conhecimento proposto por Suhrawardī pretende construir uma teoria epistemológica unificada que descreve o conhecimento intuitivo de forma clara e coesa. O mais amplo impacto da filosofia de Suhrawardī aconteceu, portanto, na epistemologia. Suhrawardī postula, em seu Livro da sabedoria da iluminação, um método epistemológico novo e mais consistente, a "ciência das luzes"; nessa ciência as ambiguidades correntes entre os filósofos árabes são resolvidas. O Livro da sabedoria da iluminação postula inequivocamente a primazia de um modo imediato de conhecimento, temporalmente anterior a quaisquer inferências, que, em termos contemporâneos poderíamos dizer se tratar do conhecimento intuitivo nãoproposicional anterior à diferenciação diádica de sujeito-objeto.

A posição fundamental de Suhrawardī passou à história conhecida como "primazia da quididade"; entre os filósofos de origem persa - entre os quais a recepção 
da filosofia de Suhrawardī foi mais intensa e evidente - essa posição gerou um problema de longa data que dividiu as escolas filosóficas até os dias atuais. Trata-se também de uma questão de grande controvérsia. Aqueles que acreditam na primazia da existência consideram o próprio existente um construto intelectual; enquanto aqueles que defendem a primazia da quididade consideram a existência enquanto tal um construto intelectual. A posição de Suhrawardī é que se a existência for considerada um real fora do intelecto, então o real deve consistir em duas coisas - o princípio da realidade da existência e o existente da existência, o que requer uma referência fora do intelecto. Ora, seu referente fora do intelecto também deve consistir em duas coisas, que são subdivididas, e assim por diante infinitamente. Isso é algo, para Suhrawardī, manifestamente absurdo. Por conseguinte, a existência deve ser considerada como um conceito abstrato, um construto intelectual. Assim, pode-se inferir que o termo geral não é uma coisa fora do intelecto.

Em suma, Suhrawardīi ${ }^{297}$ contesta a posição aristotélica de que as leis da ciência sejam formuladas como proposições necessárias e sempre verdadeiras e universais. Através de um processo elaborado de argumentos, Suhrawardī estabelece a contingência futura (al-imkān al-mustaqbal) como um princípio epistêmico. Usando esse princípio e outros, argumenta ainda que, ao contrário da posição peripatética, as leis da ciência não gozam de universalidade.

É importante salientar que o Livro da sabedoria da iluminação é de natureza diferente das obras apologéticas e dos comentários compostos por teólogos dialéticos e não pode ser reduzida a uma philosophia ancilla theologiae. Alguns conceitos de Suhrawardī, como idrāk ("apercepção" ou "apreensão"); al-iḍāfa al-išrāqiyya (comparável ao "conhecimento não-predicável”); al-idrāk al-anā’iyya ("consciência de si"); mušāhada išrāqiyya (um modo de conhecimento intuitivo) e vários outros termos técnicos usados por Suhrawardī, que têm o seu paralelo e uso similar na filosofia ocidental, não podem ser confundidos, em seu significado, com os mesmos termos, de caráter eminentemente subjetivo, usados no sufismo.

${ }^{297}$ ZIAI, Hossein. "Illuminationism," in Encyclopedia of Philosophy [Macmillan Reference], Second Edition. Donald M. Borchert, Editor in Chief. Volume 4, New York: Thomson Gale, 2006, pp. 581-585, p. 583. 
Uma vez reconhecido o caráter eminentemente filosófico da obra de Suhrawardī, ao final deste trabalho, entendemos ser oportuno lembrar que, historicamente, o período entre a morte de Ibn Sīnā (429 H./ 1037 d.C.) e a morte de Ibn Rušd (595 H./ 1198 d.C.) marcou dois tipos distintos de atitude filosófica entre os filósofos árabes. Primeiramente, aparece a escola peripatética. Essa tradição se caracterizou pela estrutura e terminologia técnica oriundas da aproximação entre os textos aristotélicos com as principais obras de Ibn Sīnā, principalmente com o livro da Cura $(\breve{S i f a \bar{a}}$. O estudo da lógica, por exemplo, é dividido de acordo com o Organon de Aristóteles; a física está de acordo com a Física de Aristóteles; e o mesmo ocorre na metafísica com o livro homônimo de Aristóteles. Essa tradição filosófica continuou com os pupilos e discípulos de Ibn Sīnā, tais como Balmanyār e Abu'l-'Abbās alLawakarī $\overline{1}^{298}$ e com as numerosas glosas árabes e persas do Šifā e do Išārāt e outras obras de assuntos específicos do peripatetismo. Os problemas filosóficos dessa escola que se interpõem como pedras angulares da filosofia árabe são, em resumo ${ }^{299}$ : a posição da primazia da existência, a prioridade epistemológica dos conhecimentos adquiridos, o conhecimento do existencialmente necessário (wājib al-wujūd) dos universais no lugar dos particulares e a posição escatológica sobre a imortalidade da $\operatorname{alma}^{300}$.

Em segundo lugar e em oposição à escola peripatética destaca-se a figura de Suhrawardī ${ }^{301}$, construtor do iluminacionismo, um sistema filosófico distinto da

\footnotetext{
${ }^{298}$ MARCOTTE, Roxanne D. (2006) Preliminary notes on the life and work of Abu al-'Abba s alLawkari (d. ca. 517/1123). Anaquel de Estudios Arabes, 17 1: 133-157, pp. 135-140.

${ }^{299}$ ZIAI, Hossein. "The Illuminist Tradition”. In, The Routledge History of Islamic Philosophy. Edited by S.H. Nasr and Oliver Leaman. London: Routledge,.1995. Ch. 29, pp. 465-496, p. 465.

${ }^{300}$ Ibn Rušd, grande comentador de Aristóteles, pode ser considerado um terceiro ramo no desenvolvimento da filosofia árabe. Com efeito, Ibn Rušd esteve só; foi, efetivamente, pouco ou nada influenciado pelos desdobramentos peripatéticos pós-avicenianos e o impacto de sua interpretação de Aristóteles e de sua filosofia não fez escola e não teve repercussão entre os filósofos muçulmanos - mas sim entre os filósofos judeus e, por meio desses, no Ocidente latino-germânico.

${ }^{301}$ Importante percursor da crítica de Suhrawardī ao peripatetismo foi Ḥibat Allāh Abū al-Barakāt alBag̀dādī, um físico e filósofo judeu convertido ao islã, o mais valoroso crítico árabe da física de Aristóteles. Em sua principal obra, O probatório (al-Múctabar), Bag̉dādī desenvolve uma estrutura alternativa para a fundação aristotélica da filosofia, sobretudo no que se refere à epistemologia. Este livro está dividido em três sessões: lógica, física e metafísica. Ambos, Bag̉dādī e Suhrawardī, têm o mesmo fundamento epistemológico - a primazia da intuição. Do mesmo modo, após a morte de Suhrawardī, de forma similar à crítica ao peripatetismo, aparece a figura ímpar de Ibn ${ }^{\mathrm{c}}$ Arabī. Este, assim como Suhrawardī, frisa que a análise de uma coisa deve partir de algo existente - não de um construto intelectual - que passar a ser, a seguir, analisada pelo intelecto e no intelecto, em sua realidade intelectual. (EICHNER, Heidrun. "The Chapter 'on existence and non-existence" of Ibn
} 
filosofia peripatética (falsafa mašš $\bar{a}$ ’yya) de Ibn Sīnā e de uma teologia filosófica (kalām falsafì). Ao lado da escola peripatética, o iluminacionismo continuou a ser estudado depois da queda de Bagdá (1258 d.C.). Uma síntese entre iluminacionismo e peripatetismo foi buscada e atingida pelos filósofos iranianos dos sécs. X e XI H./ XVI e XVII d.C., no que, grosso modo, os historiadores do pensamento árabo-muçulmano chamam de "Escola de Ișfahān". O epíteto "iluminacionista" (ǐ̌s rāqū) é ainda hoje utilizado, especialmente no Irã, para caracterizar o método metafísico-epistemológico fundamentado na "ciência das luzes",302.

No tempo que se seguiu à morte de Suhrawardī, houve outros autores conhecidos por incorporar alguns princípios iluminacionistas em suas obras, mas que não podem ser qualificados puramente como "iluminacionistas". É o caso, por exemplo, do peripatético Nașīr al-Dīn al-Ṭūsī (m. 672 H./ 1274 d.C.), conhecido filósofo, astrônomo, matemático, jurista, estadista e teólogo xiita. Este escreveu um comentário ao al-ǐ̄āầt wa'-tanbīhāt de Ibn Sīnā, que se tornou um dos livros-texto padrão para o estudo da filosofia de Ibn Sīnā. Muitas gerações de filósofos no Irã vieram a descobrir a quintessência do peripatetismo aviceniano por meio desse comentário. Muhammad Ibn Zayn al-Dīn ibn Ibrāhīm Aḥsā’̀̄ (m. após 878 H./ 1479 d.C.), conhecido como Ibn Ab̄̄ Jumhūr Išrāqī Aḥsā'̄̄, está entre aqueles a quem se pode designar como "semi-iluminacionista".

O Livro da sabedoria da iluminação cresceu fora das reações a certos aspectos dos textos filosóficos árabes, a maioria deles associados com o corpus aviceniano. Os primeiros pensadores conhecidos por sua posição iluminacionista foram os estudiosos do séc. VII H. / XIII d.C., que comentaram os textos de Suhrawardī e também compuseram tratados filosóficos independentes que incluem posições específicas da corrente iluminacionista: Šams al-Dīn Muḥammad alŠahrazūrī, Sa ${ }^{c} d$ Ibn Manșur Ibn Kammūna e Quṭb al- Dīn al-Š̄īāzīina3.

Kammūna's al-Jadīd fi l-hikma trends and sources in a author's shaping the exegetical tradition of alSuhrawardī's Ontology" in LANGERMANN, Y. Tzvi (org). Avicenna and his legacy: a golden age of Science and Philosophy. Turnhout: Brepols Publishers, 2010, pp. 143-177, p. 144).

${ }^{302}$ Id. "The Illuminist Tradition", p. 466.

${ }^{303}$ Id., "Review of Shukri B. Abed, Aristotelian Logic and Arabic Language in Alfārāāi. Albany: State University of New York Press, 1991.Pp. 201.” In, International Journal of Middle Eastern Studies, Vol. 24, No. 4(Fall 1992), pp. 708-711. 
Šams al-Dīn Muḥammad Šahrazūrī, al-Išrāqū, ou seja, "o iluminacionista" (m. após 688 H./ 1288 d.C.), é o autor da bem conhecida história da filosofia Nuzhat al-arwāh wa rawudāt al-afrăh, bem como o autor do primeiro comentário principal do Livro da sabedoria da iluminação e das Intimações de Suhrawardi ${ }^{304}$.

$\mathrm{Na}$ história da lógica, da filosofia da matemática, da epistemologia e da metafísica merece destaque $\mathrm{Sa}^{\mathrm{c}} \mathrm{d}$ Ibn Manșūr Ibn Kammūna (m. 683 H./ 1284 d.C.). Este matemático, lógico, médico, historiador, filósofo e teólogo judeu ${ }^{305}$, contemporaneo de Šahrazūrī, escreveu um grande comentário, al-Talwīhăt, que ganhou o estatuto de livro didático entre filósofos iluminacionistas no Irã. Ibn Kammūnah, em toda a sua obra, se mostra influenciado por Suhrawardī e por Fahr alDīn al-Rāzī, e se propõe a dar procedimento ao trabalho fillosófico de ambos. Talvez o impacto mais significativo da filosofia iluminacionista possa ser visto na enciclopédia filosófica de Ibn Kammūna, al-Jadīd fi-l-hikma (A nova sabedoria ou Novum Organum). Infelizmente para o futuro da filosofia árabe, essa obra pouco ou nada impactou os filósofos seguintes. Há nessa obra tentativas ainda mais determinadas em elucidar os princípios filosóficos anti-aristotélicos que se originaram com Suhrawardī, assim como uma tentativa de construir uma filosofia iluminacionista da matemática e de se buscar um acordo entre Suhrawardī e Fah̆r al-Dīn al-Rāzīio6. Os escritos de Ibn Kammūna representam, pois, o mais genuíno legado da filosofia de Suhrawardī ${ }^{307}$.

\footnotetext{
${ }^{304}$ Id., "The Illuminist Tradition", pp. 468-469.

${ }^{305}$ HABIB BACHA, «Tanqīh al-abhat li-l-milal al-țalāt d'Ibn Kammūna », in Parole d'Orient, vol.2, nḲ1, 1971. pp. 151-162. No Tanqīh, Ibn Kammūnah, utilizando linguagem iluminacionista e fortemente influenciado por Faḩr al-Dīn al-Rāzī, estabelece uma profetologia e uma história do judaísmo, do cristianismo e do islã. Ibn Kammūna estabelece entre as três religiões uma comparação que, para a época, faz prova de grande objetividade. Após tratar filosoficamente sobre a profecia, Ibn Kammūna discorre sobre a história das três religiões proféticas, mostrando-se apologeta do judaísmo, cético em relação ao cristianismo e severo em relação ao islã. Com efeito, ao longo do texto, Ibn Kammūna revela simpatia por Jesus e admiração por Muhammad. Isso - assim como a sua metodologia teológica ser próxima à teologia $a \breve{s}$ ari - levou a se suspeitar sobre a conversão de Ibn Kammūna ao islã. Contudo, a defesa do judaísmo é tão forte e as críticas ao islã tão intensas que uma conversão do filósofo ao islã não parece ser razoável. Trata-se de um filósofo-historiador que pretende trabalhar "filosoficamente" a profetologia e mostrar filosófica e historicamente os aspectos proféticos e anti-proféticos do cristianismo e do islã e defender o judaísmo como verdadeira religião profética.

${ }^{306}$ EICHNER, Heidrun. "The Chapter 'on existence and non-existence" of Ibn Kammūna's al-Jadìd fì lhikma trends and sources in a author's shaping the exegetical tradition of al-Suhrawardī's Ontology", pp. 143-147.

${ }^{307}$ ZIAI, H. "The Illuminacionist Tradition", p. 469.
} 
Outro importante filósofo iluminacionista foi Quṭb al-Dīn Šīrāz̄̄in ${ }^{308}$ (m. 710 H./ 1311 d.C.), autor do comentário mais conhecido do Livro da sabedoria da iluminação, assim como do enciclopédico Durrat al-tāj, no qual procura comentar toda a obra de Suhrawardī. No entanto, em uma análise cuidadosa, o trabalho de Šīrāzī indica grandes empréstimos do trabalho de Šahrazūrī que anteriormente passaram despercebidos. Šīrāzī é uma figura mais conhecida na filosofia árabe do que Šahrazūrī, simplesmente porque ele é um dos primeiros filósofos pós-suhrawardianos no Irã com êxito em conciliar a filosofia aviceniana com a filosofia iluminacionista de Suhrawardī e a "gnose" filosófica ( ${ }^{\mathrm{i}}$ irfān) de Ibn "Arabī. Durrat al-tāj marcou o início de composições filosóficas em que a metodologia aviceniana e a metafísica de Ibn ${ }^{\mathrm{c}} \mathrm{Arab} \overline{1}$ estão harmonizadas com as teorias iluminacionistas da visão e da iluminação (epistemologia e psicologia). Esse trabalho foi também o primeiro texto filosófico em persa que aceitou a teoria do conhecimento de Suhrawardī. O trabalho de Šīrāzī também discute a ressurreição e a metempsicose (tanāsuh) dentro da interpretação dos seguidores da gnose filosófica de Ibn ${ }^{c}$ Arabī. Ao que parece, esse novo agrupamento de ideias foi um tipo de popularização da filosofia greco-árabe, sendo, entrementes, indicativo de uma tendência sincrética que culminou em Mulla Șadrā no séc. XI H./ XVII d.C.

A atividade filosófica entre os séc. VIII H./ XIV d.C. - séc. X H./ XVI d.C. é pouco conhecida. A maior parte dos trabalhos conhecidos nesse período sobre a filosofia de Suhrawardī indicam o impacto do sistema iluminacionista na mística muçulmana no Irã e na Índia e ilustram como os místicos fizeram uso do iluminacionismo. Qādi Jalal al-Dīn Ibn Muḥammad Sa d d al-Dīn Dawānī (m. 908 H./ 1501 d.C.) foi o autor da obra célebre em ética intitulado Ahlāqi jalālī e ocupou o cargo de vizir dos Āqquyünlü no nordeste da Pérsia. Seu comentário ao Hayākil al-nūr de Suhrawardī intitulado Šawākil al-hūr fì šarh hayākil al-nūr se tornou bem conhecido. Essa obra se inclui entre os trabalhos filosóficos de cunho sincrético e popular, que teve um forte impacto sobre a geração de pensadores de língua persa que se seguiram. De maneira semelhante, o indiano Ġiyat al-Dīn Manșūr Daštakī (m. 948 H./ 1541 d.C.), também escreveu um comentário ao Hayākil al-nūr, intitulado Išrāa $q$

${ }^{308}$ Ibid., p. 469. 
hayākil al-nūr li-kašf zulamāt šawākil al-gurūur. Não se trata de um importante trabalho teórico, mas de um importante testemunho do impacto de Suhrawardī entre os persas e indianos.

A filosofia eclética e mística influenciou diversos comentários, a maior parte dos quais escritos em persa, dos textos de Suhrawardī; um desses comentários foi composto por Muhammad Šarīf Niz̄ām al-Dīn al-Harawīi ${ }^{309}$, autor de uma significativa tradução persa com comentários do Livro da sabedoria iluminação, composto em 1008 H./ 1600 d.C. Uma das características mais importantes do comentário de Harawī é sua tentativa de comparar os princípios iluminacionistas com o sistema Advaita da sabedoria hindu. Essa obra, Anwāriyyah, é a única tradução persa com comentários do Livro da sabedoria da iluminação conhecida que sobreviveu, embora outros hajam sido compostos. Seu autor foi, provavelmente, influenciado pelo indiano Chištī Sufi, que também compôs um trabalho iluminacionista independente em persa, intitulado Sirāj al-ḥikma. Anwāriyya contém também comentários de seções selecionadas da segunda parte do texto árabe de Suhrawardī, sobre metafísica, cosmologia e outras experiências iluminativas de Suhrawardī - ignorando-se a primeira parte, a de lógica. O trabalho é típico da primeira tendência na interpretação iluminacionista pós-Suhrawardī e também é indicativo da falta geral de interesse por lógica e por metodologia filosófica nesse período. Ele enfatiza o lado fantástico da filosofia iluminacionista e inspira-se fortemente no comentário anterior de Quṭb al-Dīn Šīrāzī, adicionando também muitos exemplos extraídos de fontes místicas populares, especialmente a partir de Jalāl al-Dīn Rumī (604 H./ 1206 d.C. - 672 H./ 1274 d.C.). O trabalho de Harawī também pode interessar ao estudo da mística ou das relações entre islã e hinduísmo ou por sua tentativa global em apresentar uma interpretação mística do texto de Suhrawardī, o que, a nosso ver, não foi do interesse de Suhrawardī. Muitas vezes, quando comenta uma seção, Harawī adiciona algo de acordo com os modos de exibição realizada pelos mestres sufis, ou acrescenta algum argumento que dão suporte a pontos de vista próximos ao pensamento de diferentes mestres sufis.

Há, assim, desde o século VII H. /XIII d.C., uma dimensão dupla no legado da filosofia de Suhrawardī. De um lado estão Šahrazurī e Quṭb al-Dīn Šīrāzī; seus

${ }^{309}$ Ibid., p. 470. 
comentários sobre os textos de Suhrawardī - Šarḥ ḥikmat al-ǐ̌rāq, Šarḥ al-talwīhāat e o enciclopédico al-Šajara al-ilāhiyya — não só enfatizam os componentes simbólicos e distintos dos componentes anti-peripatéticos da filosofia iluminacionista, mas se aprofundam neles, estendendo-se demasiadamente para o lado fantástico e alegórico dos escritos de Suhrawardī. Por outro lado, aparece a figura de Ibn Kammūnah. Em seu Šarḥ al-talwīhăt, conjunto de comentários das Intimações de Suhrawardī, e no seu grande trabalho filosófico, Al-fadi fil-hikmah, bem como em suas obras mais curtas, tais como Risāla fi'l-nafs e al-Hikma, Ibn Kammūna enfatiza o lado puramente discursivo e sistematicamente filosófico do Livro da sabedoria da iluminação. Essas obras procuraram definir o simbolismo iluminacionista, as alegorias suhrawardianas e as inovações na lógica operadas por Suhrawardī e pelo teólogo-filósofo Faḩr al-Dīn alRāzī em termos da doutrina peripatético-aviceniana padrão e, assim, elaborando ainda mais o aspecto epistemológico da intenção original de Suhrawardī. Entretanto, foi a primeira tendência, apesar de menos filosoficamente rigorosa do que a de Ibn Kammūnah, que teve maior impacto na formação de opiniões sobre a filosofia entre os iluminacionistas. Šahrazurī pode ser considerado, dessa maneira, a origem de uma filosofia mística, religiosa e islâmica, que com Quṭb al-Dīn Šīrāzī passou a contar, cada vez mais, com apelo mais popular ${ }^{310}$.

A tradição iluminacionista e quase todos os outros aspectos da dimensão intelectual do islã foram revividos e reexaminados por autores muçulmanos de língua persa, no séc. X H./ XVI d.C., durante um dos períodos mais ativos e prolificamente frutuosos da história do pensamento universal. Assistiu-se uma renovação nos estudos teológicos entre os xiitas iranianos; com o apoio dos safávidas, os estudos teológicos se espalharam por todo o país. Como a maior parte dos teólogos xiitas iranianos estava embebida de filosofia e praticamente todos esses teólogos conheciam a tradição filosófica greco-árabe e, os principais entre eles, eram também comentadores de obras

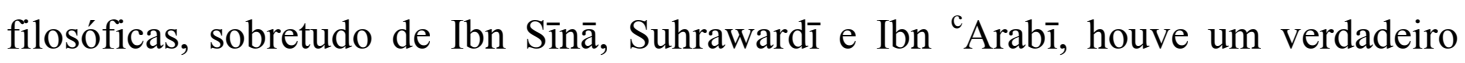
renascimento nos estudos filosóficos; esse renacimento teve por epicentro Ișfahān, na Pérsia central. As duas principais figuras desse renascimento cultural - Mīr Dāmād (com o epíteto poético "Išrāq") e Mulla Șadrā, cujas obras filosóficas estão repletas de

${ }^{310}$ Ibid., p. 473. 
terminologia iluminacionista - estudaram exaustivamente e fizeram uso da filosofia de Suhrawardī. A essa altura, praticamente todos os problemas que abrangiam o corpus filosófico árabe foram discutidos e rediscutidos tanto na perspectiva peripatética como na iluminacionista. Tornou-se prática comum a construção de argumentos para representar as duas posições em primeiro lugar, para depois demonstrar a superioridade de uma sobre a outra e tentar uma nova síntese entre as duas ou formular argumentos diferentes. Mīr Dāmād, por exemplo, procurou fazer uma releitura suhrawardiana do corpus aviceniano. Mulla Șadrā, por sua vez, ao tentar sintetizar peripatetismo e iluminacionismo ou ao procurar adaptar a filosofia ao kalām xiita, não teve escrúpulos em corrigir Ibn Sīnā ou Suhrawardī (ao defender, por exemplo, a criação temporal do cosmos ou a prioridade da existência sobre a quididade e a quididade entendia como construto intelectual, posições exatamente opostas às de Suhrawardīi) ${ }^{311}$.

O poeta, gramático, médico, filósofo, astrônomo, matemático e lógico Muḥammad Bāqir Ibn Šams al-Dīn Muḥammad (m. 1040 H./ 1631 d.C.), conhecido como Mīr Dāmād al-Išrāq, ou simplesmente Mīr Dāmād, é um dos poucos que pode ser contado como rigorosamente lógico entre os filósofos iluminacionistas, uma empresa que incluiria os seguidores imediatos de Suhrawardī, Ibn Kammūnah, bem como, em tempos mais recentes, Sayyid Muḥammad Kāzim ' Așșār. Mīr Dāmād se considerava um verdadeiro defensor da metodologia de Suhrawardī, combinando a filosofia discursiva (baht $\underline{\underline{\imath}})$ de Aristóteles e os métodos e princípios da metodologia do Šifa' de Ibn Sīnā com a sabedoria intuitiva ( $\underline{d} a w q \bar{\imath})$ platônica e a crítica à lógica aristotélica e a defesa da metafísica, cosmologia, física e psicologia tal qual são apresentadas por Suhrawardī no Livro da sabedoria da iluminação, cuidadosamente estipulado por Suhrawardī para ser a posição fundamental da filosofia iluminacionista. Em sua obra, se manifesta a intenção de Mīr Dāmād em construir uma estrutura filosófica holística baseada no conhecimento de si, que é a capacidade de combinar perfeitamente o exame dos dados sensíveis com as visões e as iluminações ${ }^{312}$.

\footnotetext{
${ }^{311}$ Ibid., pp. 471-472.

312 Ibid., p. 472.
} 
Mīr Dāmād ${ }^{313}$ foi talvez o filósofo mais significativo de sua época, o mais original e sistematicamente filosófico entre os pensadores da assim chamada "Escola de Ișfahān"314. Entretanto, a figura ímpar de Mīr Dāmād foi eclipsada pela de seu célebre aluno Șadr al-Dīn Muhammad Ibrāhīm al-Š̄īāzī, mais conhecido como Mulla $\operatorname{Ṣadrā~}^{315}$ (m. 1050 H./ 1640 d.C.). Autor de numerosos comentários ao Livro da sabedoria da iluminação de Suhrawardī, ao al-Hidāya fì l-ḥikma de Ațīr al-Dīn alAbharī e a partes da Šifā' de Ibn Sīnā, escreveu também várias obras originais. Entre essas, pode-se citar: A criação no tempo (hudūt), sobre $A$ ressurreição (al-hašr ), sobre a Atribuição do ser à essência, sobre A predestinação e o livre arbitrio, assim como Kitāb al-mašă $\bar{a}^{c}$ ir, Kitāb kasr aṣnām al-jāhiliyya e sua suma filosófico-teológica Kitāb al-hikma al-muta āliya também conhecida como Kitāb al-asfār al-arbac a (Livro das quatro viagens) ${ }^{316}$. Influenciado pela tradição místico-filosófica islâmica corrente no Irã e na Índia e pela gnose filosófica ( $\left.{ }^{c} i r f a ̄ n\right) ~ d e ~ I b n ~{ }^{c} A r a b \overline{1}$, Mulla Șadrā procurou sintetizar as correntes filosóficas peripatética e iluminacionista e a teologia xiita. Conseguiu estabelecer, assim, uma importante síntese teológico-filosófica que, em linhas gerais, molda o xiismo duodecimano e o pensamento iraniano até o presente.

Mais recentemente, o jurista, filósofo e teólogo xiita do século XIV H./ XX d.C., Sayyid Muḥammad Kāzim 'cAșsāâ, professor de filosofia islâmica na Universidade de Teerã até o seu falecimento (1396 H./ 1975 d.C.), também merece uma menção especial. Escreveu diferentes trabalhos de lógica iluminacionista, de espistemologia e de metafísica, retomando as ideias gerais do Livro da sabedoria da iluminação. Merece destaque o seu Waḥdat-i wujūd wa badā, o qual representa, ao

\footnotetext{
${ }^{313}$ Conhecido entre os seus contemporâneos como mu'allim-e țălit ("o terceiro mestre”). O primeiro haveria sido Aristóteles, e o segundo Fārābī. (En islam iranien : aspects spiritues et philosophique IVl'École d'Ispahan, l'École shaykie et de Douzième Imâm. Paris : Gallimard, 1972, p. 18).

${ }^{314}$ ZIAI, H. "The Illuminacionist Tradition", p. 472.

${ }^{315}$ Nascido em Širāz em 980 H./ 1571 ou 1572 d.C., Mulla Șadrā se estabeleceu em Ișfahān e seguiu seus estudos de tafsìr, hadit xiita e fiqh com Baha'ī 'Āmilī (m. 1031 H./ 1621 d.C.), gramática, medicina, matemática, lógica e astronomia com Mīr Dāmād e música, astronomia e teologia com Mīr Abū l-Qāsim Fendereskī (m. 1051 H./ 1641 d.C.). Este último tinha razoável conhecimento da filosofia mística islâmica desenvolvida na Índia, o que muito marcou Mulla Șadrā. Este retornou a Širāz para exercer o magistério em uma escola religiosa (madrasa), fundada pelo governador de Fārs. Morreu em Bașra quando se preparava para a sua sétima peregrinação (hajj) a Meca (cf. CORBIN, Henry. op. cit., pp. 54-68).

${ }^{316}$ FAKHRY, Majid. op. cit., pp. 331-332.
} 
que nos consta, o exemplo mais recente de uma discussão do princípio iluminacionista da realidade do existente (taškik fi $l$-wujūd $)^{317}$.

Com toda essa história, parece ser demasiado ousado falar que a filosofia árabe desapereceu com a morte de Ibn Rušd (595 H./ 1198 d.C.). Contemporaneamente a Ibn Rušd, muitos pensadores árabes procuraram reelaborar o patrimônio filosófico herdado das gerações passadas de falāsifa. Entre esses pensadores, se destaca Suhrawardī por ter conseguido estabelecer uma ruptura epistemológica no pensamento filosófico greco-árabe tal qual chegara até ele, especialmente no que se refere à tradição aviceniana ligada ao peripatetismo. Suhrawardī impôs uma metafísica que recuperou conscientemente a "sabedoria dos antigos" das mais diversas maneiras e procurou distingui-las bem. Reconheceu-se nele um esquema filosófico no qual a lógica aristotélica se viu formalmente questionada. Suhrawardī fez isso discutindo problemas próprios e comuns aos debates correntes entre lógicos, filósofos, teólogos e cientistas sobre os mais diversos temas, se concentrado, porém, no que se refere ao método de conhecimento. Suas elaborações nesse ponto podem, muito bem, inclui-lo entre os mais complexos e completos filósofos de seu tempo.

\footnotetext{
${ }^{317}$ Ademais, na história do iluminacionismo, é preciso considerar o possível impacto da filosofia de Suhrawardī a ocidente, especificamente sobre o desenvolvimento do pensamento judaico no Egito no séc. VIII H./ XIV. Isso é exemplificado pelo notável, embora pouco mencionada, paráfrase principal de seções importantes do Livro da sabedoria da iluminação composto pelo famoso vizir Lisān al-Dīn Ibn al-Hațīb em seu Rawḍat al-tac rïf bi'l-h̆ubb al-šarîf. Paul Fenton (Deux traités de mystique juive. Le Traité du puits et Le Guide du etachement [traduit du judéo-arabe, introduit et annoté par Paul B. Fenton et préface du professeur Georges Vajda]. Paris: Verdier, 1987, 334 pp.), em um capítulo de seu livro consagrado a "opinião dos antigos pensadores das luzes", cita textualmente o Kitāb hikmat ališrāa $q$. O rabino e teólogo Dāwūd Ibn Maymūn, liderança da comunidade judaica do Cairo no século XIV d.C., escreveu um Guia da separação, segundo Fenton, embebido pela linguagem iluminacionista da escola de Suhrawardī. Nessa obra, por exemplo, Dāwūd Ibn Maymūn oferece uma apresentação do conceito de iluminação, digna dos comentadores iluminacionistas do Livro da sabedoria da iluminação: “O 'iluminacionista' (išr $\bar{a} q \bar{l})$ designa o 'buscador da iluminação' (ǐsrāq), ou seja, aquele que deseja esclarecer sua alma e elucidar seu espírito pelos fulgorosos e sábios clarões da intelecção, preservando por meio da contemplação do mundo angélico, da evocação de Deus por uma memoração procedente de um ato de compunção e do aplicar-se na contemplação do mundo sacrossanto - um pensamento claro e sutil [...]. Essas luzes transbordarão em um coração puro na medida em que [o buscador] se eleva, por meio de etapas, às estações mais nobres e mais sublimes." (p. 212). Ver nota 63.
} 
Da leitura do Livro da sabedoria da iluminação, podemos apreender, ainda que em linhas gerais, o sistema epistemológico-metafísico de Suhrawardī. Assim, a título de resumo, podemos apresentar esse sistema da seguinte maneira:

\section{Lógica:}

Suhrawardī introduz em seu Livro da sabedoria da iluminação, em seu primeiro tratado, elementos de semântica, nos quais se discutem os problemas de significado, concepção, assentimento e a natureza da definição e da descrição da "realidade", entendida pelos iluminacionistas como quididade. O autor também discute sobre os acidentes, os universais (adotando, ao que nos parece, nominalista), os conhecimentos humanos inatos e não inatos e a noção de definição e seus elementos. Suhrawardī então prossegue com curtas discussões sobre as condições das provas, sobre a definição de proposições, suas classes e modalidades e inclui uma série de discussões sobre a contradição, conversão e alguns silogismos ("redução ao absurdo" e silogismos demonstrativos). Suhrawardī identifica alguns erros de lógica formal e material no uso da lógica corrente os peripatéticos árabes (um epítome em suas refutações sofísticas). Ele critica o entendimento dos peripatéticos sobre a negação, assim como as segunda e terceiras figuras do silogismo. Suhrawardī reduz todos os tipos de proposições para proposições afirmativas necessárias e discute algumas das diferenças entre os peripatéticos e a sua postura filosófica (iluminacionista) em relação ao número de sofismas. $\mathrm{O}$ autor revisita a teoria clássica das dez categorias que (como os estoicos) ele reduz a cinco: substância, qualidade, quantidade, relação e movimento; as quatro últimas são categorias acidentais. As categorias agora se tornam "graus de intensidade" (ou perfeição) de luz que os existentes possuem e que eles emitem, ao invés de ser meramente "construtos intelectuais". Como tal, o grau de intensidade luminosa (com seu corolário de "fraqueza") torna-se uma propriedade das substâncias, bem como dos acidentes.

- Definição: No Livro da sabedoria da iluminação, Suhrawardī rejeita as alegações de que é possível obter uma definição completa que poderia abranger todos os componentes essenciais necessários para levar ao conhecimento do que anteriormente era desconhecido e a necessidade de uma definição. Suhrawardī escreve que 
[...] assim, está claro que é impossível para um homem construir uma definição essencial no modo no qual quiseram os peripatéticos - uma dificuldade que seu próprio mestre [Aristóteles] admite. Portanto, obteremos definições só por meio das coisas que especificam por conjunção ou harmonia das partes $^{318}$.

Suhrawardī, por fim, insiste que uma definição deve enumerar, em algum tipo de fórmula unitária, todos os elementos essenciais da coisa descrita. O autor inclui, portanto, elementos de definição por extensão (enumeração dos membros de uma "classe") e da definição por intenção (enumeração de definir a propriedade ou as propriedades).

- Experiência direta: garantia da aquisição do conhecimento. $O$ conhecimento da realidade das coisas ocorre através da apreensão direta da luznatureza intrínseca (a coisa como ela é) de todos os existentes. O conhecimento direto ocorre através da "visão-iluminação", como um existente cognoscente percebe que o que deve ser definido se torna disponível para si através da autoconsciência. Nessa ocasião, quem conhece se torna diretamente consciente da realidade do que está para ser definido.

\section{Física:}

No Livro da sabedoria da iluminação, o autor lida principalmente com alguns princípios gerais da física, mas não entra em qualquer tipo de detalhe. Em sua metafísica (a ciência das luzes), ele consegue, no entanto, reconfigurar alguns elementos da física. Suhrawardī critica, por exemplo, a divisão peripatética dos existentes em matéria e forma, uma vez que o hilemorfismo se torna incompatível com o elemento fundamental da cosmologia de Suhrawardī, ou seja, com a luminosidade da realidade. Os existentes imateriais e os corpos materiais são compostos de vários graus de luz e permanecem como "entidades concretas unitárias". O mundo físico é composto por substâncias obscuras com acidentes obscuros, enquanto a autossubsistente magnitude parece substituir a matéria primeira que, como um número de noções tradicionais da física, torna-se um mero construto intelectual. Não é mais a

\footnotetext{
${ }^{318}$ Suhrawardī, op. cit., par. 15 (Walbridge \& Ziai, p.11).
} 
percepção da forma dos existentes, mas suas luzes constitutivas que se tornam o verdadeiro responsável pelo conhecimento.

\subsection{Psicologia:}

Em continuidade com a psicologia aviceniana, a alma continua sendo, para Suhrawardī, uma entidade imaterial, subsistente por si mesma, vivente, princípio do conhecimento, capaz de poder sobre o corpo; mas agora, para Suhrawardī, a alma é apresentada em termos de sua luminosidade. Uma relação de domínio e desejo é estabelecida entre a substância luminosa da alma e a substância tenebrosa do corpo. Entre os dois, o pneuma psíquico funciona como um intermediário que é capaz de receber imagens, símiles ou "ícones" de realidades suprassensíveis que refletem e se manifestam na alma.

A visão continua, assim como era, de maneira geral, entre os filósofos árabes, a ser o sentido externo mais importante. A teoria iluminacionista de Suhrawardī da visão está integrada e incorporada à sua teoria do conhecimento pela presença. $\mathrm{O}$ autor expressa uma crítica e uma rejeição a prevalentes teorias da visão "extramissiva" e "intramissiva", devido às implicações materialistas da impressão de imagens no substrato material do olho. Embora mediada por um órgão físico, a visão permanece essencialmente, na perspectiva iluminacionista, uma atividade da alma humana, através da qual a alma acessa diretamente a realidade das coisas vistas. A visão dos existentes materiais requer, primeiramente, um encontro "presencial", face a face, tanto daquilo com que percebe, o órgão físico, como da alma humana, com a coisa iluminada; segundo, a ausência de obstáculos entre o conhecedor e o conhecido, muitas vezes descrita em termos da tradição islâmica, como a ausência de véus, segundo a qual a alma torna-se iluminada pela luz (substancial ou acidental) da coisa; e finalmente, a presença da luz, condição indispensável para o estabelecimento de uma relação de conhecimento. A verdadeira visão não requer a presença e a transmissão das imagens, mas ocorre através da capacidade da alma para conhecer a realidade luminosa da coisa vista.

Suhrawardī critica a localização das faculdades internas em diferentes partes do cérebro, como a sua localização em um órgão material, o que novamente 
naturalizaria o processo de representação. As faculdades internas tornam-se agora funções da alma, agrupada em uma única faculdade responsável pela representação. $\mathrm{O}$ princípio da luz regente (nūr isfahbād) acessa as luzes, estabelece regras sobre a imaginação ativa e reflete sobre ele as luzes que recebe. A faculdade de representação percebe os particulares, enquanto a luz da decisão, o princípio de luz regente, garante a unidade da alma, percebe os universais e as entidades imateriais. Quanto à lembrança, Suhrawardī apresenta como a recuperação de imagens (ou conceitos), cuja existência encontra-se no mundo do memorial, acessível apenas à parte luminosa da alma. A iluminação se torna uma metáfora para o processo intelectivo. As relações iluminativas são estabelecidas entre os princípios ativos de luz e a alma humana. Considerando apenas uma parte (a racional) de luz regente da alma como imortal, Suhrawardī, observa, no entanto, a possibilidade, de que a faculdade imaginativa das almas que ainda não alcançaram a perfeição possam talvez sobreviver, algo que é necessário para se experimentar a retribuição divina e para o aperfeiçoamento das almas na vida futura. As esferas de éter e de Zamharir, ambas situadas abaixo da lua e associadas com o mundo dos elementos, são identificadas como possíveis substratos "pneumáticos" para as atividades póstumas das faculdades imaginativas daquelas almas. Suhrawardī tentou, assim, postular a existência de um reino escatológico independente com a ajuda do qual as percepções sensíveis podem ocorrer sob a forma de representações imaginárias; trata-se do mundo das imagens.

\subsection{Epistemologia:}

Como procuramos demonstrar, a epistemologia de Suhrawardī gira em torno de sua teoria do conhecimento "presencial" que é capaz de se alcançar através da apreensão intuitiva ou visão contemplativa, sem mecanismos intermediários. O conhecimento intuitivo fornece acesso às verdades a priori, que o conhecimento discursivo pode somente posteriormente validar através de demonstrações a posteriori.

Suhrawardī analisa as noções de apercepção e de autoconsciência e alude a um modo pré-lógico de percepção que permanece distinto da intelecção. $O$ autor discute a sensibilização primária da existência de si, a sua auto-identidade, o caráter imediato desse tipo particular de conhecimento e da consciência de individuação. Suhrawardī fornece, no Livro da sabedoria da iluminação, vários argumentos para 
demonstrar a existência de um tipo de conhecimento que é evidente, a priori e imediato sem necessidade de qualquer tipo de abstração e representação de imagens, seja através de uma imagem propriamente dita, uma noção intelectual ou um atributo de si. A percepção de si torna-se paradigmático do autoconhecimento como percepção sem intermediação, ou seja, um tipo não discursivo, não-conceitual e nãoproposicional do conhecimento que, no entanto, constitui um modo de saber distinto do conhecimento discursivo. $\mathrm{O}$ autoconhecimento proporciona mais uma ilustração do tipo de processo epistêmico que Suhrawardī considera ser o cerne do conhecimento intuitivo. A natureza sem intermediação desse processo caracteriza o autoconhecimento de almas e o conhecimento de almas de entidades suprassensíveis e os vislumbres da luz das luzes que se pode obter.

Aquilo que se pode perceber e apreender — a luz — não pode ser conhecido e apreendido discursivamente, mas apenas através de uma presença imediata ou da consciência de sua luminosidade. O conhecimento intuitivo, portanto, constitui o meio de se acessar a realidade luminosa.

Sua classificação de homens instruídos de acordo com seus respectivos méritos discursivos e intuitivos ${ }^{319}$ é revelador. A intuição ou percepção direta desempenha um papel predominante, mesmo para os profetas. $\mathrm{O}$ conhecimento profético conta com as funções da faculdade da imaginação, ou seja, sua função mimética e seu papel nas especificidades de verdades universais. A profecia se torna a experiência "direta" do mundo das luzes. Suhrawardī também introduz um reino independente e imaginário para considerar a capacidade de profetas e dos místicos que podem acessar a realidade das luzes, onde já existem formas imaginárias. Tais indivíduos são autorizados para receber e transmitir as mensagens divinas.

A intuição direta encontra-se no coração de profetologia de Suhrawardī, na medida em que os profetas tem conhecimento direto e presencial das verdades divinas - trata-se de uma aplicação elevada da tese do conhecimento presencial. Da mesma maneira, apenas os mais perfeitos sábios podem testemunhar, assim como os profetas, as verdades divinas, merecendo, então, a vice-regência de Deus, podendo viver como

\footnotetext{
${ }^{319}$ Ibid., par.5 (Corbin, p. 90; Walbridge \& Ziai, p.3).
} 
vice-regente de Deus de maneira pública ou em ocultação. Assim, os indivíduos que têm acesso à realidade das luzes podem ser investidos com a vice-regência de Deus. A alma é capaz de adquirir um poder luminoso e "teúrgico", mediado pela imaginação ativa que conferem facticidade às imagens e símiles que foram refletidos, em uma maneira semelhante ao espelho. Pode-se, assim, imitar e reproduzir formas que recebeu das luzes suprassensíveis. A faculdade de imaginação ativa, em seguida, projeta esse conteúdo sobre o "sentido comum", que fornece uma imagem sensível para essas realidades suprassensíveis que originalmente não possuíam.

\section{Metafísica}

Trata-se, como vemos na segunda parte do Livro da sabedoria da iluminação, do desenvolvimento de uma complexa ciência da inter-relação entre as luzes. A "luz" é o leitmotiv de sua metafísica, a estrutura de sua cosmologia e o coração da ciência sobre luzes e trevas que formam a realidade em seu todo. Alguns pontos se destacam na metafísica suhrawardiana:

\subsection{Existência e existente}

Suhrawardī criticou e rejeitou a distinção lógica, operada por Ibn Sīnā e corrente nos círculos avicenianos, entre quididade e existência, insistindo que o conceito de existência é adicionado à quididade in re, tal que a extensão geral do conceito de existência continua a ser um construto intelectual, não sendo algo real. Para Suhrawardī, conceitos como existência considerados a priori são construtos meramente intelectuais, com nenhuma realidade correspondente fora do intelecto.

A primazia da luz assinala uma mudança no entendimento da natureza da "essência" das coisas. Muitos filósofos árabes posteriores criticaram a tese da primazia da essência ou quididade de Suhrawardī, observando que tanto a quididade como a essência consideradas em si mesmas constituem também construtos intelectuais, como a existência. A posição do autor é, ao menos aparentemente - o que exigirá estudos mais aprofundados para investigar melhor a questão - ambígua. Essa posição, mesmo que ambígua, nos parece ser extremamente nominalista: a existência, a essência e a quididade (entendida como abstração, pois a quididade in re é a realidade concreta dos próprios existentes) são consideradas meros conceitos intelectuais; a realidade é 
redefinida com a nova primazia da luz. A luz e a quididade enquanto construto não podem, no entanto, ser sinônimos. A luz existe efetivamente: a luz é a quididade real dos existentes concretos; a luz não é uma abstração. Da mesma maneira, a luz não é idêntica à substância.

Mais tarde, Mulla Șadrā, seguindo nesse ponto específico Naṣīr al-Dīn alṬūsī (m. 672 H./ 1274 d.C), observou a confusão de Suhrawardī entre o conceito de existência e a realidade da existência e substituiu, em seu sistema metafísico, a noção de Suhrawardī de luz pela noção de existência, misturando a metafísica áraboperipatética de Ibn Sīnā e Țūsī com a cosmologia de Suhrawardī.

\subsection{Metafísica das luzes}

Enquanto a luz permanece sempre em si idêntica, sua proximidade ou distância com a luz das luzes determina a realidade de luz de todos os existentes. A luz opera através das atividades do domínio das maiores luzes "triunfais" ou "vitoriais", bem como o desejo das luzes inferiores das superiores, operando em todos os níveis e hierarquias da realidade. A realidade flui da luz das luzes e se desenrola através da primeira luz e todas as luzes subsequentes cujas interações exponenciais produzem todos os existentes. Como cada nova luz interage com outras luzes existentes, mais substâncias luminosas e obscuras são geradas. A luz produz luzes imateriais e substanciais, como inteligências imateriais (anjos), almas humanas e animais. A luz produz substâncias sombrias, como os corpos. A luz pode gerar tanto acidentes luminosos, como as luzes imateriais, raios ou luzes físicas, como acidentes obscuros, seja em luzes imateriais ou em corpos.

Suhrawardī, em sua metafísica, estabelece um princípio que pode ser considerado central. Trata-se do princípio da razão suficiente, chamado pelo autor de "princípio da mais nobre contingência", o qual afirma que nada pode existir sem uma causa de maior nível na realidade. Um segundo princípio é de origem aristotélica, trata-se da "impossibilidade de um infinito real e ordenado", que, com o primeiro princípio, garante que "não pode haver um número infinito de níveis entre os existentes e que deve haver um existente cuja factididade enquanto existente é 
necessária em si - existencialmente necessário (wājib al-wujūd) de Ibn Sīnā, a luz das luzes de Suhrawardī

Com a noção de intensidade da luz, Suhrawardī, então, desenvolve seu processo duplo de produção das luzes. Uma ordem vertical e outra horizontal de luzes imateriais puras estruturam sua metafísica. Da luz das luzes procede uma primeira ordem vertical de luzes: a luz das luzes produz uma primeira luz; dessa luz procede uma segunda luz e o limítrofe abrangente (isto é, um corpo etéreo); a partir da segunda uma terceira luz e o segundo limítrofe ou a esfera das estrelas fixas, e assim por diante. A primeira hierarquia vertical das luzes espelha o processo aviceniano-peripatético de fluir de inteligências. Suhraward̄̄, no entanto, aumenta o número de princípios ativos. As luzes triunfais e vitoriais agora são tão numerosas como as estrelas nos céus fixos. As luzes não estão limitadas às dez inteligências e são indeterminadas em número; elas não são, no entanto, infinitas.

A ordem vertical das luzes interage com uma ordem horizontal das luzes. Esta segunda ordem das luzes "dirigentes" incorpora, entre outras coisas, antigas angelologias (semíticas ordens angelicais e a mitologia mazdeana) e algo da doutrina platônica das formas. Cada uma dessas luzes horizontais torna-se um "senhor das espécies", subsistente por si, ou seja, um existente por si só luminoso e fixo de espécies, cuja função é análoga aos símiles platônicas na medida em que rege a espécie sob ele (em vez de ser um mero universal), como as espécies de corpos que movem as esferas celestes e toda a matéria sublunar, incluindo as almas humanas. Fora a interação das luzes horizontal e vertical, são gerados os corpos do mundo inferior. Estas luzes horizontais ou verticais estão todas estruturalmente interrelacionadas através do princípio do amor que as luzes mais baixas para as luzes superiores e o princípio da dominação que as luzes superiores exercem sobre as inferiores (101.12-103.31). As duas ordens dimensionais das luzes introduzem uma nova noção não linear de causalidade.

A multiplicação de entidades luminosas serve para aumentar a distância que há entre a luz das luzes e o mundo sublunar, proporcionando simultaneamente uma maior visão holística e lógica da realidade, já que a luz encontra-se em seu núcleo em todas as coisas. Noções de intensidade e gradação de luz, juntamente com noções de 
presença e automanifestação, são, portanto, centrais para a metafísica de Suhrawardī. A intensidade de luz corresponde ao grau de sua autoconsciência, tal que a autoconsciência da luz das luzes engloba toda a realidade (em termos de intensidade). Trata-se da mais alta aplicação do conhecimento presencial: pela presença luminosa em toda a realidade, a luz das luzes tem o conhecimento direto de todos os existentes. Dessa maneira, Suhrawardī consegue, filosoficamente, defender o conhecimento divino dos particulares.

\subsection{Mundo das imagens}

Suhrawardī introduziu a ideia de um "mundo imaginário", um quarto mundo independente, juntamente com o inteligível, o espiritual e o material. Este mundo das imagens, composto de sombras e corpos sutis, funciona como uma realidade intermediária entre o mundo da pura luz e o mundo físico das trevas, situado entre este mundo físico e o mundo das espécies e dos símiles platônicos (as luzes horizontais), talvez no limite inferior do mundo das almas.

O mundo das imagens em suspenso é o lugar da manifestação de entidades que de alguma forma possuem uma existência própria (alguns, antes de sua vinda à existência neste mundo). O mundo das imagens contém imagens que não estão incorporadas na matéria, um plano de fantasmas, das formas em espelhos, dos sonhos e dos mundos de admiração além do nosso próprio que a luz pode tornar existente. $\mathrm{O}$ mundo imaginário fornece o material para o milagroso. É onde visões dos sábios e dos místicos ocorrem, onde imagens escatológicas passam a existir, bem como onde se encontram elementos que não cabem convenientemente no esquema filosófico das formas em questão. Suhrawardī, no entanto, não desenvolveu sistematicamente esse conceito.

Procuramos ao longo do presente trabalho evidenciar que Suhrawardī conseguiu filosoficamente desconstruir, a partir da lógica, a filosofia peripatética, e conseguiu também filosoficamente, por meio da "ciência das luzes", construir um sistema metafísico-epistemológico, a saber: a "sabedoria da iluminação". Diante disso, nos parece exagerado, talvez - em certo ponto - até equivocado, se afirmar que as 
tradições persas pré-islâmicas e gnósticas hajam tido influência determinante e decisiva em seu pensamento, como afirmou grande parte dos estudos sobre Suhrawardī no século XX. Da mesma maneira, não nos parece ser relevante se, historicamente, Suhrawardī foi xiita ismaelita ou duodecimano (a probabilidade de que ele haja sido ismaelita ou influenciado diretamente pelo ismaelitismo nos parece pequena); tampouco importa, para o nosso trabalho, se historicamente ele foi sufi ou se se deixou influenciar pelo sufismo (hipótese razoável, permanecendo, no entanto, difícil determinar o grau de pertença de Suhrawardī ao sufismo); o fundamental, para a nossa pesquisa, é que, sem nenhuma dúvida, Suhrawardī foi especulativa e conceitualmente um faylasūf, herdeiro da filosofia e das ciências greco-helenísticas correntes entre os árabes. As tradições que Suhrawardī convocou para sustentar o seu sistema apresentado no Livro da sabedoria da iluminação se complementam harmonicamente, tendo um ponto alto em Platão, o sábio por excelência.

Com poucas exceções - como Max Horten, cem anos atrás, Anawati e Abū Rayyan, em meados do século XX, e Houssein Ziai, John Walbridge e Roxanne D. Marcotte $^{320}$, em tempos mais recentes -, os estudos sobre os textos árabes e persas de Suhrawardī não conseguiram reconhecer a sistematicidade filosófica da lógica, epistemologia, cosmologia e física de sua obra. O próprio Suhrawardī, que pretendeu apresentar um novo sistema epistemológico-metafísico, foi inadequadamente posto como autor de uma obra descrita por termos com pouco ou nenhum rigor filosófico, como, entre outros, "teosofia", "sabedoria oriental", "teosofia transcendental" e "sophia perennis". Suhrawardī foi um físico e um filósofo bem treinado, médico e matemático de formação, cujos trabalhos sobre lógica e os fundamentos da lógica, teorias cosmológicas, leis epistemológicas sistematizadas, discussões metafísicas, etc., demonstram sua intenção, a qual pode ser resumida em uma tentativa racional, entre outras coisas, de harmonizar o conhecimento intuitivo (al-hikma al-dawqiyya) com o conhecimento dedutivo (al-hikma al-bahtivyya).

\footnotetext{
${ }^{320}$ Autora de importantes e recentes trabalhos sobre Suhrawardī e seus contemporâneos. Seu artigo " L'aperception de soi chez Shihāb al-Dīn al-Suhrawardī et l'héritage avicennien » (Laval théologique et philosophique, volume $62, \mathrm{n}^{\circ} 3$, outubro de 2006) é um importante marco nos estudos suhrawardianos. Merece destaque também sua tese de doutorado em estudos islâmicos na Universidade McGill: Suhrawardī (d. 1191) and his Interpretation of Avicena's (d .1037) Philosophical Antropology, 2000, $355 \mathrm{pp}$.
} 
Do ponto de vista formal, o trabalho realizado até aqui nos abriu, assim, o seguinte panorama: deve-se destacar a amplitude da concepção de Suhrawardī tanto lógica como metafísica exposta no estudo apresentado. A primeira parte do Livro da sabedoria da iluminação, isto é, a lógica em três tratados, é a seção mais breve do livro, mas é, também, aquela que procura oferecer uma metodologia segura para a ciência de seu tempo, como foi exposto na segunda parte da obra, ou seja, na ciência das luzes, em cinco tratados.

Em sua lógica, Suhrawardī refuta, em seu primeiro tratado, a doutrina da “definição" usada pelos peripatéticos, pois esses acreditam que se pode conhecer a essência de uma coisa ao se listar o gênero e a diferença. Isso, para Suhrawardī, não é possível. Se se obtém sucesso é porque já se conhecia o gênero e a diferença; se não se conhecia, são palavras vazias. Também nunca se poderá estar plenamente certo de que todas as diferenças essenciais foram incluídas em uma definição. O conhecimento se dá, de maneira segura, apenas por meio do conhecimento direto. Desconstrói-se, assim, o núcleo da noção peripatética de ciência.

No segundo tratado da lógica, há um ataque ao silogismo modal peripatético. Suhrawardī procura a redução de todas as proposições a uma proposição universal, necessária e afirmativa, com modalidade, quantificação e negação incorporadas nos termos da própria proposição.

O terceiro e último tratado de lógica, por sua vez, está disposto em três seções. Nas duas primeiras há um levantamento de falácias comuns e da maneira de como evitá-las. Há aí crítica a argumentação tradicional corrente entre os peripatéticos. A terceira seção é central no livro e na obra, com refutações claras a específicas doutrinas, formando um compêndio dos desacordos entre o autor e o peripatetismo. Cada discussão é chamada de "juízo" (hukūma). O uso da seção sobre sofismas (sophismata) para discutir pontos fundamentais e questões disputadas em física e eventualmente, em metafísica, era algo comum entre os estudiosos de ciência natural contemporâneos do autor. Podemos ver, esquematicamente, na terceira seção do terceiro tratado de lógica: 
a) Estabelecimento de termos técnicos; mais do que estabelecer termos, procura discutir sobre substância e acidente, necessidade e contingência, causalidade, infinitudes possíveis e impossíveis. Ao criticar o peripatetismo corrente, Suhrawardī desenvolve pontos importantes que serão fundamentais em sua metafísica: (1) que "contingente" significa ser necessariamente causado por algo; (2) que uma causa é na realidade concreta anterior ao seu efeito, mas não temporalmente; (3) que uma causa pode ser composta e incluir condições e a remoção dos impedimentos e (4) que uma infinidade ordenada, simultânea e real é impossível, mas uma infinidade sem essas três propriedades é possível.

b) No primeiro juízo aparecem os construtos intelectuais (existência, necessidade, contingência, unidade, dualidade, cor em geral, privações, relações e substancialidade). Esses construtos não tem realidade concreta fora do intelecto. Os peripatéticos, impropriamente, reificaram tais ideias e criaram problemas insolúveis. No segundo juízo, é reiterado o criticismo em relação à definição e adicionado um breve ataque à doutrina das categorias.

c) O terceiro, quarto e quinto juízos são ataques ao hilomorfismo peripatético. $\mathrm{O}$ autor argumenta que o postulado de uma matéria distinta do corpo é desnecessário e que o corpo é apenas uma grandeza autossuficiente. Incluí-se também o ataque à noção peripatética de forma e substância segunda. Por fim, Suhrawardī passa pelas mais diversas questões da ciência natural, como, por exemplo, compressão e rarefação, calor, os elementos e a natureza das espécies. Refuta-se também o atomismo e a possibilidade do vácuo.

d) No sexto juízo, Suhrawardī se mostra de acordo com a doutrina da imortalidade da alma, mas ele acredita que a argumentação usada pelos peripatéticos para defender isso é inválida, principalmente por conta de suas inadequadas doutrinas de causalidade e contingência.

e) O sétimo juízo é sobre os símiles platônicos e, no caso de Suhrawardī, a relacionada questão de que se um simples efeito pode ter causas compostas. Ele se limita em responder aos argumentos peripatéticos tradicionais contra os símiles platônicos e defende a sua própria teoria de causas compostas, uma teoria que mais tarde será um alicerce necessário de sua versão da teoria dos símiles. 
f) $\mathrm{O}$ oitavo e nono juízos são críticas às teorias correntes sobre a visão. $\mathrm{O}$ autor argumenta com sua teoria da visão pela presença, segundo a qual a visão ocorre pela presença de uma coisa iluminada. Essa teoria da visão faz parte de sua teoria do conhecimento, a do conhecimento pela presença. O décimo juízo estende essa mesma teoria para os sons, criticando aa teoria de que os sons são redutíveis a vibrações no ar.

Breve e conciso, o conjunto da "lógica" está codificado, como podemos ver, em uma série de regras analítico-descritivas extraídas das críticas de Suhrawardī às doutrinas peripatéticas, cumprindo uma função determinante para levar a cabo o seu projeto: a redefinição do método de conhecimento. Suhrawardī frequentemente, nessa referida obra, faz alusão "aos outros livros que detalham melhor isso ou aquilo"; isso ocorre porque Suhrawardī tratou a temática de maneira mais exaustiva em seus escritos circunscritos ao caráter peripatético sobre lógica, física e matemática, presentes, por exemplo, no al-Talwīhāt, no Muqāwamāt ou no al-Mašāric wa 'lmuțārahāt. Trata-se de um percurso filosófico que Suhrawardī percorreu e que com o Livro da sabedoria da iluminação formam um compêndio. É nesse último livro que Suhrawardī desenvolve de maneira mais sistemática e orgânica o seu projeto filosófico e utiliza uma linguagem mais didática, precisa e específica.

Para Suhrawardī, a sabedoria discursiva, ou seja, aquela que os filósofos árabes desenvolveram até então, a partir, sobretudo de Aristóteles e da escola aristotélica, constitui uma filosofia legítima, oferecendo um método de conhecimento também legítimo - no entanto, insuficiente. Suhrawardī procurou colocar Aristóteles e sua filosofia dentro de um quadro sapiencial maior, cujo pai é Hermes e cujo pilar e guia é Platão. Esse quadro sapiencial oferece uma sabedoria intuitiva. Esta, por sua vez, consiste em uma teoria de conhecimento que possibilita o conhecimento da realidade pela presença, sem necessidade da definição, apenas da iluminação.

Para isso, como vimos, Suhrawardī focou sua crítica no conceito aristotélico de definição, mostrando sua insuficiência como modo de conhecimento, na medida em que a definição delimita a realidade, sem fundamentação nos existentes concretos. Suhrawardī procurou estabelecer uma teoria epistemológica que não se sustentasse unicamente na dedução. Justamente por isso, utilizou a lógica da hierarquia dos graus de luminescência para explicar a realidade, frente à limitação da ciência peripatética. 
A noção de contingência em Suhrawardī não pode ser expressa nos termos da lógica de configuração peripatética. Para Suhrawardī, toda a lógica demonstrativa corrente entre os peripatéticos está baseada na definição, o que faz com que os seus seguidores dêem prioridade aos entes lógicos em detrimento dos existentes concretos. Isso impede aos peripatéticos de captar o sentido lógico profundo da realidade concreta. Dado que o contingente pode tanto ser como não ser, dada também a impossibilidade do impossível e a necessidade do necessário, Suhrawardī os faz termos componentes de uma totalidade complementar e dinâmica, que deve ser expressa tanto horizontal como verticalmente. Entrementes, Suhrawardī se viu obrigado a rechaçar a metafísica dos seguidores dos peripatéticos, porque está fundamentada na noção de existência. Suhrawardī quis fundamentar sua metafísica naquilo que se manifesta e que, ademais, sempre se conhece pela experiência, pela presença. Assim, a demonstração do caráter não-real da "existência", da "contingência" e de todas as categorias aristotélicas, permite a Suhrawardī estabelecer um sistema de luzes, o qual consegue explicar que cada existente, para ser luz, depende de outro existente de uma ordem maior que converge na luz das luzes, a primeira e princípio de todas as luzes e o único existente absoluta e existencialmente necessário. Por conseguinte, ancorada na noção de conhecimento presencial, a sabedoria da iluminação constitui um novo método de conhecimento: a ciência das luzes.

Ao longo dessa pesquisa, seguimos a hipótese fundamental - que acreditamos ter conseguido comprovar - de que é de essencial importância a leitura do texto do Livro da sabedoria da iluminação por inteiro, com seus oito tratados dispostos em duas partes. Lamentamos que os três primeiros tratados que formam a primeira parte, a lógica de Suhrawardī, hajam sido omitidos na tradução francesa. Nossa hipótese fundamental é que, se não houver a apreensão da lógica do Suhrawardī, lógico de profissão, e da desconstrução que opera da filosofia peripatética, seu livro e seu sistema se converterá em uma obra mutilada que não permitirá avançar e compreender a reformulação, propósito e sentido da filosofia do lógico Suhrawardī. Seu sistema deu início a uma escola de pensamento e a um modo de se fazer filosofia. Trata-se do iluminacionismo, uma corrente de pensamento profícua no horizonte da história das ideias que se seguiu nos séculos seguintes. 
Não conhecemos, até o presente, outro trabalho acadêmico sobre Suhrawardī escrito em português. Entrementes, muito mais do que apresentar esse ilustre filósofo pouco conhecido, talvez quase ignorado, em língua portuguesa, procuramos contribuir modestamente na tarefa da redefinição da obra de Suhrawardī na história das ideias. Não obstante, em linhas gerais, algumas questões se colocam.

Uma das questões que nos são colocadas é verificar, com mais detalhe e maior precisão, qual o lugar do Livro da sabedoria da iluminação na obra de Suhrawardī. Ainda que tenhamos procurado responder a essa pergunta no Capítulo I deste trabalho, se faz necessário pesquisas sobre os demais livros de Suhrawardī para se ter uma visão mais completa do projeto filosófico do autor - e confirmar a tese de que Suhrawardī tinha um projeto filosófico efetivo.

Outra questão que merece um estudo mais aprofundado é saber qual o sentido e o alcance do Livro da sabedoria da iluminação. Nos Capítulos II e III buscamos responder essa questão, procurando aprofundar o que se refere à lógica (como se pode ler, principalmente, no Capítulo II). Não obstante, se faz necessário uma análise mais detalhada e profunda da ciência das luzes, colocando os seus cinco tratados em paralelo com outros textos que serviram de referência para Suhrawardī na elaboração de seu sistema metafísico - os de Ibn Sīnā, por exemplo.

Por fim, visto que a primeira parte da obra é fundamental na construção de sua metafísica, seria oportuno verificar de maneira mais aprofundada qual o lugar da lógica suhrawardiana na história da lógica. Ainda que tivéssemos sempre em mente essa questão na elaboração desta dissertação, estamos longe de uma resposta completa e não consideramos as conclusões desse trabalho, no que diz respeito a esse ponto específico, plenamente satisfatórias. Faz-se imperativo estudos sobre a primeira parte do Livro da sabedoria da iluminação e de outros escritos lógicos de Suhrawardī, se colocando em paralelo outros textos emblemáticos e contemporâneos de Suhrawardī, como os de Abū al-Barakāt al-Bag̉dādī, de Faḩr al-Dīn al-Rāzī ou de Ibn ${ }^{\mathrm{c}} \mathrm{Arab}$. Ademais, faz-se de grande importância estudos sobre a maneira pela qual se fez e se estudou lógica entre os filósofos iluminacionistas, seja entre os filósofos mais avessos a uma filosofia "técnica" - como Quṭb al-Dīn Šīrāzī e Mulla Șadrā, para citar os 
nomes mais famosos - seja entre os filósofos rigorosamente lógicos - como Ibn Kammūna e Mīr Dāmād, entre outros.

Tudo isso constitui objeto de pesquisas futuras. Suhrawardī foi um filósofo que merece, tanto ele como sua escola filosófica, um lugar de destaque na história do pensamento, não apenas árabe, mas universal. O lugar do fundador da escola iluminacionista e do iluminacionismo na história da civilização islâmica e na história da filosofia é algo que exige inúmeras outras investigações. É da intenção e da vontade do autor do presente trabalho prosseguir nessa caravana em um eventual doutorado. 


\section{BIBLIOGRAFIA}

\section{a. Bibliografia Principal:}

AS-SUHRAVARDÎ. "Hikmat al-Ishraq". Opera metaphysica et mystica 2 (ed. H.Corbin). Tehran : L’Institut Franco-Iranien, 1951.

SOHRAVARDÎ. Le livre de la Sagesse Orientale. Comentaires de Qotboddîn Shîrâzî e Mollâ Sadrâ Shîrâzî. Traduction et notes par Henry Corbin, établies et introduites par Christian Jambet. Paris: Éditions Verdier, 1986.

SUHRAWARDI. The Philosophy of Illumination. A new critical edition of the text of Hikmat al-Ishraq, with English translation, notes, commentary and introduction by John Walbridge and Hossein Ziai. Provo, UT: Brigham Young University Press, 1999.

\section{b. Bibliografia Secundária:}

AL-FĀRĀBĪ. Livro dos princípios das opiniões dos habitantes d'A cidade excelente (introdução, tradução e notas de Miguel ATTIE FILHO). Tese de livre-docência, Universidade de São Paulo, 2010.

AMINRAZAVI, M. “The Significance of Suhrawardī's Persian Sufi Writings in the Philosophy of Illumination" in LEWISOHN, L. (ed.) The Heritage of Sufism (volume I): Classical Persian Sufism from its Origins to Rumi (700-1300 d.C.). Oxford: Oneworld.

. "The Status of Suhrawardī Studies in the West". Journal of Religious Thought: a quarterly of Shiraz University. New York: Spring, 2004.

ANAWATI, C.G., « La notion de wujud dans le Kitab Al-Mashari' wa'l-Mutarahat de Suhrawardi» Memorial Shihab al-Din Suhrawardi a l'occasion de Huitième Centenaire de as mort, Cairo, 1974.

ANAWATI, C.G. \& GARDET, L. Introduction à la théologie musulmane - essai de théologie comparé. Paris: Vrin, 1948. 
. Mystique musulmane, - aspects et tendences, experiences et techniques.

Paris: Vrin: 1961.

ARNALDEZ, R. Fakr al-Dîn al-Râzî, commentateur du Coran et Philosophe. Paris: Vrin, 2002.

- Les Sciences Coraniques: Grammaire, droit, théologie et mystique. Paris : Vrin, 2005.

ARISTÓTELES. De anima. (tradução, apresentação e notas por Carlos Humberto GOMES). Lisboa: Edições 70, 2001.

AS-SUHRAVARDÎ. Opera Metaphysica et mystica I. Istambul: Maarif matbaasi, 1945.

. L'Archange empourpré : quinze traités et récits mystiques.

Traduits du persan et de l'arabe, présentés et annotés par Henry Corbin Paris: Fayard, 1976.

- Ouvres Philosophiques et Mystiques III. Teerã : Académie Imperiale de Philosophie, 1977.

. The Book of Radiance (Partaw Nameh), A parallel English-Persian

text, edited, translated, with an introduction by Hossein Ziai. Costa Mesa: Mazda Publishers, 1998.

ATTIE Fo, M. O Intelecto em Ibn Sinnā (Avicena). 1. ed. São Paulo: Ateliê, 2007.

. Inteligência e Metafísica em Ibn Sina (Avicena). São Paulo: Attie

Editora, 2012.

BELO, C. Chance and Determinism in Avicenna and Averroes. Leiden: Brill, $2007 .$.

CARRA DE VAUX. «La Philosophie Illuminative (Hikmet el-ichraq), d'après Suhrawerd Meqtoul » (1900) in SEZGIN, Fuat. As-Suhrawardī Shihābaddīn Yahyyā ibn Habash. Frankfurt am Main: Institute for the History of Arabic-Islamic Science at the Johan Wolfgang Goethe University, 2000. 
CORBIN, H. En Islam iranien: aspects sperituels et philosophiques, Tome II Sohrawardī et les Platoniciens de Perse. Paris: Gallimard, 1971.

. Histoire de la philosophie islamique. Paris: Enciclopédie de la Pléiade, 1974.

FAKRY, M. Histoire de la philosophie islamique. (tradução do inglês por Marwan NASR). Paris: Éditions du Cerf, 1986, p.323.

CRUZ-HERNÁNDEZ, M. Historia del pensamiento en el mundo islámico. 1. Desde los orígenes hasta el siglo XII en Oriente. Madri: Alianza, 2000.

. La estructura místico-metafísica del saber de la Alborada

(Hikmat al-Ishrâq) de Sihab al Din Yahia Suhrawardî, al saij al-Ishrâq, al maqtul wal-Shahid (549/1154-558/1191) in Homenaje a P. Sainz Rodríguez. Madri: 1986, Vol. 5, pp.167-171.

EICHNER, Heidrun. "The Chapter 'on existence and non-existence' of Ibn Kammūna's al-Jadìd fì l-hikma trends and sources in a author's shaping the exegetical tradition of al-Suhrawardī’s Ontology" in LANGERMANN, Y. Tzvi (org). Avicenna and his legacy: a golden age of Science and Philosophy. Turnhout: Brepols Publishers, 2010.

ELAMRANI-JAMAL, A. Logique aristotélicienne et grammaire árabe. Paris : Vrin, 1983.

GARDET, L. “À propos de l'ishrāq de Suhrawardī : valeurs speculatives et experience vécue” In HOURANI, G.F. Albany: State University of New York Press, 1975.

. «Suhrawardī, shaikh al-Ishrāq et la culture musulmane » in MADKOUR, I. Études Philosophiques. Gebo, 1974.

GIMARET, D. « Boudha et les boudhistes dans la tradition musulmane ». Journal Asiatique, 1969.

GÓMEZ NOGALES, S. «Suhrawardī et sa signication dans le domaine de la philosophie » in SALOM, P. (ed.) Mélanges d'Islamologie - Volume dedié à la 
mémoire de Armand Abel par ses collègues, ses élèves et ses amis. Leiden : E.J. Brill, 1974.

GOICHON, A.-M. Lexiquue de la langue philosophique d'Ibn Sinā (Avicenne). Paris, 1938, p.159.

. "O Pretenso Esoterismo de Avicena no Relato Hayy IbnYaqzan" (tradução e introdução de Christiane DAMIEN). Tiraz Revista de Estudos Árabes e das Culturas do Oriente Médio. São Paulo: Programa em Língua, Literatura e Cultura Árabe - USP.

GRIL, Denis. « Ibn ${ }^{\mathrm{c}}$ Arabī et les catégories » in PERLER, Dominik \& RUDOLPH, Ulrich (org) Logic und Theologie : das Organon im arabischen und im lateinischen mittelalter. Leiden: Brill, 2005

GUTAS, Dimitri. Avicenna and the Aristotelian tradition - Introduction to reading Avicenna's philosophicalworks. Leiden: E. J. Brill, 1988.

HADOT, Ilsetraut. Simplicius, Commentaire sur le Manuel d'Epictète. Paris : PUF, 2001.

HABIB BACHA, «Tanqīh al-abhat li-l-milal al-țalāt d'Ibn Kammūna ». Parole d'Orient 2, 1971.

HORTEN, M. „Die Philosophie der Erleuchtung nach Suhraward̄̄ (1191)“ in SEZGIN, Fuat. As-Suhraward̄̄ Shihābaddīn Yahyā ibn Habash. Frankfurt am Main: Institute for the History of Arabic-Islamic Science at the Johan Wolfgang Goethe University, 2000.

IBN SĪNĀ. Al-Šifā, VI, al-Nafs. Editados por G. Anawati e S. Zāyid, sob direção de Ibrāhīm Madkūr. Cairo: al-Hay’ a al-mișriyya al-- ‘̄āmma lil-kitāb, 1390/1975. Livre des Directives et Remarques (introduction, traduction et notes par A.-M. Goichon). Beirute-Paris: Comission Internationale pour la traduction des chefs d'ouvre et Librarie philosophique J. Vrin, 1951.

. Le Récit de Hayy ibn Yaqzān - Comenté par des textes d'Avicenne (Tradução do árabe, introdução e notas de A.-M. GOICHON). Paris : Desclée de Brower, 1959. 
- Livro da alma, tradução do árabe, introdução, notas e glossário por Miguel Attie Filho, prefácio de Carlos Arthur Ribeiro do Nascimento. São Paulo: Globo, 2011, p. 260.

KRAUS, Paul. « Les “controverses” de Fakroddīn al-Rāzī». Bulletin de l'Institut d'Égypte XIX, 1937

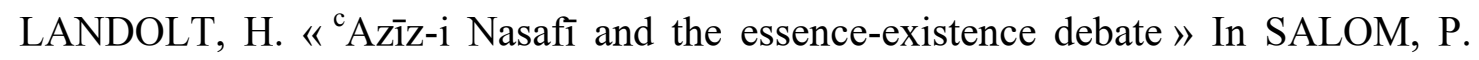
(ed.) Mélanges d'Islamologie - Volume dedié à la mémoire de Armand Abel par ses collègues, ses élèves et ses amis. Leiden : E.J. Brill, 1974.

. «Les idées platoniciennes et le monde de l'image» in DE SMET, Daniel; SEBTI, Meryem \& DE CALLTA, Godefroid. Miroir et savoir: la transmission d'un thème platonicien, des Alexandrins à la philosophie arabomusulmane. Louvain-la-Neuve : Leuven University Press, 2008.

. «Mystique Iranieen: Suhrawardī shaikh al-Ishrāq (549/1155587/1191) et ' Ayn al-Quzāt-i Hamadānī (492/1098-525/1131) » In Recherches en Spiritualite Iranienne (Recueil d'articles). Teerã : Presses Universitaires d'Iran \& Institut Français de Recherche en Iran, 2005.

- "Suhrawardī between philosophy, sufism and ismaelism: a reappraisal" In Recherches en Spiritualite Iranienne (Recueil d'articles). Teerã : Presses Universitaires d'Iran \& Institut Français de Recherche en Iran, 2005.

. «Suhrawardī’s “Tales of Initiation” » In Recherches en Spiritualite

Iranienne (Recueil d'articles). Teerã : Presses Universitaires d'Iran \& Institut Français de Recherche en Iran, 2005.

MAÏMONIDE, D. \& MAÏMONIDE, O. Deux traités de mystique juive. (traduit du judéo-arabe et introduit par Paul FENTON). Paris : Verdier, 1987.

MARCOTTE, Roxanne D. Suhrawardī (d. 1191) and his Interpretation of Avicena's (d.1037) Philosophical Antropology. Tese de doutorado (Universidade McGill), 2000. 
. «L'aperception de soi chez Shihāb al-Dīn al-Suhrawardī et l'héritage avicennien ». Laval théologique et philosophique, volume 62, n 3, 2006. . "Preliminary Notes on the Life and Work of Abū al- ${ }^{\mathrm{c}}$ Abbās alLawkarī (d. ca. 517/1123)”. Anaquel de Estudios Árabes. Madri: 2006.

- "Reason ( $\left.{ }^{c} a q l\right)$ and Direct Intuition (mushāhada) in the Works of Shihāb al-Dīn al-Suhraward̄̄ (d. 587/1191" in LAWSON (ed.) Reason and inspiration in islam: theology, philosophy and mysticism in muslim thought. Essays in Honour of Hermann Landolt. Londres: The Institute of Ismaeli Studies, 2005.

MASSIGNON, L. Recueil de textes inédits concernant l'histoire de la mystique en pays d'Islam. Paris : 1929.

MEHREN, Traités mystiques de Aboû Alî al-Hosain b. Abdallâh b. Sinnâ ou Avicenne, texte arabe accompagne de l'explication en français par M.A.F. MEHREN. Leyden : E. J. Brill, 1888-99 [reimpresso (4 fascículo em 1 único volume) em Leiden: A.P.A, 1979], fasc. I.

MICHOT, Jean. «La réponse d'Avicenne à Bahmanyâr et al-Kirmâni. Présentation, traduction critique et lexique arabe-français de la Mubâhatha III »Mu. 110, 1997. . «L'eschatologie d'Avicenne selon F. D. Rāzīı, Révue Philosophique de Louvain 87 (1989).

MONNOT, Guy. «La Transmigration et l'inmortalité». Melanges de l'Institut Dominicain d'Études Orientales (MIDEO) 14 (1980).

. Penseurs musulmanes et religions iraniennes. Paris: Vrin, 1974.

NASR, S. H. "The spread of the Illuminationist school of Suhrawardī". The Islamic Quaterly, Volume XIV, Number 3.

NETTON, I. R. "The Neoplatonic Substrate of Suhrawardī's Philosophy of Illumination : Falsafa as Tașawwuf » in LEWISOHN, L. (ed.) The Heritage of Sufism (volume I): Classical Persian Sufism from its Origins to Rumi (700-1300 d.C.). Oxford: Oneworld. 
. "Suhrawardī’s Heir? The Ishrāqī Philosophy of Mīr Dāmād". in LEWISOHN, L. \& MORGAN, D. (ed.) The Heritage of Sufism (volume III): Classical Persian Sufism (1501-17500 d.C.) The Safavid \& Mughal Period. Oxford: Oneworld.

PINÈS, S. « La conception de la conscience de soi chez Avicenne et chez Abu'lBarakāt al-Baghdādī », Archives d'Histoire doctrinalle et littéraire du Moyen-Age 21, 1954.

. «La "Philosophie Orientale" d'Avicenne et sa polemique contre les bagdadiens » in The collected works of Schlomo PINÈS, Volume III : Studies in the History of Arabic Philosophy. Jerusalém: The Magnes Press \& The Hebrew University, 1996.

- "Some distinctive Metaphysical Conceptions in Themistius' Commentary on Book Lambda and Their Place in the History of Philosophy", Aristotle Werk und Wirkung, J. Wiesner (ed.), vol. 2. Berlim: De Gruyper.

RISVI, S. H. “'Au-delà du Miroir' or Beyond Discourse and intuition : pedagogy and epistemology in the philosophy of Mullā Șadrā Šīrāzī [ca. 1571-1635]” In Miroir et savoir: la transmission d'un thème platonicien, des Alexandrins à la philosophie arabo-musulmane. Louvain-la-Neuve : Leuven University Press, 2008.

ROUHOL-AMIN, Irandokht. L'interpretation de Sohrawardi par Molla Sadra. Mémoire de Maîtrise (Philosophie), Université de Paris-Sorbonne, 1972.

SAATTCHIAN, Ahmad. L'experience mystique de Sohrawardi. Thèse de doctorat d’État (Philosophie) Université de Bourgogne, Dijon, 1989.

SEBTI, Meryem. Avicenne. L'âme humaine. Paris : PUF, 2000.

SHAHRASTANI. Livre des Religions et des Sectes, vol. I (Traduction avec introduction et notes par Daniel GIMARET et Guy MONNOT). Leuven : Peeters/Unesco, 1988.

. Livre des Religions et des Sectes, vol. II (Traduction avec introduction et notes par Jean JOLIVET et Guy MONNOT). Leveun : Peeters/Unesco, 1993. 
STREET, T. "Fuhraddīn Ar-Rāzī’s critique of Avicennan Logic" in PERLER, Dominik \& RUDOLPH, Ulrich. Logik und Theologie: das Organon im Arabischen und im lateinischen mittelatter. Leiden-Boston: Brill, 2005.

VALLAT, P. Farabi et l'École d'Alexandrie: Des premisses de la connaissance à la philosophie politique. Paris : J. Vrin, 2004

WALBRIDGE, J. "A sufi Scientist of the Thirteenth Century: The Mystical Ideas and Practices of Quṭb al-Dīn Shīrāzī” In LEWISOHN, L. (ed.) The Heritage of Sufism (volume I): Classical Persian Sufism from its Origins to Rumi (700-1300 d.C.). Oxford: Oneworld.

. "Al-Suhrawardī on Body and Extension: An Alternative to Hylomorphism from Plato to Leibniz". In LAWSON (ed.) Reason and inspiration in islam: theology, philosophy and mysticism in muslim thought. Essays in Honour of Hermann Landolt. Londres: The Institute of Ismaeli Studies, 2005.

. The Leaven of the Ancients. Suhrawardî and the Heritage of the Greeks. Albany: SUNY, 1999.

- The wisdom of the Mystic East. Suhrawardî and the Platonic Orientalism. New York: SUNY, 2001.

- The Science of Mystic Lights. Qutb al-din Shirazi and the Illuminationist Tradition in Islamic Philophy. Cambridge: Harvard University Press, 1992.

comentário bibliográfico de M. Amin Razavi, Suhrawardî and the School of Illumination, publicado no International Journal of Middle East Studies 30, $\mathrm{n}^{\circ} 4,1998$.

ZIAI, H. "Al-Suhraward̄̄, Shihāb al-Dīn” em Encyclopedia of Islam, Second Edition, (A.30).

. Anwāriyya: Early 17th century Persian commentary on Suhrawardī's Philosophy of Illumination, by MuHammad Sharīf al-Harawī. Edited with 
Introduction and Notes by Hossein Ziai. Tehran: Amir Kabir, 1979. Pp.xxx, 261. (Second edition, Tehran: Amir Kabir, 1985. See also below, C.28).

Knowledge and Illumination: A Study of Suhrawardī's Hikmat alIshrāq. Brown Judaic Studies 97; Atlanta: Scholars Press, 1990. Pp. xi, 223. (A.12) . Knowledge and Illumination: A Study of Suhrawardī's Hikmat alIshrāq. Brown Judaic Studies 97; Atlanta: Scholars Press, 1990. Pp. xi, 223. (A.12) - Shams al-Dīn Muhammad Shahrazūrī’s Shar Hikmat al-Ishrāq, Commentary on the Philosophy of Illumination. Critical edition, plus English and Persian Introductions, Notes and Indexes. Cultural Studies and Research Institute, no. 736: Tehran, 1993.

. Shihab al-Din Suhrawardi: founder of the Illuminationist school. In LEAMAN, O.; NASR, S. H. (eds.) History of Islamic Philosophy. London: Routledge, 1996.

. "Source and Nature of Authority: A study of Suhrawardī's Illuminationist Political Doctrine." In, The Political Aspects of Islamic Philosophy, edited by Charles Butterworth. Cambridge: Harvard University Press, 1992. . The illuminationist Tradition. In LEAMAN, O.; NASR, S. H. (eds.) History of Islamic Philosophy. London: Routledge, 1996.

\section{c. Bibliografia complementar:}

ANAWATI, C. G. Les grands problems de la Théologie musulmane. Paris: PUF, 1967. . Études de philosophie musulmane. Paris: J. Vrin, 1974.

ARISTÓTELES-PSEUDO. Teologia. Tradución y notas Luciano Rubio. Madri: Paulinas, 1978.

ARNALDEZ, R. À la croisée des trois monothéismes. Paris : Albin Michel, 1993. 
ATTIE F ${ }^{o}$, M. Falsafa: a filosofia entre os árabes. São Paulo: Palas Athenas, 2002. - Os sentidos internos em Ibn Sīnā (Avicena). Porto Alegre: EDIPUCRS, 2000.

BADAWI, A. Histoire de la philosophie en Islam. Paris: J. Vrin, 1972. . La transmission de la philosophie grecque au monde arabe. Paris: J. Vrin, 1987. - Quelques figures et themes de la philosophie islamique. Paris: Maiosonneuve et Larose, 1979.

BAFFIONI, C. I Grande Pensatori dell'Islam. Roma: Edizione Lavoro, 1996.

BAUSANI, A. L'Enciclopedia dei Fratelli della Purità. Nápoles: Instituto Universitario Orientale, 1978.

BLACHÈRE, Regis. Introduction au Coran. Maisonneuve \& Larose, 1991.

BOUMRANE, C. Le problème de la liberté humaine dans la pensée musulmane (Solution mu'tazilite). Paris : Vrin, 1978.

BOUYGES, M. «Roger Bacon a-t-il lu des livres arabes ?» Archives d'Histoire doctrinalle et littéraire du Moyen-Age 5, 1931.

BRAGUE, Rémi. Au moyen du Moyen Age : Philosophies médiévales en chrétienté, judaïsme et islam. Paris : Éditions de La Transparence, 2006.

CARRA DE VAUX, B. Les penseurs de l'Islam. Paris: Félix Alcan, 1900.

CORBIN, H. Avicenne et le récit visionnaire, Paris: Verdier, 1999.

.Corps spirituel et Terre céleste: de L'Iran mazdéen à l'Iran shî'ite. Paris : Buchet/Chastel,1979.

.Philosophie iranienne et philosophie comparée. Paris: Buchet/Chastel,1979. 
.L'Alchimie comme art hiératique. Paris : L'Herne, 1986.

.Le paradoxe du monothéisme. Paris : 1'Herne, 1981.

.L'homme de lumière dans le soufisme iranien. Paris: Éditions

«Présence », 1971.

.L'Imagination créatrice dans le soufisme d'Ibn'Arabî, $2^{\mathrm{e}}$ éd.,Flammarion, 1977.

.L'imam caché, Paris: L'Herne, 2003.

.Temps cyclique et gnose ismaélienne, Berg International, 1982.

CORTABARRIA, P. A. «L'étude des langues au moyen âge chez les Dominicains, Espagne, Orient. Raymond Martin » MIDEO 10. Cairo : Dār al-Maaref, 1970.

DE LIBERA, A. A filosofia medieval. Rio de Janeiro: J. Zahar, 1990. . Pensar na Idade Média. São Paulo: Ed. 34, 1999.

GARDET, L. Études de philosophie et mystique compares. Paris: J. Vrin, 1972. . La pensée religieuse d'Avicenne. Paris: J. Vrin, 1951. . Les grands problems de la théologie musulmane: Dieu et la destine de l'homme. Paris: J. Vrin, 1967. . L'Islam, religion et communauté. Paris: Desclée de Brower, 1967.

GILLIOT, Claude. «Exégese, Langue et théologie en islam. L'exégèse coranique de Tabari ». Études Musulmanes XXXII. Paris : Vrin, 1990. . "La théologie musulmane en Asie Centrale et au Khorasan ». Arabica: Journal of Arabic and Islamic Studies XLIX. Leiden: Brill, 2002.

GILSON, E. A filosofia na Idade Média. São Paulo: Martins Fontes, 1995. . História da filosofia cristã. Rio de Janeiro: Vozes, 1995. 
. «Les sources greco-arabes de l'augustinisme avicennisant». in Archives d'histoire doctrinale et littéraire du Moyen Age. Paris : J. Vrin, 1929.

.Por que Santo Tomás criticou Santo Agostinho? - Avicena e o ponto de partida de Duns Escoto. São Paulo: Paulus, 2010.

GIMARET, Daniel. Les noms divins en Islam. Paris : Éditions du Cerf, 2007.

JEAN DAMASCENE, Écrits sur l'Islam (Présentation, Commentaires et Traduction par Raymond Le Coz). Paris: Éditions du Cerf, 1992.

JUBRAN, S. A. A. C. Hierarquia dos Povos. São Paulo: Amaral-Gurgel Editorial, 2011.

KELLENS, J. Zoroastre et l'Avesta ancien. Leuven: Peeters: 1991.

KÜNG, H. El Islam : Historia, Presente, Futuro. Madri: Trotta, 2006.

LAOUST, Henri. «Les premières professions de foi hanbaliste ». Mélanges Massignon. Institut Français de Damas, III, 1956.

MASSIGNON, L. La Passion de Hallâj. Quatro volumes. Paris: Gallimard, 1975.

.Essai sur les origines du lexique technique de la mystique musulmane. Paris : Éditions du Cerf, 1999.

.Les Trois prières d'Abraham : Éditions du Cerf, 1997.

Parole donnée. Paris : Julliard, 1962

.Akhbar Al-Hallâj, Recueil d'oraisons et d'exhortations du martyr mystique de l'Islam, Paris: J. Vrin, 1975.

Examen du "Présent de l'homme lettré" par Abdallah Ibn AlTorjoman. Roma: Pontificio Istituto di Studi Arabi e d'Islamistica, 1992.

NASCIMENTO, C. A. R. Tratado da Luz de Roberto Grosseteste. Assis: TRAMS/FORM/ACAO, 1974. 
PLATTI, Emilio. « La doctrine des chrétiens d'après Abū 'Īsā al-Warrāq dans son traité sur la Trinité », MIDEO 20. Louvain-Paris : Éditions Peeter, 1991.

. «Islam et Occident : "Choc de théologies" ?» MIDEO 24.

Louvain-Paris : Éditions Peeters, 2000.

. «L'image de l'islam chez le dominicain Vincent de Beauvois » MIDEO 25-26. Louvains-Paris : Éditions Peeters, 2004.

ROSS, W. D. Aristóteles (Tradução de Luiz Felipe FERREIRA). Lisboa: Dom Quixote, 1987.

YOUSIF, Ephrem-Isa. Les Philosophes et Traducteurs Syriaques: d'Athènes à Bagdad. Montréal : L’Harmattan Inc., 1997. 